Universidade de São Paulo

Faculdade de Filosofia, Ciências e Letras de Ribeirão Preto

Departamento de Química

Programa de Pós-Graduação em Química

\title{
"Avaliação de fármacos fotossensíveis derivados da cloro alumínio ftalocianina no tratamento da progressão tumoral em modelo de matriz tridimensional mista"
}

\section{Versão Corrigida}

Priscila da Costa Carvalho de Jesus

Dissertação apresentada à Faculdade de Filosofia, Ciências e Letras de Ribeirão Preto da Universidade de São Paulo, como parte das exigências para a obtenção do título de Mestre em Ciências, Área: Química

RIBEIRÃO PRETO -SP

2012 
Universidade de São Paulo

Faculdade de Filosofia, Ciências e Letras de Ribeirão Preto

Departamento de Química

Programa de Pós-Graduação em Química

\section{“Avaliação de fármacos fotossensíveis derivados da cloro alumínio ftalocianina no tratamento da progressão tumoral em modelo de matriz tridimensional mista"}

\section{Versão Corrigida}

Priscila da Costa Carvalho de Jesus

Dissertação apresentada à Faculdade de Filosofia, Ciências e Letras de Ribeirão Preto da Universidade de São Paulo, como parte das exigências para a obtenção do título de Mestre em Ciências.

Área de conentração: Química

Orientador: Prof. Dr. Antonio Claudio Tedesco

RIBEIRÃO PRETO -SP

2012 
Autorizo a reprodução e divulgação total ou parcial deste trabalho, por qualquer meio convencional ou eletrônico, para fins de estudo e pesquisa, desde que citada a fonte. A versão original encontra-se disponível na Faculdade de Filosofia, Ciências e Letras de Ribeirão Preto.

\section{FICHA CATALOGRÁFICA}

Jesus, Priscila da Costa Carvalho

Avaliação de fármacos fotossensíveis derivados da cloro alumínio ftalocianina no tratamento da progressão tumoral em modelo de matriz tridimensional mista.

Ribeirão Preto, 2012.

$85 \mathrm{f.} ; 30 \mathrm{~cm}$.

Dissertação de Mestrado, apresentada à Faculdade de Filosofia, Ciências e Letras de Ribeirão Preto/USP. Área: Química.

Orientador: Tedesco, Antonio Claudio

1. Ftalocianina. 2. Progressão tumoral. 3. Pele. 


\section{FOLHA DE APROVAÇÃO}

Nome do aluno: Priscila da Costa Carvalho de Jesus

Título do trabalho: Avaliação de fármacos fotossensíveis derivados da cloro alumínio ftalocianina no tratamento da progressão tumoral em modelo de matriz tridimensional mista.

Dissertação de Mestrado apresentada ao Programa de Pós-Graduação em Química para obtenção do Título de Mestre em Ciências.

Área de concentração: Química

Orientador: Prof. Dr. Antonio Claudio Tedesco

Aprovado em:

Banca Examinadora

Prof. Dr.

Instituição:

Assinatura:

Prof. Dr.

Instituição: Assinatura:

Prof. Dr.

Instituição: Assinatura: 
Aos que acreditam e persistem nas suas ideias. 


\section{Agradecimentos}

Aos meus pais Silvana e José Ernesto e ao meu irmão Pedro Henrique por me apoiarem incondicionalmente, dando não somente todo o suporte necessário para que eu pudesse viver de estudar, mas também para que eu pudesse aproveitar essa vivência com todo conforto e carinho.

Ao meu orientador Prof. Dr. Antonio Claudio Tedesco por sempre me guiar e dedicar o seu tempo e sua atenção para a minha formação.

Aos amigos e amigas ICs, mestrandos, doutorandos, pós-doutorandos e outros membros do Laboratório de Fotobiologia e Fotomedicina por estarem presentes no dia-a-dia e também nas festividades, compartilhando vivências, conhecimentos e também momentos de alegria. Agradeço especialmente à Olímpia por sempre ajudar em tudo que foi preciso e pela alegria contagiante.

Às companheiras de experimento Sabrina e Dani Jardim, cuja ajuda, paciência e companheirismo, dentro e fora do laboratório, foram imprescindíveis para a realização deste trabalho.

À recém Profa. Dra. Andreza Simioni e ao Dr. Fernando Lucas Primo pelo apoio e paciência em repassar seus conhecimentos sobre diversas técnicas, sem as quais não seria possível a realização deste trabalho.

À técnica Vani Maria Alves do Laboratório de Histologia do Departamento de Biologia Celular e Molecular e Bioagentes Patogênicos da Faculdade de Medicina de Ribeirão Preto pelo excelente trabalho realizado e pela amizade.

Ao Prof. Dr. Herenilton Paulino Oliveira e à Dra. Aline Bolsoni por me proporcionarem toda bagagem científica durante os anos de Iniciação Científica e também pelo incentivo para que tudo isso se realizasse.

Aos amigos e amigas companheiros de faculdade, de almoços, de churrascos e de todas as horas, aos amigos de longa e "pouca" data, agradeço a cada um pessoalmente por sempre terem me acompanhado na minha jornada.

A todos os meus familiares.

À Universidade de São Paulo e à Faculdade de Filosofia, Ciências e Letras de Ribeirão Preto por todo auxílio durante o curso de mestrado.

À Capes e ao CNPq pela concessão da bolsa de mestrado (148010/2010-5) e pelo suporte financeiro para que a realização dessa pesquisa se tornasse viável. 
"Querem que vos ensine o modo de chegar à ciência verdadeira? Aquilo que se sabe, saber que se sabe; aquilo que não se sabe, saber que não se sabe; na verdade é este o saber."

Confúcio 


\section{RESUMO}

JESUS, P. C. C. Avaliação de fármacos fotossensíveis derivados da cloro alumínio ftalocianina no tratamento da progressão tumoral em modelo de matriz tridimensional mista. 2012. 85 f. Dissertação (Mestrado). Faculdade de Filosofia, Ciências e Letras de Ribeirão Preto - Universidade de São Paulo, Ribeirão Preto, 2012.

O processo de cicatrização cutânea pode ser favorecido pela aplicação de laser de baixa potência, sendo a matriz de colágeno e elastina um substituto dérmico no tratamento de feridas descrita como um sistema adequado na engenharia tecidual em sistemas tridimensionais da pele. Com este intuito, foi elaborado um estudo utilizando o sistema nanoemulsão contendo cloro alumínio ftalocianina (ClAlPc) como o agente fotossensibilizante em biópsias de explants de pele de pacientes saudáveis irradiadas por luz proveniente de laser de baixa potência, visando estabelecer a melhor dose de luz para a bioestimulação de colágeno tipo I e elastina neste tecido. O sistema de liberação de fármacos foi sintetizado utilizando protocolos já conhecidos, cujas propriedades fotoquímicas e fotofísicas foram confirmadas por espectrofotometria de absorção e fluorescência, além de estudos de estabilidade medindo-se o tamanho das partículas, potencial Zeta e índice de polidispersão. Uma vez caracterizado este sistema e conhecendo-se a sua faixa de absorção, elaborou-se um protocolo para avaliar a ação do fármaco nos principais componentes da matriz extracelular, como colágeno e elastina, e a sua ação combinada com luz laser de baixa potência em três doses conhecidas distintas: 70, 140 e $700 \mathrm{~mJ} / \mathrm{cm}^{2}$. Foi avaliada também a ação somente da irradiação sobre as biópsias, nas mesmas doses, podendo-se assim observar os seus efeitos. As estruturas morfológicas da pele foram estudadas por histologia, e posteriormente foram comparadas quantitativamente as porções de colágeno e elastina da pele tratada e irradiada com as amostras do controle, as quais não receberam nenhum tipo de tratamento. Tanto a análise para colágeno tipo I quanto a análise para elastina apontaram um aumento de quase $20 \%$ em relação às amostras não tratadas, utilizando a dose intermediária de $140 \mathrm{~mJ} / \mathrm{cm}^{2}$ nas amostras tratadas com o fármaco de ftalocianina, durante um período de 14 dias após a irradiação. Este efeito foi bastante significativo, ao ser comparado com a ação somente da irradiação, que apresentou desempenho inferior. Outra técnica explorada neste trabalho e utilizada na detecção da expressão das enzimas MMP-2 e MMP-9, participantes do processo cicatricial, foi a zimografia de gelatina, utilizando o meio de cultivo de cada amostra. As bandas relacionadas à degradação da gelatina para cada amostra no zimograma foram quantificadas e os níveis de expressão de MMP-2 e MMP-9 comparados. Os resultados obtidos confirmaram a análise histológica, apontando um maior nível de expressão dessas enzimas nos grupos tratados com o fármaco fotossensibilizante e luz na dose intermediária $\left(140 \mathrm{~mJ} / \mathrm{cm}^{2}\right)$ sendo esta combinação a mais promissora para um estudo mais aprofundado.

Palavras chave: Ftalocianina; progressão tumoral; bioestimulação; colágeno; pele. 


\begin{abstract}
JESUS, P. C. C. Evaluation of photosensitizers aluminum chloride phthalocyanine derivatives in the treatment of tumor progression in three-dimensional matrix. 2012. 85 f. Dissertation (Master). Faculdade de Filosofia, Ciências e Letras de Ribeirão Preto Universidade de São Paulo, Ribeirão Preto, 2012.
\end{abstract}

Wound healing process can be favored by Low Level Laser Therapy, with the collagen and elastin matrix a dermic substitute described as an appropriate system in tissue engineering and in tridimensional skin systems. With this purpose, a study was elaborated using the system nanoemulsion of aluminium-chloride phthalocyanine ( $\mathrm{ClAlPc})$ as photosensitizer in skin biopsies obtained after plastic surgery and irradiated by a low level laser, to establish the most appropriate dose of light for biostimulation of type I collagen and elastin fibers. The drug delivering system was synthesized using a well-known protocol and its photophysical and photochemical properties were confirmed by absorption and fluorescence spectrophotometry, besides stability studies measuring particle size, zeta potential and polidispersion index. Once characterized this system and known its absorption range in the UV-Vis region of light spectrum, a protocol was elaborated for evaluating the effect of the photosensitizer direct into extracellular matrix components, collagen and elastin, and the combined effect with low level laser therapy using three different doses: 70, 140 and 700 $\mathrm{mJ} / \mathrm{cm}^{2}$. Also, only the effect of irradiation was evaluated using the same doses. Morphological structures of the skin were analyzed by histology, and portions of collagen and elastin of skin biopsies after the photosensitizer and light treatment were quantified and compared to the non-treated samples. The analysis for type I collagen and elastin pointed an increase of more than $20 \%$ compared to the non-treated samples, for the samples treated with the combination phosensitizer/light $140 \mathrm{~mJ} / \mathrm{cm}^{2}$ after 14 days of treatment. This effect was significant when compared to the effect of the irradiation only. Another technique was used in this work to detect the expression of MMP-2 and MMP-9, participant enzymes in various processes including tumoral progression and wound healing. Samples of biopsies culture medium were collected and analyzed by gelatin zymography, the bands related to gelatin degradation were quantified and MMP-2 and MMP-9 expression levels compared. The obtained results confirmed histological analysis, pointing a higher expression level of these enzymes for the group treated with the photosensitizer and the intermediate dose of light (140 $\mathrm{mJ} / \mathrm{cm}^{2}$ ), leading to a promising combination of treatment for future studies.

Key words: Phthalocyanine; nanoemulsion; biostimulation; collagen; skin. 


\section{LISTA DE FIGURAS}

Figura 1. Estruturas moleculares de alguns agentes fotossensibilizantes aprovados clinicamente ou em andamento

Figura 2. Estrutura molecular da ftalocianina

Figura 3. Esquema das camadas da pele e estruturas anexas

Figura 4. Janela óptica no tecido. Espectros de absorção de importantes cromóforos do tecido, como água, oxi e desoxihemoglobina e melanina, plotados em escala logarítmica..... 18

Figura 5. Representação esquemática das camadas da pele e as suas propriedades ópticas. As setas indicam o caminho da luz pelos tecidos da pele.

Figura 6. Propagação da luz pelos tecidos

Figura 7. Corte da pele com o instrumento punch, evidenciando as suas três camadas: epiderme, derme e hipoderme.

Figura 8. Principais etapas do experimento com biópsias de explants de pele: A) Fragmento de pele humana mantido em meio DMEM para realização do corte das biópsias; B) Biópsias de pele cortadas utilizando o punch e mantidas em meio DMEM; C) Placas de Petri contendo o gel de colágeno e as biópsias de pele; D) Irradição das placas com laser de $670 \mathrm{~nm}$ após tratamento com cloro alumínio ftalocianina.

Figura 9. Marcação (verde) da rede de elastina (vermelho) de uma amostra de imagem, utilizando o software AxioVision Release 4.8.2 da Carl Zeiss acoplado ao microscópio óptico.

Figura 10. Etapas do processo de zimografia: A) Montagem dos géis; B) Amostras aplicadas no gel inserido na cuba de corrida; C) Revelação dos géis com solução de Azul de Coomassie; D) Gel finalizado.

Figura 11. A) Imagem obtida de um gel de zimografia utilizando-se o sistema de aquisição de imagens com câmara ultravioleta; B) Imagem com inversão de pixels. 
Figura 12. Estudo de estabilidade físico-química monitorando-se o tamanho médio das gotículas, o índice de polidispersão (A) e o potencial Zeta (B) em função do tempo para a nanoemulsão contendo ClAlPc. Os resultados são expressos como média \pm desvio padrão ... 47

Figura 13. (A) Espectro de absorção na região do UV-Vis da solução de ClAlPc em acetonitrila, (B) Curva de calibração da ClAlPc em acetonitrila, Absorbância $=0.3829 \mathrm{X}$ [ClAlPc, concentração em $\mu \mathrm{g} \mathrm{mL}^{-1}$ ] + $0.0126(\mathrm{R}=0$,9992) (SIQUEIRA-MOURA et al., 2010) e (C) Espectro de fluorescência da solução de ClAlPc em acetonitrila (SIQUEIRAMOURA et al., 2010).

Figura 14. Análise histológica da biópsia de explant de pele sem tratamento (controle) e corada com Orceína, evidenciando as camadas da pele: epiderme e derme.

Figura 15. Molécula de Orceína

Figura 16. Comparação entre as porcentagens de área de elastina das biópsias de pele irradiadas por laser de diodo $(670 \mathrm{~nm})$ em diferentes doses de 70,140 e $700 \mathrm{~mJ} / \mathrm{cm}^{2}$ e incubadas por diferentes períodos: A) 7 dias; B) 14 dias. Os resultados são expressos como média \pm desvio padrão, sendo *** $(\mathrm{P}<0,001)$, ** $(\mathrm{P}<0,01)$ e * $(\mathrm{P}<0,05)$ estatisticamente significativos.

Figura 17. Comparação entre as porcentagens de área de elastina das biópsias de pele tratadas com a nanoemulsão contendo ClAlPc, irradiadas por laser de diodo $(670 \mathrm{~nm}) \mathrm{em}$ diferentes doses de 70, 140 e $700 \mathrm{~mJ} / \mathrm{cm}^{2}$ e incubadas por diferentes períodos: A) 7 dias; B) 14 dias. Os resultados são expressos como média \pm desvio padrão, sendo *** $(\mathrm{P}<0,001)$ estatisticamente significativos

Figura 18. Molécula Direct Red 80 (Sirius Red, Picrosirius Red).....

Figura 19. Rota biosintética para formação de fibras de colágeno tipo I, principal componente estrutural da pele.

Figura 20. Análise histológica das biópsias de pele tratadas com ClAlPc, irradiadas pr laser de diodo $(670 \mathrm{~nm})$ em diferentes doses, coradas por Picrosirius Red e visualizadas por microscopia de campo claro (objetiva de 20x). A primeira sessão apresenta as amostras tratadas por 7 dias e a segunda apresenta as amostras tratadas por 14 dias após a irradiação. 
Figura 21. Comparação entre as porcentagens de área de colágeno tipo I das biópsias de pele irradiadas por laser de diodo $(670 \mathrm{~nm})$ em diferentes doses de 70,140 e $700 \mathrm{~mJ} / \mathrm{cm}^{2} \mathrm{e}$ incubadas por diferentes períodos: A) 7 dias; B) 14 dias. Os resultados são expressos como média \pm desvio padrão, sendo * $(\mathrm{P}<0,05)$ estatisticamente significativo.

Figura 22. Comparação entre as porcentagens de área de colágeno tipo I das biópsias de pele tratadas com ClAlPc, irradiadas por laser de diodo $(670 \mathrm{~nm})$ em diferentes doses de 70, 140 e $700 \mathrm{~mJ} / \mathrm{cm}^{2}$ e incubadas por diferentes períodos: A) 7 dias; B) 14 dias. Os resultados são expressos como média \pm desvio padrão

Figura 23. Comparação entre o aumento da porcentagem de área de colágeno tipo I em relação ao controle, sendo G3, G4 e G5 as amostras tratadas com a cloro alumínio ftalocianina e irradiadas com as respectivas doses 70,140 e $700 \mathrm{~mJ} / \mathrm{cm}^{2}$. A) 7 dias; B) 14 dias. Os resultados são expressos como média \pm desvio padrão

Figura 24. Conjunto dos géis 1 e 4 de zimografia, respectivos às amostras tratadas por 7 e 14 dias

Figura 25. Conjunto dos géis 2 e 5 de zimografia, respectivos às amostras tratadas por 7 e 14 dias.

Figura 26. Conjunto dos géis 3 e 6 de zimografia, respectivos às amostras tratadas por 7 e 14 dias

Figura 27. Atividade gelatinolítica detectada por zimografia dos meios de cultura coletados após experimento com biópsias de explants de pele cultivadas em gel de colágeno, expressa em porcentagem de expressão de MMP-9 em relação à amostra do controle. A) 7 dias; B) 14 dias. Os resultados são expressos como média \pm desvio padrão. ... 69

Figura 28. Atividade gelatinolítica detectada por zimografia dos meios de cultura coletados após experimento com biópsias de explants de pele cultivadas em gel de colágeno, expressa em porcentagem de expressão de MMP-2 em relação à amostra do controle. A) 7 dias; B) 14 dias. Os resultados são a média \pm desvio padrão

Figura 29. Parte da cascata proteolítica mostrando a ativação da progelatinase $B$ em gelatinase $\mathrm{B}$ 
Figura 30. Estrutura esquemática da MMP-2 e da MMP-9, evidenciando os seus principais domínios e a região catalítica.

Figura 31. Gelatinases A e B (MMP-2 e MMP-9, respectivamente), mostrando alguns dos seus domínios 


\section{LISTA DE TABELAS}

Tabela I. Nomenclatura das amostras de meio de cultura recolhidas após o experimento com biópsias de explants de pele e utilizadas nos estudos por zimografia

Tabela II. Ordem das amostras nos géis de zimografia segundo nomenclatura estabelecida.

Tabela III. Parâmetros físico-químicos para a nanoemulsão contendo ClAlPc 


\section{LISTA DE SÍMBOLOS, SIGLAS E ABREVIATURAS}

ALA Ácido aminolevulínico

5-ALA Ácido 5-aminolevulínico

CT Controle

DMEM "Dubleco Eagle's Minimum Essential Medium"

EROs Espécies reativas de oxigênio

He-Ne Hélio-Neônio

HpD Derivado da hematoporfirina

HT-1080 Linhagem de células de fibrossarcoma humano

IPd Índice de polidispersão

LED "Light Emiting Diode"

LLLT Terapia com laser de baixa potência

MAL Ácido aminolevulínico

MEC Matriz extracelular

MMP Metaloprotease

MMP- $a \quad$ Metaloprotease ativa

MMP- $p \quad$ Pró-metaloproease

NADH Nicotinamida adenina dinucleotídeo

Nd:YAG Neodínio dopado com "yttrium aluminum garnet $\left(\mathrm{Y}_{3} \mathrm{Al}_{5} \mathrm{O}_{12}\right)$ "

NE Nanoemulsão

${ }^{1} \mathrm{O}_{2} \quad$ Oxigênio singlete

$\mathrm{O}_{2} \bullet \quad$ Oxigênio radicalar

$\mathrm{OH} \bullet \quad$ Radical hidroxila 
PMN Leucócitos polimorfonucleares

PpIX Protoporfirina IX

Redox Redução-oxidação

Rpm Rotações por minuto

SDS Dodecil sulfato de sódio

TEMED N,N,N,N-tetrametil etileno diamina

TFD Terapia Fotodinâmica

UV-Vis Ultravioleta-visível 


\section{SUMÁRIO}

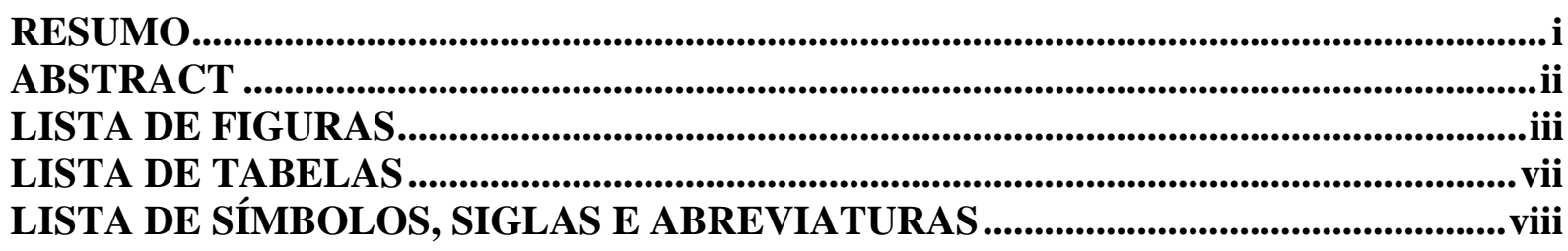

\section{INTRODUÇÃO}

1.1 A Laserterapia e os Processos Fotodinâmicos.................................................................... 1

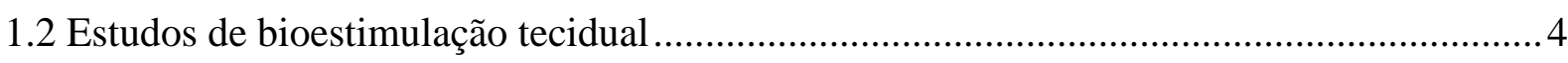

1.3 A escolha do agente fotossensibilizante: Cloro Alumínio Ftalocianina ..............................

$1.4 \mathrm{O}$ sistema de liberação de fármacos: nanoemulsão ....................................................... 12

1.5 A pele e a penetração da luz no tecido ....................................................................... 15

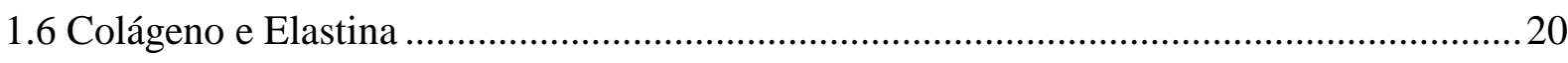

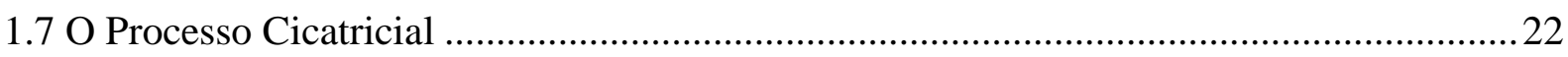

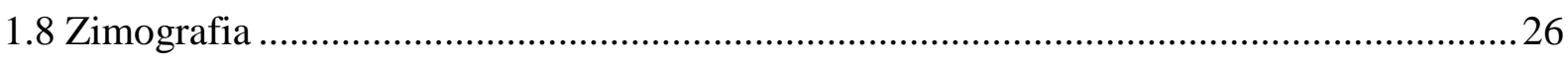

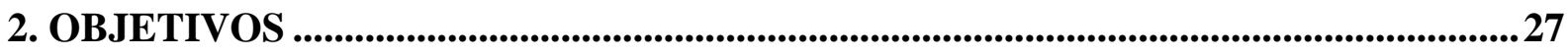

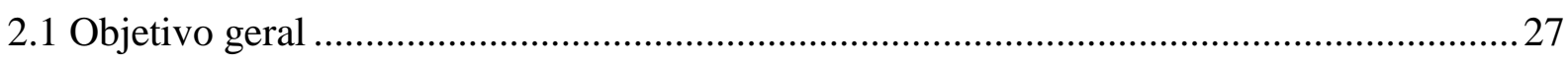

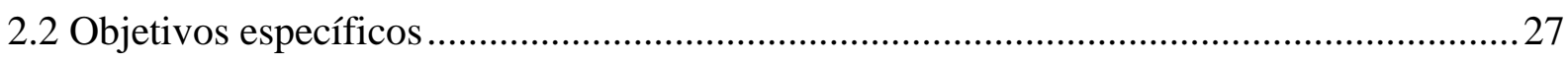

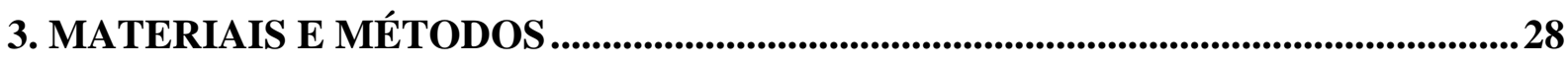

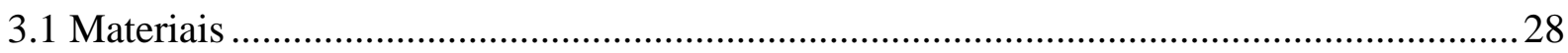

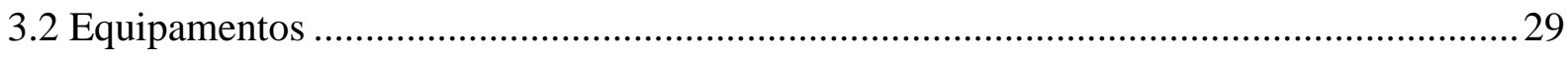

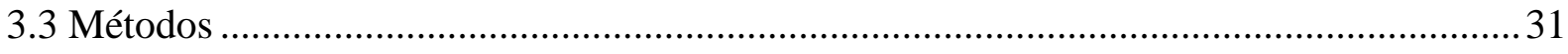

3.3.1 Preparação do sistema de liberação de fármacos: nanoemulsão .................................... 31

3.3.2 Caracterização físico-química da nanoemulsão contendo ClAlPc ................................. 31

3.3.2.1 Determinação do tamanho das gotículas, índice de polidispersão e potencial Zeta..... 31

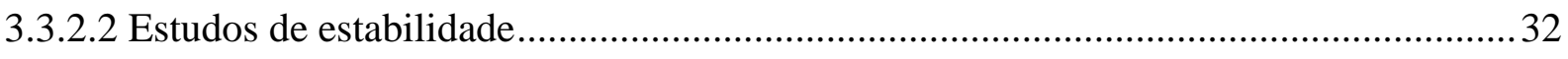

3.3.2.3 Doseamento da ClAlPc na nanoemulsão............................................................... 32

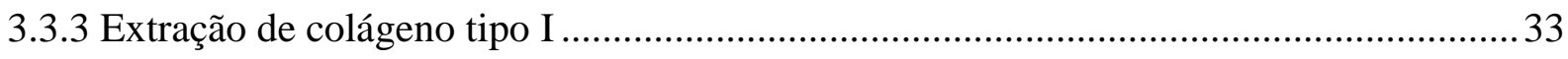

3.3.4 Preparação das biópsias de explants de pele e dos géis de colágeno ............................. 33

3.3.5 Tratamento com a formulação de ftalocianina e irradiação das placas ........................... 36

3.3.6 Fixação das biópsias e análise histológica.................................................................... 37

3.3.7 Doseamento de colágeno e elastina nas biópsias de explants de pele ..............................39 
3.3.8 Avaliação da expressão de enzimas MMP-2 e MMP-9 por zimografia 40

3.3.9 Quantificação dos géis de zimografia.......................................................................... 43

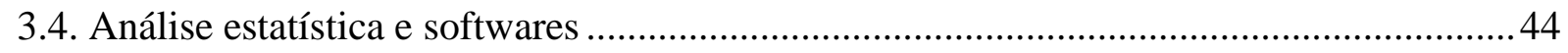

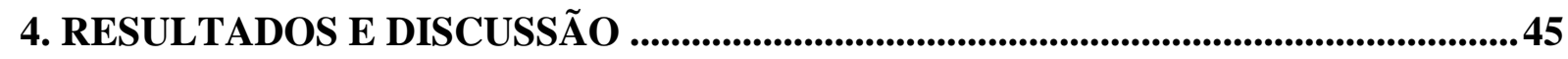

4.1 Determinação do tamanho de gotículas, índice de polidispersão e potencial Zeta da

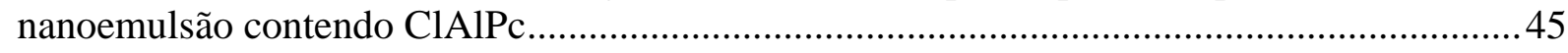

4.2 Estudo de estabilidade termodinâmica da nanoemulsão contendo ClAlPc........................46

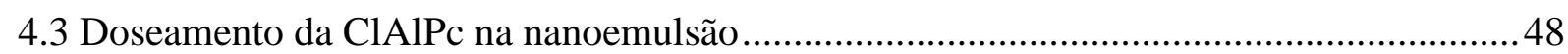

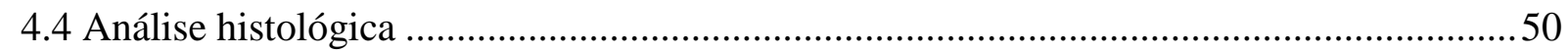

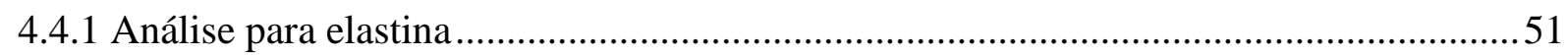

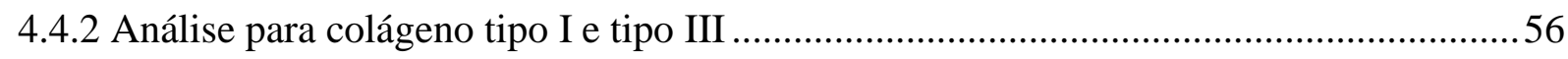

4.5 Avaliação da expressão de enzimas MMP-2 e MMP-9 por zimografia..............................66

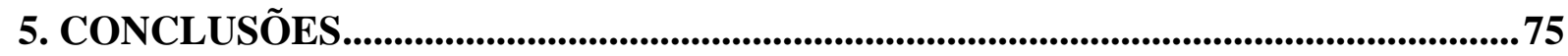

6. REFERÊNCIAS BIBLIOGRÁFICAS ............................................................................ 77 


\section{Introdução}

\subsection{A Laserterapia e os Processos Fotodinâmicos}

Considerando o uso da luz em aplicações para diversas doenças, duas terapias têm sido extensamente estudadas desde a descoberta dos benefícios da aplicação de luz no campo da medicina: Terapia Fotodinâmica (TFD) e Terapia com laser de baixa potência (LLLT - do inglês Low Level Laser Therapy) (AGOSTINIS et al., 2011; CASTANO , DEMIDOVA e HAMBLIN, 2004; LAVI et al., 2003; LUBART et al., 2005; ZHANG et al., 2003). A TFD tem sido utilizada para tratamento de diversas doenças oncológicas, dermatológicas e oftálmicas (SIQUEIRA-MOURA et al., 2010). Além dessas aplicações, a TFD atua em outras áreas clínicas, como tratamento alternativo de artrite reumatoide (TRAUNER e HASAN, 1996), degeneração macular (AHMAD et al., 2008) e aterosclerose (PARK et al., 2010). Atualmente vem sendo muito explorada também nos tratamentos estéticos para fotorejuvenescimento e acne (BISSONNETTE, 2011; COLIC et al., 2004).

Ela pode ser definida como a administração de uma droga ou corante não-tóxico, conhecido como um fármaco fotossensibilizante, seguida pela irradiação com luz visível na região que contém a lesão, que na presença de oxigênio leva à geração de espécies citotóxicas e consequentemente à morte celular (AGOSTINIS et al., 2011; DOUGHERTY, 1984; SIMIONI, A. R., 2009; TEDESCO , ROTTA e LUNARDI, 2003). A recente explosão de interesse na TFD data da descoberta dos derivados da hematoporfirina (HpD) por Lipson e Baldes em 1960 (LIPSON, BALDES e OLSEN, 1961).

O uso clínico da TFD em pacientes com câncer data do final da década de 1970, quando foram publicados os primeiros estudos dos efeitos da $\mathrm{HpD}$ com luz em 5 pacientes com câncer na bexiga. Em 1975, Dougherty et al (DOUGHERTY et al., 1975) relataram a 
primeira série de estudos de pacientes tratados com sucesso pela TFD usando HpD. Da grande variedade de tumores avaliados, todos manifestaram alguma resposta ao tratamento. Desde esse trabalho, foram relatados mais de 200 ensaios clínicos para o uso da TFD, incluindo em tumores na pele, cabeça e pescoço, sistema digestivo, sistema urinário (próstata e bexiga), cérebro, entre outras aplicações (AGOSTINIS et al., 2011).

A TFD é um processo de basicamente dois estágios. Após a administração do agente fotossensibilizante, os locais dos tumores são irradiados com luz num comprimento de onda apropriado. A luz pode chegar virtualmente a qualquer órgão do corpo por meio de dispositivos de fibra-óptica flexível. A seletividade é derivada da capacidade dos agentes fotossensibilizantes de se localizarem nas lesões neoplásicas e do caminho da luz diretamente sobre os locais afetados. Paradoxalmente, a natureza altamente localizada da TFD é uma das suas limitações, pois o tratamento não é efetivo contra lesões metastáticas, as quais são as causas mais frequentes de morte de pacientes com câncer (AGOSTINIS et al., 2011) (BARBUGLI, P. A., 2010; NUNES, S. M. T., 2003; PRIMO, F. L., 2009; SIMIONI, A. R., 2009; TAMIETTI et al., 2007; TEDESCO , ROTTA e LUNARDI, 2003).

O fármaco fotossensibilizante ou a luz isoladamente apresentam pouca ou até nenhuma citotoxicidade para o tecido nas condições ideais. O mecanismo de regressão fotoinduzida do tumor na TFD frequentemente está associado à participação do oxigênio singlete gerado, aos processos fotoativados de transferência eletrônica e abstração de hidrogênio do fármaco no estado excitado e à formação de outras espécies radicalares. As espécies reativas de oxigênio $\left({ }^{1} \mathrm{O}_{2}, \mathrm{O}_{2} \bullet, \mathrm{OH} \bullet\right.$, denominadas EROs), quando geradas no meio biológico, agem nos centros específicos dos sistemas celulares, desencadeando a morte dos tecidos por processos de necrose e/ou apoptose celular (SOBOLEV, JANS e ROSENKRANZ, 2000) e a presença dos fotossensibilizadores neste meio é capaz de potencializar a produção destas espécies reativas (FERREIRA, D. M., 2012). 
O principal mecanismo possível para a fotossensibilização é a transferência de energia para o oxigênio molecular a partir da configuração eletrônica triplete do fármaco, induzindo a formação do oxigênio singlete $\left({ }^{1} \mathrm{O}_{2}\right)$. O oxigênio singlete é uma espécie altamente reativa que interage de forma a oxidar vários substratos biológicos resultado da sua interação por difusão molecular. Acredita-se que o oxigênio singlete seja o principal mediador dos efeitos fotodinâmicos nos sistemas biológicos, pois reage rápida e indiscriminadamente com os mais variados alvos eletrofílicos, como lipídios insaturados, proteínas, ácidos, entre outros (PRIMO, F. L., 2009).

Quase uma década após a descoberta dos derivados da hematoporfirina, Mester et al (MESTER et al., 1971) constataram que baixas doses de laser estimularam a regeneração de não somente feridas induzidas mecanicamente, mas também de queimaduras. $\mathrm{O}$ mecanismo de interação do laser a nível molecular foi descrito primeiramente por Karu em 1988 (KARU, 1988). Os incrementos de ATP mitocondrial que se produzem após a irradiação por laser favorecem um grande número de reações que interferem no metabolismo celular. Em estados patológicos, o laser interfere no processo de troca iônica, acelerando o incremento de ATP (KARU, 1988). Desde então, LLLT vem sendo aplicada em diversas condições médicas, tais como o reparo de feridas e outras doenças dermatológicas, dano neurológico, tratamento da dor e inflamação, entre outras (ZHANG et al., 2003; LAVI et al., 2003; LUBART et al., 2005; PAL et al., 2007; PRIMO, F. L., 2009; RIEKKI et al., 2000; SIMIONI, A. R., 2009; ZANCANELA et al., 2011).

A terapia com laser de baixa potência (LLLT) envolve a interação de uma luz monocromática de baixa potência com sistemas biológicos, com o intuito de iniciar efeitos biomodulativos. A exposição a laser de baixa potência produziu ambos efeitos estimulante e inibitório, in vitro e in vivo, dependendo da dose de energia (fluência). Para as aplicações in vivo, efeitos da LLLT foram observados para o tratamento de feridas, regeneração do nervo 
central e periférico, tratamento de úlceras do estômago e duodenais (DAMS et al., 2011; JAYASREE et al., 2001). Nos estudos in vitro a nível celular, LLLT alterou a expressão gênica, a proliferação celular, o balanço do $\mathrm{pH}$ intercelular, o potencial de membrana mitocondrial, a geração de espécies reativas de oxigênio, nível de íons cálcio, gradiente de prótons e consumo de oxigênio (ALEXANDRATOU et al., 2002; ZANCANELA et al., 2011; LAVI et al., 2003). Por outro lado, um efeito inibitório foi observado em doses maiores de energia. A irradiação de luz em comprimentos de onda de 630, 632,8 e $820 \mathrm{~nm}$ acelerou a síntese de ATP em células de adenocarcinoma e em células de linfócitos periféricos (JAYASREE et al., 2001).

Por atuarem por mecanismos diferentes, as aplicações dessas duas terapias (LLLT e TFD) são diferentes, como foi relatado. Porém, considerando a seletividade e os ótimos resultados relatados até o momento com o uso da TFD seria possível utilizar a TFD em estudos de bioestimulção, buscando melhores efeitos do que os já alcançados com a LLLT. A administração do agente fotossensibilizante, tanto topicamente quanto sistemicamente, seguida da irradiação de feridas com luz visível em comprimentos de onda apropriados de modo a excitar ao máximo o fármaco, podem oferecer um tratamento promissor para promover a regeneração de tecidos, especialmente de feridas crônicas, como úlceras, por também possuir uma ação antimicrobiana (PEPLOW , CHUNG e BAXTER, 2012).

\subsection{Estudos de bioestimulação tecidual}

A cicatrização de feridas é um processo natural para manter a integridade da pele e do epitélio daqueles que se submeteram a cirurgia, ou que têm diabetes ou simplesmente que sofreram uma lesão (COULOMB e DUBERTRET, 2002; GUNGORMUS e AKYOL, 2009). Vários métodos foram adotados para aprimorar o processo de tratamento de feridas em 
pacientes afetados por diferentes tipos de feridas. Houve inúmeros relatos indicando o uso potencial da irradiação por laser de baixa potência no tratamento de feridas abertas tanto de animais quanto em ensaios clínicos (JAYASREE et al., 2001).

Diversas teorias emergiram para explicar as mudanças bioquímicas transientes e permanentes devido à ação de baixas doses de luz sobre a pele (ALEXANDRATOU et al., 2002; LUBART et al., 2005; MESTER et al., 1971; PEPLOW , CHUNG e BAXTER, 2012). Literatura abrangendo a ação estimulante e inibitória da luz azul e vermelha sobre células de bactérias e de mamíferos foi revisada. Estudos sugeriram que um fotoaceptor para estimulação do metabolismo celular é a enzima terminal da cadeia respiratória (citocromo-c oxidase para células eucarióticas). Na região azul do espectro visível, flavoproteínas como as NADH-dehidrogenase podem atuar também como fotoaceptores. A sugestão de que a citocromo-c oxidase é uma molécula aceptora foi confirmada por experimentos com neurônios primários funcionalmente inativados, propondo que a luz regula essa enzima (KARU e KOLYAKOV, 2005).

Foi proposto que dois processos estão envolvidos durante a interação luz-célula. Um deles é a aceleração da transferência de elétrons entre pares redox em algumas sessões da cadeia respiratória (KARU e KOLYAKOV, 2005), e o outro a transferência de energia de excitação para oxigênio molecular, resultando na formação de EROs (PRIMO, F. L., 2009). Suspeita-se que o processo formador domina quando se utiliza doses baixas de energia, produzindo bioestimulação, enquanto o dano fotodinâmico ocorre quando se utiliza doses maiores de energia (PAL et al., 2007; PRIMO et al., 2011; SIMIONI, A. R., 2009).

Diversas fontes de luz têm sido avaliadas como um tratamento não invasivo em feridas, como lasers, LEDs e a luz monocromática propriamente dita (HU et al., 2007; PRIMO et al., 2008). Diferentes tipos de lasers foram identificados por produzirem efeitos biológicos benéficos, incluindo os lasers de Argônio, Hélio-Neônio (He-Ne), Arseneto de 
gálio e alumínio (GaAlAs), Arseneto de gálio (GaAs) e Nd:YAG. Esse efeito chamado de “fotoestimulação" ou "bioestimulação" produz efeitos não destrutivos em tecidos no nível celular. Bioestimulação tem sido usada para uma variedade de terapias médicas, como no tratamento de feridas e no controle da dor, assim como em pesquisa científica básica. Os resultados da bioestimulação mostraram aumentar a atividade celular durante o tratamento de feridas. Alguns dos efeitos da bioestimulaçao que podem influenciar no tratamento de feridas foram realizados por ensaios in vitro, incluindo a proliferação de fibroblastos, síntese de colágeno, estimulação de macrógafos e uma maior taxa de produção da matriz extracelular (GUNGORMUS e AKYOL, 2009).

Estudos evidenciaram que o tratamento com laser He-Ne em lesões cutâneas e peritoneais iria acelerar o processo de cicatrização de feridas (HU et al., 2007). A irradiação por laser em feridas abertas também pode estimular a replicação de fibroblastos. Foi sugerido que a irradiação por laser de baixa potência estimula a regeneração da pele por induzir a atividade mitótica das células epiteliais. Por não ser observado nenhum aumento de temperatura durante a irradiação por laser de He-Ne, efeitos a nível celular são considerados mais bioquímicos do que térmicos. Além disso, nenhum estresse é esperado durante a irradiação (DAMS et al., 2011).

Um estudo (LUBART et al., 2005) sugeriu que diminuindo a dose de luz laser suficientemente para aplicação da TFD poderia causar um efeito bioestimulatório nas células, similar ao que acontece com a laserterapia a baixa potência. Além disso, células enriquecidas com pequenas quantidades de fármaco podem proliferar melhor após a irradiação com laser, devido às baixas concentrações de EROs geradas (PEPLOW, CHUNG e BAXTER, 2012). Em um estudo (JAYASREE et al., 2001), o efeito da TFD no tratamento de feridas foi avaliado utilizando lasers que mostraram ser efetivos para bioestimulação. Os resultados sugeriram que a TFD acelera o processo de cicatrização de feridas em ratos, utilizando 
combinações de fármaco e luz como ALA e laser de He-Ne e HpD e combinação dos lasers He-Ne e Nd:YAG.

Estudos dos efeitos combinados do uso de um fármaco fotossensibilizante e irradiação a laser em feridas causadas experimentalmente em ratos são importantes para o entendimento do processo de cicatrização envolvido após a TFD. Quando TFD é usada para estimular a cicatrização de feridas é importante minimizar o dano nos tecidos intactos, e isso pode ser dependente da dose e da concentração do fármaco utilizado. Alguns estudos pré-clínicos demonstraram que a fração do tumor para o tecido normal danificado após a TFD está relacionada com a concentração do fármaco, irradiância do laser e intervalo de tempo entre a administração da droga e a irradiação (SITNIK e HENDERSON, 1998; GARCIA et al., 2010).

Um estudo de revisão (PEPLOW , CHUNG e BAXTER, 2012) apontou uma variedade de fármacos utilizados em diversos estudos sobre modulação fotodinâmica, publicados nos últimos 5 anos. Dentre os fármacos testados, em diferentes doses, incluem feoforbídeo a, hematoporfirina, benzoporfirina, PpIX, "Photofrin", 5-ALA, ácido metilaminolevulínico (MAL), cloro alumínio ftalocianina (ClAlPc), cloro alumínio ftalocianina sulfonada (CASPc), 8-bromo ftalocianina de zinco ( $\mathrm{ZnPcBr}[8])$, entre outros.

Outros estudos (PRIMO, F. L., 2009) indicaram que as células em cultura expostas à TFD apresentaram, na maioria, efeito inibitório, refletido no decréscimo do crescimento e viabilidade celular. Os modelos celulares mais apropriados incluíram fibroblastos de diabéticos, fibroblastos de feridas e células cultivadas numa matriz sintetizada por outras células. Em TFD, a irradiação das células com doses baixas de energia, ou irradiação das células enriquecidas com pequenas quantidades de fármaco fotossensibilizante podem estimular a sua proliferação. Constatou-se que a TFD em feridas cutâneas pode levar a uma melhora nos resultados de tratamento, comparando-se aos efeitos do tratamento realizado 
somente com luz. Apesar dos resultados promissores, outros estudos são requeridos utilizando modelos animais mais sensíveis a alterações no processo de cicatrização de feridas, e que mimetizem melhor o processo de cicatrização em humanos, o qual envolve principalmente os processos de re-epitalização e granulação do tecido em formação (GARCIA et al., 2010; PEPLOW , CHUNG e BAXTER, 2012).

Em outros estudos (SZEIMIES et al., 2012; BISSONNETTE, 2011), a TFD foi examinada para tratamento de câncer do tipo não melanona e tratamento para o fotoenvelhecimento em ensaios clínicos. Foram avaliados os efeitos clínicos da aplicação da TFD utilizando o fármaco MAL no tratamento da pele severamente fotodanificada da face de pacientes. Este tratamento demonstrou excelentes efeitos cosméticos, sustentando a indução da formação de colágeno na derme.

Em trabalho prévio do grupo (SIMIONI, A. R., 2009) foram feitos estudos de estimulação tecidual em pele humana. Foi testado o fármaco silício-naftalocianina em formulação lipossomal e posterior irradiação com laser de $670 \mathrm{~nm}$ nas doses de $0,5,1,3$ e $5 \mathrm{~J} / \mathrm{cm}^{2}$ em biópsias de pele. Esses estudos deram início a uma nova vertente de estudos e aplicações dos processos fotodinâmicos voltada especificamente para o uso dos processos de fotobioestimulação aplicados aos processos de remodelagem cutânea.

O tratamento com TFD requer por definição que os parâmetros de luz e fármaco sejam utilizados simultaneamente numa escala temporal definida. Para o primeiro, parâmetros importantes para estudos in vivo incluem o tempo de aplicação da irradiação utilizada, número de aplicações, o tempo de exposição, além da rota de administração e a dose utilizada. No caso da irradiação com luz, parâmetros físicos importantes são: comprimento de onda, área irradiada, potência, densidade de potência, energia, densidade de energia e frequência da irradiação se o sistema laser utilizado for pulsado (AGOSTINIS et al., 2011). Contudo, a relevância desses parâmetros nos efeitos de tratamento por TFD em feridas cutâneas e as suas 
condições ainda permanecem incertas. A escolha do fármaco fotossensibilizante, da fonte de luz e os parâmetros para o tratamento com TFD podem variar consideravelmente em diferentes ensaios clínicos e experimentos com animais.

\subsection{A escolha do agente fotossensibilizante: Cloro Alumínio Ftalocianina}

As características de um fármaco fotossensibilizante ideal já foram discutidas em diversos estudos, e incluem baixos níveis de toxicidade no escuro, tanto em humanos quanto em animais experimentais, e baixa incidência de toxicidade administrativa (como hipotensão e reação alérgica) (CHATTERJEE , FONG e ZHANG, 2008; MACAROFF et al., 2006). O agente fotossensibilizante deve absorver luz em comprimentos de onda da região do vermelho até comprimentos de onda mais longos com o intuito de penetrar no tecido. Ele deve possuir coeficiente de absortividade molar relativamente alto para minimizar a dose de fármaco necessária para alcançar os efeitos desejados. O fármaco fotossensibilizante deve ser um composto puro, com uma composição constante e idealmente solúvel em água ou solúvel numa mistura com solvente parcialmente miscível em água. Além disso, ele não deve agregar em ambientes biológicos, já que isso reduz a sua eficiência fotoquímica (CASTANO , DEMIDOVA e HAMBLIN, 2004).

Os primeiros agentes fotossensibilizantes foram derivados da hematoporfirina e já foram previamente descritos (LIPSON , BALDES e OLSEN, 1961). Muitos estudos foram realizados utilizando um agente fotossensibilizante de primeira geração, como hematoporfirina, 5-ALA, Photofrin, entre outros (DOUGHERTY et al., 1975). Agentes fotossensibilizantes de segunda geração, como as ftalocianinas e as clorinas, foram introduzidos na Terapia Fotodinâmica no âmbito da pesquisa e em ensaios clínicos (NUNES , SGUILLA e TEDESCO, 2004; PRIMO et al., 2007; SIQUEIRA-MOURA et al., 2010; 
TEDESCO , ROTTA e LUNARDI, 2003; PARK et al., 2010; SILVA , SIMIONI e TEDESCO, 2011). Até o momento, diversos sistemas com ftalocianina, como a ftalocianina de silício e de zinco, já estiveram em alguns ensaios clínicos (LUNARDI, ROTTA e TEDESCO, 2007; OLIVEIRA et al., 2005; PRIMO et al., 2008; YANIK et al., 2009). A Figura 1 apresenta as estruturas moleculares de alguns agentes fotossensibilizantes estudados clinicamente.

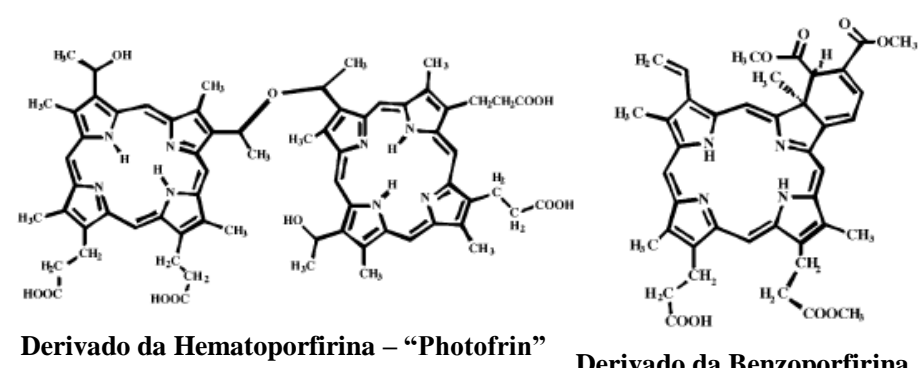

Derivado da Benzoporfirina - BPDMA, "Verteporphin"
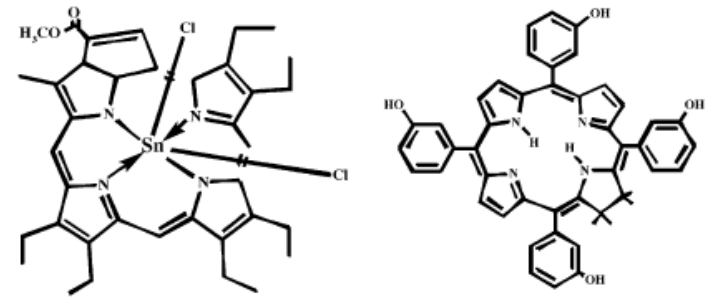

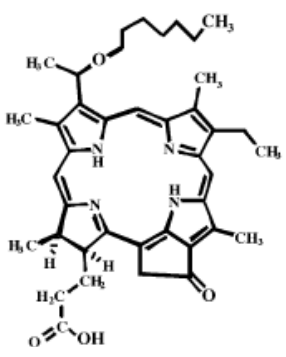

6-éter-pirofeorfobídeo - HPPH

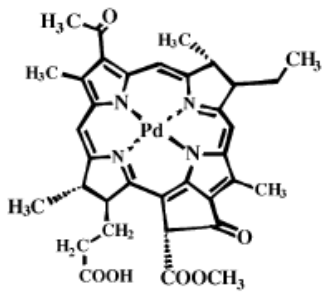

SnEt2 - "Purlytin" m-Tetrahidróxifenil clorina - "Foscan" Bacterioclorina de paládio - "Tookad"

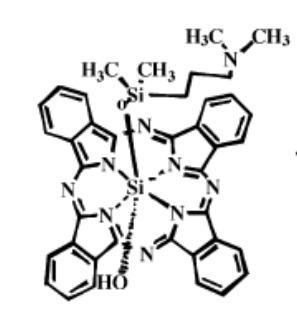

Ftalocianina de silício "PC4"

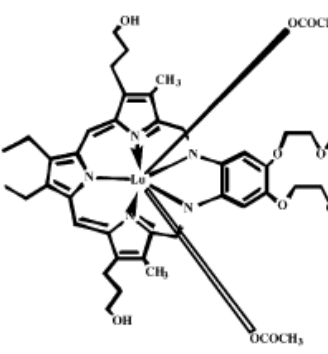

Texafrin lutécio "Lutex"

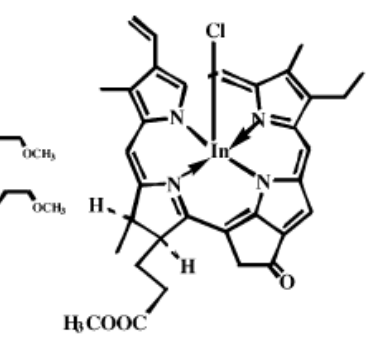

Pirofeoforbídeo de índio MV6401

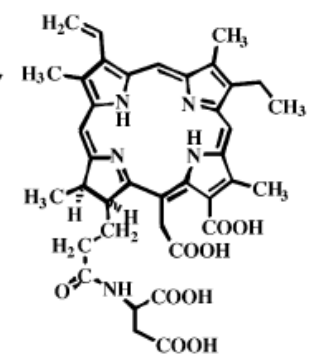

Monoaspartil clorina (e6) LS11, NPe6

Figura 1. Estruturas moleculares de alguns agentes fotossensibilizantes aprovados clinicamente (adaptado de CASTANO, DEMIDOVA e HAMBLIN, 2004).

Ftalocianinas possuem um importante papel na tecnologia moderna, com aplicações em diversos campos, além de terem sido utilizadas como drogas fototóxicas na medicina. A complexação de ftalocianinas com íons metálicos influencia nas suas propriedades fotofísicas. Sabendo da sua forte absorção em comprimentos de onda longos, alta eficiência em gerar 
espécies reativas de oxigênio e facilidade de modificação química, as ftalocianinas emergiram como agentes fotossensibilizantes de segunda geração promissores para Terapia Fotodinâmica (TFD). Durante a última década, um número substancial de agentes fotossensibilizantes baseados em ftalocianinas foram preparados e foi avaliada a sua atividade fotodinâmica, com foco nas análogas de silício, zinco e alumínio, como resultado das suas propriedades fotofísicas desejadas (YANIK et al., 2009).

Estudos demonstraram que essa classe de agentes fotossensibilizantes possuem propriedades fotoquímicas e fotofísicas melhores, como indicado pela ativação em comprimentos de onda maiores (pico de absorção em $680 \mathrm{~nm}$ ), quando comparados, por exemplo, com derivados da hematoporfirina (PEPLOW , CHUNG e BAXTER, 2012). Além disso, corantes baseados em ftalocianinas podem ser seletivamente acumulados e eliminados do tecido alvo com maior eficiência.

Dentre o grupo das ftalocianinas, a cloro alumínio ftalocianina mereceu destaque, pois as suas propriedades fotoquímicas e fotofísicas já foram extensamente estudadas por diversos autores (NUNES , SGUILLA e TEDESCO, 2004; PRIMO et al., 2007; SIQUEIRA-MOURA et al., 2010; TEDESCO , ROTTA e LUNARDI, 2003) apresentando importantes parâmetros favoráveis ao seu uso como fármaco fotossensibilizante, tais como tempos de vida relativamente longos nos estados singlete e triplete, os quais são produzidos com rendimentos quânticos altos permitindo assim um complexo mecanismo de transferência de energia para a produção de EROs. A cloro alumínio ftalocianina (ClAlPc) é um macrociclo tetrapirrólico que possui átomos de nitrogênio ligando as unidades pirrólicas e o íon metálico central (Al), como mostra a Figura 2 (SIQUEIRA-MOURA et al., 2010). 


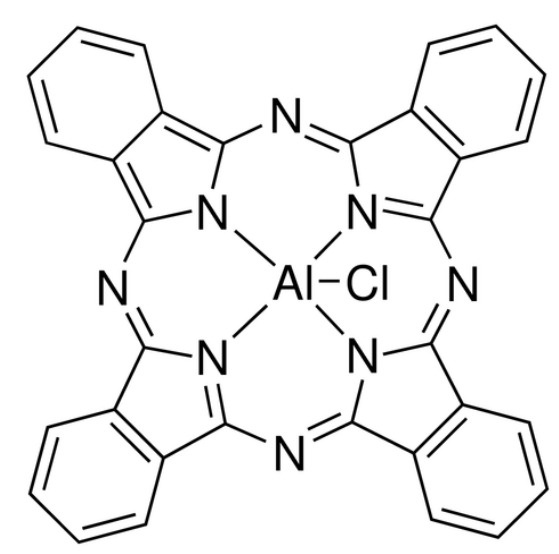

Figura 2. Estrutura molecular da Cloro Alumínio Ftalocianina Fonte: http://www.sigmaaldrich.com

O átomo halogênio substituído axialmente que se conecta ao metal central pode ser responsável por diferentes propriedades das ftalocianinas, bem como o íon metálico central. O átomo central de alumínio, por ser relativamente grande, fica deslocado da estrutura da molécula, o que faz com que esta deixa de ser plana, como é o caso da ftalocianina de zinco. Esta é uma informação importante na escolha do fármaco fotossensibilizante, visto que a estrutura não-planar da ClAlPc dificulta a formação de agregados em ambiente fisiológico.

Assim, as propriedades fotoquímicas e fotofísicas das ftalocianinas podem ser moduladas alterando os substituintes axiais e periféricos, metais centrais, assim como as estruturas nos anéis macrocíclicos (CHEN et al., 2009).

\subsection{O sistema de liberação de fármacos: nanoemulsão}

A presença de quatro grupos fenil na estrutura das ftalocianinas pode causar problemas de solubilidade e de agregação dessas moléculas (SIQUEIRA-MOURA et al., 2010). As ftalocianinas são frequentemente preparadas com grupos sulfônicos ácidos a fim de promover uma maior solubilidade em água quando átomos metálicos estão centralmente coordenados. (CASTANO , DEMIDOVA e HAMBLIN, 2004). A introdução de grupos substituintes é uma 
maneira de aumentar efetivamente a solubilidade das ftalocianinas, sendo que grupos diferentes podem causar efeitos diferentes nas propriedades ópticas e fotofísicas das ftalocianinas (CHEN et al., 2009).

Apesar dos esforços em melhorar as propriedades físicas das ftalocianinas, a relativamente baixa solubilidade em água faz com que seja necessária a utilização de um sistema de veiculação de fármacos anfifílico, ou seja, solúvel tanto em meio aquoso quanto em solventes orgânicos. O desenvolvimento de um sistema de liberação de fármacos é de suma importância para o uso da cloro alumínio ftalocianina em aplicações tópicas, como no caso do tratamento com TFD em feridas, visto que o veiculador não só proporciona um microambiente lipossolúvel ao fármaco, mas também mantém a sua concentração na faixa de ação terapêutica por um tempo prolongado, utilizando-se de uma única dosagem (PRIMO, F. L., 2009).

Vários tipos de sistemas de liberação de fármacos foram estudados e utilizados clinicamente, como as vesículas lipossomais (NUNES, S. M. T., 2000), micropartículas (GOMES, A. J., 2003), microemulsões (LENAERTS et al., 1995; SOPPIMATH et al., 2001), proteínas de baixa densidade (LENAERTS et al., 1995; NUNES, S. M. T., 2003; TEDESCO , ROTTA e LUNARDI, 2003), sistemas dendriméricos (HUGHES, 2005; PATRI , MAJOROS e BAKER, 2002), entre outros, com propriedades físico-químicas e biológicas favoráveis (SHIM et al., 2004; JENNING , SCHAFER-KORTING e GOHLA, 2000; SARIKAYA et al., 2003). Mais recentemente, os sistemas "nano" emergiram como uma opção mais interessante, provendo o máximo de eficácia terapêutica. A característica mais importante desses nanocarreadores é sua habilidade em aprimorar a interação e liberação do princípio ativo no seu sítio alvo (célula, órgão ou microrganismo). Além disso, esses carreadores coloidais podem apresentar as seguintes vantagens: prolongar a permanência do fármaco na corrente sanguínea (comum aumento da meia-vida plasmática), proteger o princípio ativo da 
degradação química ou enzimática após administração, diminuir os efeitos colaterais e aumentar a biodisponibilidade (BECHET et al., 2008; CHEN et al., 2011; HAMIDI , AZADI e RAFIEI, 2008; PASZKO et al., 2011). Assim, os novos sistemas propostos na literatura são as nanopartículas poliméricas biodegradáveis (nanoesferas e nanocápsulas), nanoemulsão, micelas poliméricas, lipossomas, dendrímeros, nanopartículas magnéticas e, mais recentemente, nanopartículas de géis (CHATTERJEE , FONG e ZHANG, 2008; CHEN et al., 2011; HAMIDI , AZADI e RAFIEI, 2008; KONAN , GURNY e ALLEMANN, 2002; SOUSSAN et al., 2009; KIRILOV et al., 2008).

Considerando que as nanoemulsões são formadas por gotículas de óleo dispersas em água, contendo tensoativo na interface óleo/água, estas possuem ótima capacidade de solubilização de substâncias lipofílicas, como é o caso da cloro alumínio ftalocianina, e têm sido utilizadas para aumentar a estabilidade, a solubilidade e a biodisponibilidade de fármacos, pois permitem a incorporação de vários tipos de compostos na fase interna oleosa, na região interfacial ou na fase externa aquosa (OLIVEIRA et al., 2003).

As nanoemulsões (NE) são sistemas coloidais, nos quais a fase interna constitui um microambiente dimensionalmente restrito, com propriedades particulares, podendo ligar ou associar moléculas com diferentes polaridades, atuando como agregados esféricos e com diâmetros menores que $1000 \AA$ (OLIVEIRA et al., 2003). As NE são, de forma geral, definidas como sistemas termodinamicamente estáveis, isotrópicos, de dois líquidos imiscíveis (usualmente água e óleo) estabilizados por um filme de compostos tensoativos, localizados na interface óleo/água (PRIMO, F. L., 2009).

Vários tipos de veículos de liberação de fármacos foram estudados por membros do grupo, como lipossomas, nanoemulsões, nanocápsulas, nanopartículas de organogel, nanopartículas magnéticas, nanotubos de carbono, entre outros (BARBUGLI, P. A., 2010; FERREIRA, D. M., 2012; PRIMO, F. L., 2009; SIMIONI et al., 2009; SIQUEIRA-MOURA, 
M. P., 2011; FALQUEIRO, A. M., 2011). Ao se verificar as propriedades físico-químicas e aplicações de cada um, a nanoemulsão pareceu ser a opção mais adequada como veiculador para a ClAlPc, devido às suas características lipofílicas já mencionadas.

Em seu trabalho de doutorado, Primo (PRIMO, F. L., 2009) desenvolveu e caracterizou esse sistema de veiculação de fármacos, o qual foi amplamente avaliado a partir de testes físico-químicos e ensaios de citotoxidade in vitro em cultura de fibroblastos humanos. Na sequência foram realizados estudos fotobiológicos combinando-se a aplicação de luz laser de baixa potência e o fármaco $(\mathrm{ClAlPc})$ em modelos teciduais, para avaliação da resposta biológica ao fotoestímulo. Os resultados demonstraram que a formulação ClAlPc/NE possui características fotofísicas no estado fundamental, de acordo com as exigências para utilização de fármacos e princípios ativos fotossensibilizantes em processos fotodinâmicos e laserterapia. O processo de incorporação do fármaco à nanoemulsão não suprimiu o potencial fluorescente do mesmo, o que também confirma a afinidade química e solubilidade adequada do ativo no ambiente nuclear lipofílico da nanopartícula coloidal. Além disso, o sistema nanoemulsão contendo o fármaco fotossensibilizante mostrou uma boa estabilidade termodinâmica, formulação relativamente simples de preparar e reprodutibilidade (PRIMO, F. L., 2009).

\subsection{A pele e a penetração da luz no tecido}

A pele é o maior órgão do corpo humano, atingindo 16\% do seu peso corporal. Assim como outros órgãos, ela tem a habilidade de crescer, se desenvolver e de ser reparada (regeneração). A pele recobre a superfície do corpo e apresenta-se constituída por uma porção epitelial de origem ectodérmica, a epiderme, e uma porção conjuntiva de origem mesodérmica, a derme. Dependendo da espessura da epiderme, variando de 50 a $150 \mu \mathrm{m}$, 
distingue-se a pele fina e a espessa. A pele espessa é encontrada na palma das mãos e na planta dos pés. O resto do corpo é protegido por pele fina (JUNQUEIRA e CARNEIRO, 2004).

A espessura da derme varia de $300 \mu \mathrm{m}$ nas pálpebras até $3 \mathrm{~mm}$ nas costas. O principal componente da derme é a matriz extracelular (MEC). Essa matriz consiste de proteínas suportes complexas, tais como colágeno, elastina e proteoglicanas, as quais são sintetizadas pelos fibroblastos dermais. A derme pode ser dividida em derme papilar, situada diretamente abaixo da epiderme, e derme reticular, localizada entre a derme papilar e a hipoderme. A hipoderme, também chamada de camada subcutânea, é um tecido conjuntivo frouxo composto primariamente de células de gordura (DAMS et al., 2011).

A pele desempenha múltiplas funções. Graças à camada córnea da epiderme protege o organismo contra a perda de água e contra o atrito. A junção entre a epiderme e a derme é irregular. A derme possui projeções, as papilas dérmicas, que se encaixam em reentrâncias da epiderme, aumentando a coesão entre essas duas camadas. Os pêlos, unhas e glândulas sudoríparas e sebáceas são estruturas anexas da pele (JUNQUEIRA e CARNEIRO, 2004). A Figura 3 é uma ilustração das camadas constituintes da pele mostrando também as suas estruturas. 


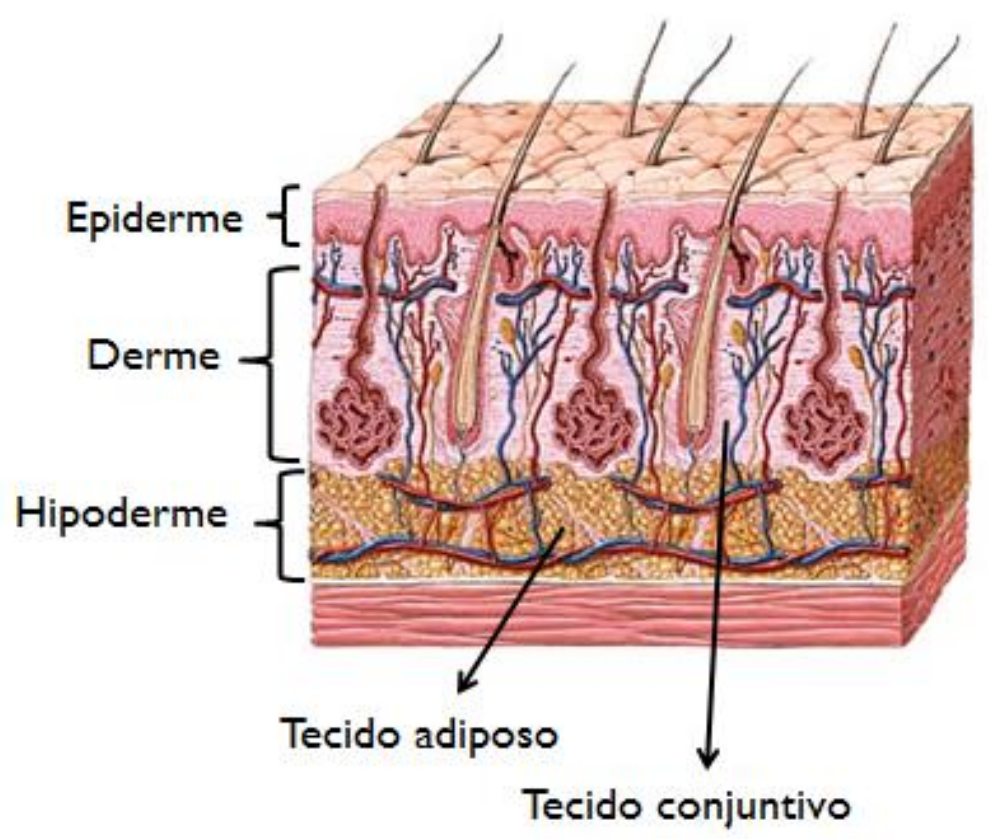

Figura 3. Esquema das camadas da pele e estruturas anexas. Adaptado de: http://www.nlm.nih.gov/medlineplus/ency/imagepages/8912.htm

Na TFD é importante estar apto para prever a distribuição espacial da luz no tecido alvo. A luz pode ser espalhada ou absorvida quando entra no tecido, e a extensão de ambos os processos depende do tipo de tecido e do comprimento de onda da luz. Absorção é principalmente devida a cromóforos endógenos, como hemoglobina, mioglobina e citocromos. Espalhamento é geralmente o fator mais importante na determinação da penetração da luz na maioria dos tecidos. A combinação da absorção de luz de menores comprimentos de onda por importantes cromóforos do tecido (como oxi e desoxihemoglobina e melanina) juntamente com espalhamento de luz reduzido em comprimentos de onda mais longos e a ocorrência da absorção pela água em comprimentos de onda maiores do que $1300 \mathrm{~nm}$ levou ao conceito de "janela óptica" do tecido (Figura 4). Em termos de TFD, a média efetiva de penetração pela luz no tecido é de aproximadamente $1-3 \mathrm{~mm}$ em $630 \mathrm{~nm}$ (CASTANO, DEMIDOVA e HAMBLIN, 2004). 


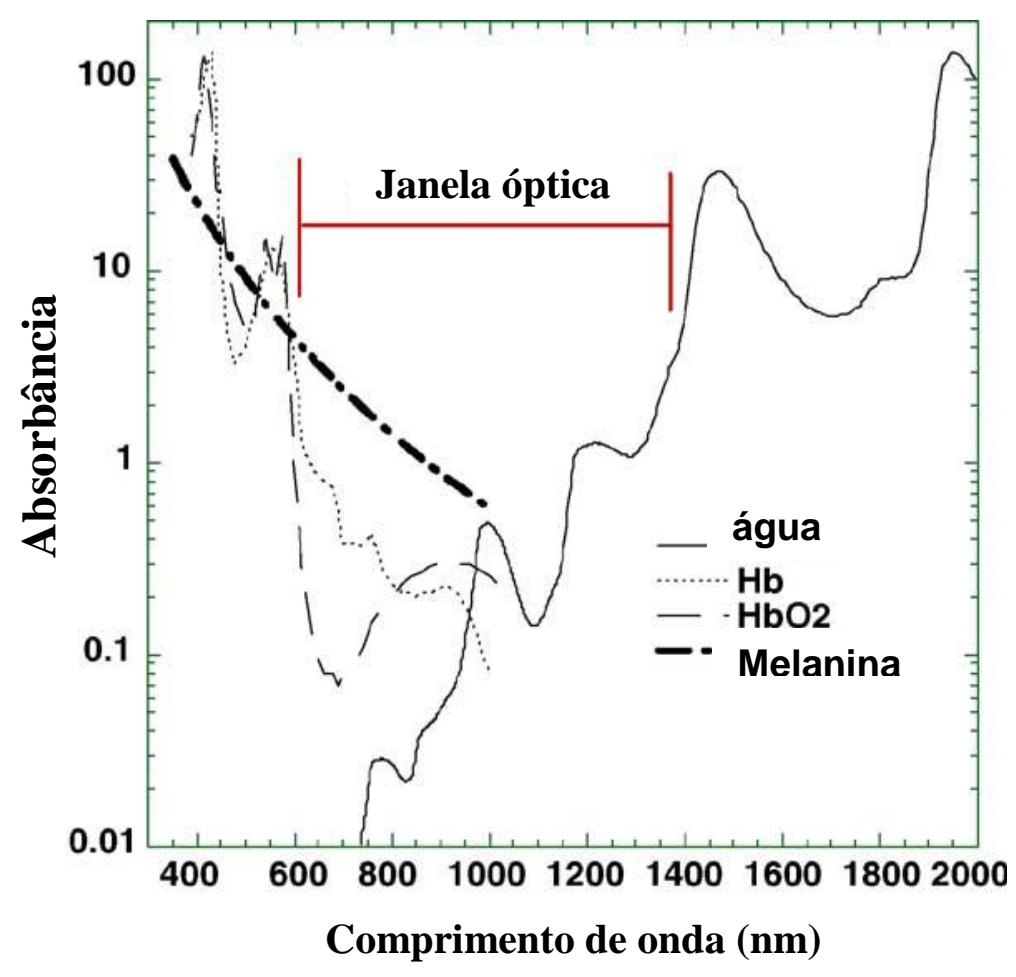

Figura 4. Janela óptica no tecido. Espectro de absorção de importantes cromóforos do tecido, como água, oxi e desoxihemoglobina e melanina, plotados em escala logarítmica (adaptado de CASTANO, DEMIDOVA e HAMBLIN, 2004).

A Figura 5 é uma ilustração das camadas da pele e o que ocorre com a luz em cada uma delas.

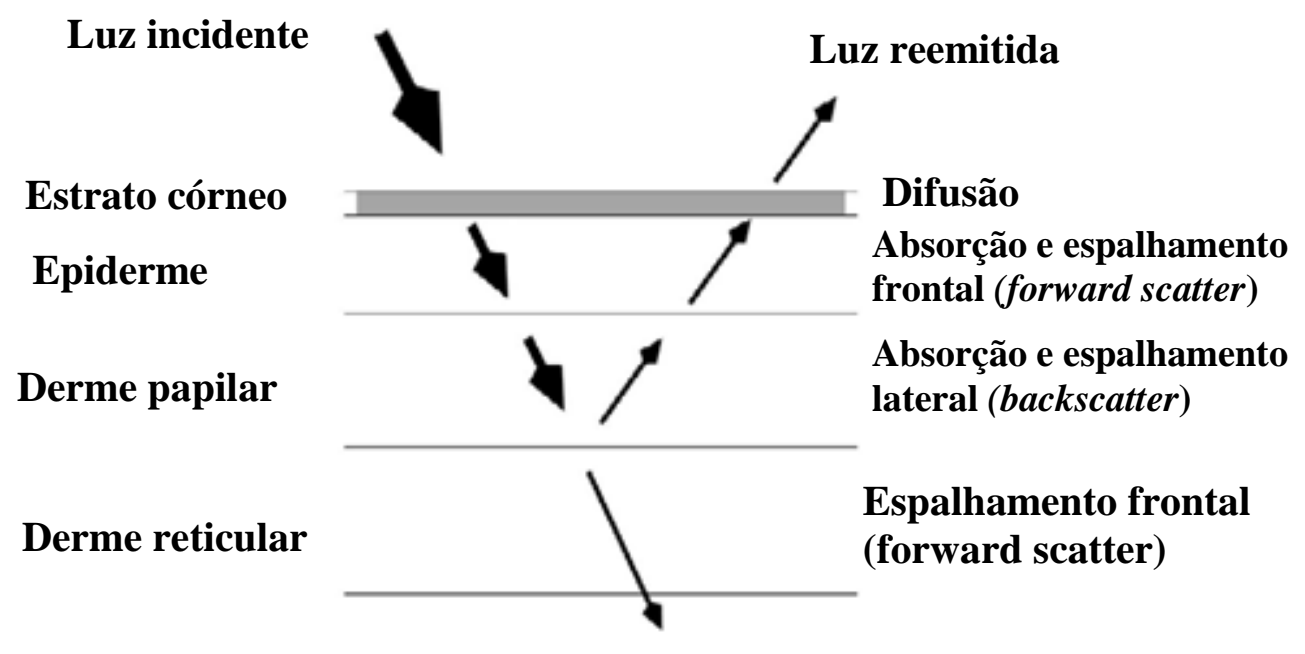

Figura 5. Representação esquemática das camadas da pele e as suas propriedades ópticas. As setas indicam o caminho da luz pelos tecidos da pele (adaptado de CLARIDGE et al., 2003). 
O estrato córneo é uma camada protetora que consiste de células impregnadas por queratina e varia consideravelmente com a espessura. Exceto pela luz espalhada, ele é oticamente neutro. Já na camada epidérmica existe um pequeno espalhamento de luz, com uma pequena quantidade de luz que passa direto. O resultado é que se considera que toda luz não absorvida pela melanina, principal pigmento, presente na epiderme pode passar para a derme (CLARIDGE et al., 2003).

A derme é formada por fibras colágenas e, diferentemente da epiderme, ela contém sensores, receptores, vasos sanguíneos e terminações nervosas. A hemoglobina, presente nos vasos sanguíneos em toda a derme, atua como um absorvedor seletivo de luz. A derme consiste de duas camadas estruturalmente diferentes, papilar e reticular, as quais diferem principalmente no tamanho das fibras de colágeno. O pequeno tamanho das fibras colágenas na derme papilar (diâmetro na ordem de magnitude menor do que a luz visível incidente) faz com que ocorra nesta camada o "back-scattering", no qual a luz é totalmente direcionada de volta à superfície da pele (CLARIDGE et al., 2003).

A luz azul penetra menos eficientemente pelo tecido, enquanto radiação vermelha e infravermelha penetram mais profundamente, como mostra a Figura 6. Assim como a Figura 5, a Figura 6 também apresenta o caminho percorrido pela luz no tecido, porém evidenciando os diferentes tipos de luz. Nenhuma fonte de luz é ideal para todas as indicações de TFD, mesmo para o mesmo agente fotossensibilizante. A escolha da fonte de luz deve ser baseada na absorção do fármaco fotossensibilizante, tipo de doença a ser tratada (localização, tamanho da lesão, acessibilidade e características do tecido), custo e tamanho (AGOSTINIS et al., 2011). 


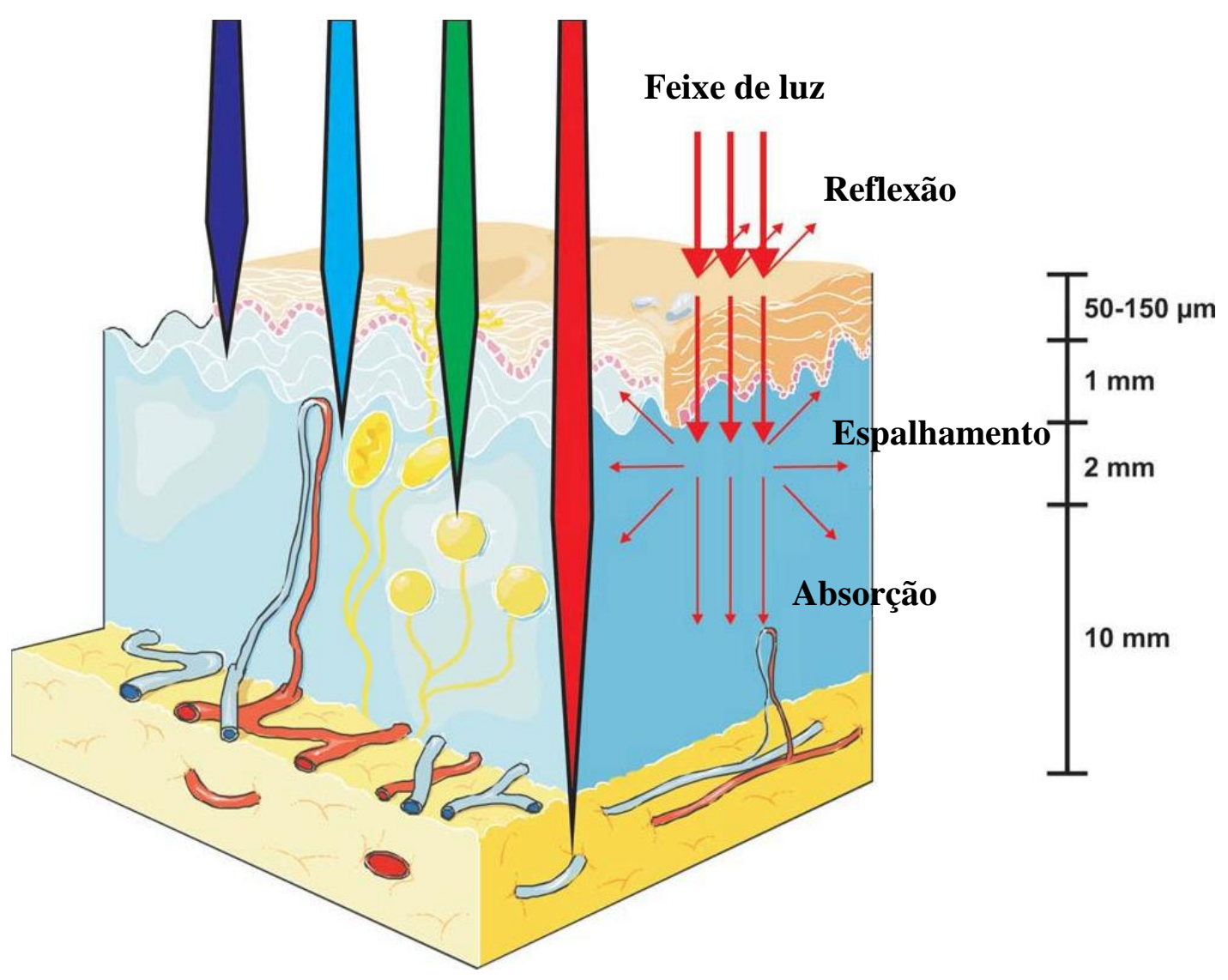

Figura 6. Propagação da luz pelos tecidos (adaptado de AGOSTINIS et al., 2011)

\subsection{Colágeno e Elastina}

O colágeno constitui um tipo de família de proteínas selecionadas durante a evolução para exercer diferentes funções (principalmente estruturais). Durante o processo de evolução dos organismos, a família de um grupo de proteínas estruturais influenciada pelo meio ambiente e pelas necessidades funcionais do organismo dos animais modificou-se e adquiriu variáveis graus de rigidez, elasticidade, e força de tensão. Estas proteínas são conhecidas coletivamente como colágeno, e os principais exemplos dos vários tipos de colágeno são encontrados na pele, osso, cartilagem, músculo liso e lâmina basal (JUNQUEIRA e CARNEIRO, 2004). 
A síntese de colágeno foi inicialmente associada a um grupo restrito de células do conjuntivo, como os fibroblastos, condroblastos e osteoblastos. Atualmente, entretanto, existem suficientes evidências que mostram que vários tipos de células produzem esta proteína. As fibrilas de colágeno são formadas pela polimerização de unidades moleculares alongadas denominadas tropocolágeno, sendo que os vários tipos de colágeno resultam de diferenças na estrutura química destas cadeias polipeptídicas. Nos colágenos tipo I, II e III as moléculas de tropocolágeno se agregam em subunidades que se juntam para formar fibrilas. Nos colágenos do tipo I e III estas fibrilas se associam para formar fibras. O colágeno tipo II, presente na cartilagem, forma fibrilas, mas não forma fibras. O colágeno tipo IV, presente nas lâminas basais, não forma fibrilas nem fibras (JUNQUEIRA e CARNEIRO, 2004; SHOULDERS e RAINES, 2009).

O colágeno é o tipo mais abundante de proteína do organismo, representando $30 \%$ do seu peso seco. Os tipos de colágeno dos vertebrados constituem uma família de proteínas produzidas por diferentes tipos de células e se distinguem por sua composição química, características morfológicas, distribuição, funções e patologias. Como o colágeno é a principal proteína estrutural e compõe de 70 a $80 \%$ do peso seco da pele, a modulação do metabolismo do colágeno na pele por irradiação terapêutica possui muita importância clínica. O colágeno da pele sintetizado por fibroblastos compromete de 80 a $85 \%$ de colágeno tipo I e de 10 a 15\% de colágeno tipo III (RIEKKI et al., 2000).

A mudança na constituição da matriz extracelular é um importante fator do envelhecimento. Fibras de colágeno associadas com proteoglicanas são importantes componentes da derme, e a pele saudável é dependente do balanço entre a síntese e degradação de colágeno. A formação e degradação do colágeno são primariamente controladas pela atividade de metaloproteases da matriz (MMPs), e a inativação das MMPs 
reduz a formação de rugas (VALENTI et al., 2012; BISSONNETTE, 2011; SZEIMIES et al., 2012).

A elastina é a principal proteína da matriz extracelular que fornece força e elasticidade a vários tecidos flexíveis e mecanicamente ativos, incluindo pele, pulmões e cordas vocais. (GRIESHABER et al., 2012). As principais células produtoras de elastina são os fibroblastos e o músculo liso dos vasos sanguíneos. Antes da elastina madura forma-se a proelastina, uma molécula globular de $70 \mathrm{kDa}$ de massa, que, no espaço extracelular, polimeriza-se para formar a elastina, uma glicoproteína com consistência de borracha que predomina nas fibras elásticas maduras. A elastina é resistente à fervura, à extração com álcalis e com ácido e à digestão com proteases usuais, mas é facilmente hidrolisada pela elastase pancreática (JUNQUEIRA e CARNEIRO, 2004).

Como a proteína colágeno, a elastina é rica em glicina e em prolina. Além destes, a elastina contém dois aminoácidos incomuns, a desmosina e a isodesmosina, formados por ligações covalentes entre quatro resíduos de lisina. Estas ligações cruzadas parecem ser responsáveis pela consistência elástica da elastina, que é cinco vezes mais extensível do que a borracha (JUNQUEIRA e CARNEIRO, 2004).

\subsection{O processo cicatricial}

No Egito antigo, de uma perspectiva parafisiológica, uma ferida era considerada como uma abertura no corpo pela qual seres infernais poderiam entrar ou sair (SIPOS et al., 2004). Desde aquele tempo a medicina já estava sendo desenvolvida, e o tratamento de feridas consistia da aplicação de bandagens contendo medicamento, no caso ervas com poder de cura, sobre a lesão. Até não muito tempo atrás, cerca de 50 anos, este era método utilizado, considerando os avanços dos medicamentos e das técnicas medicinais. 
A regeneração da epiderme em mamíferos foi descrita convencionalmente por histologistas por consistir de três fases: mitose, migração e diferenciação (ODLAND e ROSS, 1968). A cicatrização de feridas é um processo complexo, cujo desenvolvimento pode ser resumido em três etapas: inicialmente um estágio inflamatório, seguido de proliferação e finalizando com o reparo em um estágio de remodelação do tecido (AUKHIL, 2000).

A fase inflamatória depende, além de inúmeros mediadores químicos, das células inflamatórias, como os leucócitos polimorfonucleares (PMN), macrófagos e linfócitos. Os PMN atuam no momento da injúria tecidual e ficam por um período que varia de três a cinco dias e são eles os responsáveis pela fagocitose das bactérias. O macrófago é a célula mais importante desta fase e este permanece na ferida do terceiro ao décimo dia. O macrófago fagocita bactérias, desbrida corpos estranhos e direciona o desenvolvimento do tecido de granulação. Os linfócitos aparecem na ferida em aproximadamente sete dias e seu papel ainda não é bem definido, porém sabe-se que as linfocinas produzidas por estas células têm importante influência sobre os macrófagos. Além das células e dos mediadores químicos, a fase inflamatória conta com o importante papel da fibronectina, a qual é sintetizada por uma variedade de células como os fibroblastos e as células endoteliais, funcionando como adesivo para consolidar o coágulo de fibrina, as células e os componentes da matriz extracelular (MOULIN et al., 2000).

A fase de proliferação celular é importante na formação do tecido de granulação (coleção de elementos celulares, incluindo fibroblastos, células inflamatórias, endoteliais e componentes da matriz extracelular, como a fibronectina, as glicosaminoglicanas e o colágeno). A formação do tecido de granulação depende da ação dos fibroblastos que além de produzirem o colágeno, produzem também elastina, fibronectina, glicosaminoglicanas e proteases, estas responsáveis pelo desbridamento e remodelamento fisiológico. Durante a fase 
de proliferação também ocorre a angiogênese, essencial para o suprimento de oxigênio e nutrientes para a cicatrização (BALBINO, PEREIRA e CURI, 2005).

As duas últimas fases, de contração e de remodelação, são processos mais tardios, responsáveis pela maturação das feridas. A primeira se dá com participação intensa dos miofibroblastos e tem como consequência a redução do tamanho da lesão. A segunda, decorrente da formação de pontes entre as fibras de colágeno, tem como resultado a formação de cicatriz madura (CHAUSSAIN-MILLER et al., 2002; MOULIN et al., 2000).

Os fibroblastos exercem papel importante numa série de eventos fisiológicos, como é o caso do processo cicatricial. Neste caso, os fibroblastos do tecido conjuntivo das margens tornam-se ativados, proliferam, migram em direção ao coágulo em reabsorção e começam a sintetizar os componentes da matriz extracelular, como colágeno e elastina (BALBINO , PEREIRA e CURI, 2005; PAZOS e NADER, 2007; ROCHA, 2004). Durante o processo cicatricial, a quantidade de colágeno aumenta com o tempo e por volta de duas semanas suas fibras passam a predominar na matriz extracelular. As células fagocitárias vão desaparecendo e o tecido de granulação passa a ser constituído por um tecido conjuntivo progressivamente mais denso e menos vascularizado, situado logo abaixo da epiderme já regenerada (ROCHA, 2004). A degradação do colágeno se inicia precocemente e é muito ativa durante o processo inflamatório, portanto, a formação da matriz extracelular é resultante de um balanço entre a deposição e degradação de colágeno (SIMIONI, A. R., 2009).

O processo de cicatrização envolve vários eventos celulares e macromoleculares que acontecem nas diferentes fases da cicatrização. Esta sucessão implica em um elaborado programa de síntese que permite variações qualitativas e quantitativas das matrizes extracelulares necessárias não somente ao processo sequencial de cicatrização, mas também a uma remodelagem intensa, na qual estão envolvidas várias famílias de proteases, dentre as quais se destacam as metaloproteases (MMPs) (PRIMO, F. L., 2009). 
As metaloproteases de matriz são denominadas como endopeptidases dependentes de cálcio, que contêm zinco e são estrutural e funcionalmente relacionadas umas às outras (BODE e MASKOS, 2003). A principal função das MMPs é atuar na degradação e formação da matriz extracelular. Dessa forma, as MMPs podem influenciar diversas propriedades celulares como crescimento, morte e migração (COUSSENS , FINGLETON e MATRISIAN, 2002). No processo cicatricial, as MMPs interferem diretamente em eventos celulares e moleculares. Na fase inflamatória, as MMP-2 e MMP-9 atuam como mediadores químicos nas etapas de estimulação na fase fagocitária. Na granulação (proliferação) as MMPs atuam em conjunto com outras biomoléculas com atividade reguladora na formação da matriz extracelular de colágeno e elastina, re-epitelização e vascularização (NELSON e MELENDEZ, 2004; SHARWANI et al., 2006; STERNLICHT e WERB, 2001; MCCAWLEY e MATRISIAN, 2001).

Diversas rotas de sinalização envolvidas no controle da transcrição das MMPs são controladas por reações do tipo redox. Este raciocínio levou pesquisadores a proporem uma relação entre a atividade das MMPs e espécies reativas de oxigênio. Sugere-se que as EROs atuam na ativação ou desativação de algumas MMPs em nível transcricional, atuando em rotas de sinalização redox-sensíveis (NELSON e MELENDEZ, 2004).

Dessa forma, para compreender os mecanismos de ação de um fármaco fotossensibilizante seguido da irradiação por luz diretamente sobre a pele (em biópsias de explants de pele) é preciso estudar a expressão e a ativação das MMPs no meio de cultura, podendo assim fazer uma correlação com os níveis de EROs produzidos e expandir essa compreensão para o processo cicatricial. 


\subsection{Zimografia}

Os métodos eletroforéticos são a principal ferramenta no estudo de proteínas, como é o caso das enzimas MMPs. A separação de misturas proteicas por eletroforese começou no início do século vinte. O primeiro método, utilizando um complexo aparato com solução Tiselius, foi substituído por géis de corrida, e até hoje géis de poliacrilamida têm se tornado uma importante ferramenta em laboratórios que trabalham com proteínas e ácidos nucleicos (PAGANO, 1999).

Um estudo (DAMODHARAN , GANESAN e RADHAKRISHNAN, 2011) utilizou dois métodos baseados em eletroforese no estudo da expressão das enzimas MMP-2 e MMP9. No primeiro, a expressão gênica das MMPs foi detectada pela técnica de PCRTranscriptase reversa, e os produtos analisados por eletroforese em gel de agarose e as bandas de DNA visualizadas. O outro método foi a técnica de zimografia eletroforética em gel de gelatina e poliacrilamida, a qual detecta a atividade das enzimas MMP-2 e MMP-9 (Gelatinases A e B, respectivamente), uma vez que elas degradam o gel. Ambos os métodos são eficientes, porém o segundo permite detectar diretamente a atividade das enzimas, sem a necessidade de outro método, por isso é empregado especificamente para esse caso.

Dessa forma, a técnica de zimografia se baseia na capacidade das enzimas MMP-2 e MMP-9 em degradarem a gelatina, podendo não somente detectar a presença dessas enzimas nos meio de cultura, mas também quantificar as suas atividades de acordo com a intensidade das bandas no gel. Essa é a principal diferença entre a técnica de zimografia e os outros métodos eletroforéticos convencionais, como o método clássico em gel de agarose. 


\section{Objetivos}

\section{$2.1 \quad$ Objetivo geral}

Verificar os efeitos da fototerapia, utilizando o fármaco fotossensibilizante cloro alumínio ftalocianina, com o intuito de estimular a produção de colágeno e elastina, os quais exercem papel importante no processo regenerativo da pele.

\subsection{Objetivos específicos}

a) Preparar e caracterizar a formulação ClAlPc nanoestruturada, através da determinação de parâmetros farmacotécnicos como estabilidade, através de medidas de potencial Zeta, tamanho médio das gotículas e homogeneidade da nanoemulsão, além das características espectroscópicas, tais como absorção na região do UV-Vis e rendimentos de fluorescência;

b) Avaliar a ação de diferentes doses de luz combinadas com o fármaco fotossensibilizante em biópsias de explants de pele no processo de regeneração e expressão proteica;

c) Analisar histomorfologicamente as biópsias coradas por Orceína e Picrosirus Red e quantificar os seus componentes como elastina, colágeno tipo I e colágeno tipo III;

d) Avaliar a ação de enzimas como as metaloproteases (MMP-2 e MMP-9), importantes no processo cicatricial, utilizando a técnica de zimografia eletroforética a partir dos meios coletados após experimento com as biópsias de explants de pele. 


\section{Materiais e Métodos}

\subsection{Materiais}

Todas as soluções aquosas, incluindo tampões, meio de cultura, entre outras, foram preparadas com água ultrapura, obtida através do sistema de filtração Direct-Q, com filtro de 0,22 $\mu \mathrm{m}$, da Millipore (Molsheim, França).

O fármaco fotossensibilizante utilizado foi a cloro alumínio ftalocianina (fórmula empírica $\mathrm{C}_{32} \mathrm{H}_{18} \mathrm{AlClN}_{8}$ ) procedente da Sigma-Aldrich Chem. Co. (Milwaukee, EUA), com pureza de $85 \%$. Todos os experimentos foram realizados a partir de um único lote do fármaco (14154-42-8).

Para o cultivo da linhagem celular HT-1080, preparação dos equivalentes dermais, bem como das biópsias de explants de pele foi utilizado o meio Dubleco Eagle's Minimum Essential Medium - DMEM (Gibco BRL, EUA) contendo $100 \mathrm{U} / \mathrm{mL}$ de penicilina, 100 $\mu \mathrm{g} / \mathrm{mL}$ de estreptomicina (Gibco BRL, EUA), 2,5 $\mu \mathrm{g} / \mathrm{mL}$ de anfotericina B (Gibco BRL, EUA), $200 \mu \mathrm{M}$ de glutamina (Gibco BRL, EUA), constituído de uma mistura de sais enriquecidos com aminoácidos, vitaminas e outros componentes essenciais para o crescimento celular.

Nos estudos histopatológicos para fixação e coloração das biópsias foram utilizados os seguintes materiais: formaldeído $37 \%$ estabilizado com 10-15\% de metanol (ACROS, Bélgica) para fixação das biópsias, Orceína (Sigma-Aldrich, EUA) para coloração da rede de elastina e Picrosirus Red (Sigma-Aldrich, EUA) para a coloração da rede de colágeno.

O colágeno utilizado na preparação dos géis para incorporação das biópsias de pele foi obtido conforme protocolo que será descrito posteriormente na sessão 3.3.3. 
Nos experimentos de zimografia eletroforética utilizaram-se os seguintes reagentes para preparo dos géis e das soluções tampões: bis/acrilamida 40\% (Bio-Rad, EUA), SDS 20\% (BioRad, EUA), azul de coomassie G250 (Bio-Rad, EUA), Tris (Bio-Rad, EUA), glicina (Bio-Rad, EUA), persulfato de amônio - APS (Bio-Rad, EUA), N,N,N,N-tetrametil etileno diamina TEMED 5\% (Bio-Rad, EUA), azul de bromofenol (Merck, Alemanha), Triton X-100 (SigmaAldrich, EUA) e gelatina tipo A (Sigma-Aldrich, EUA).

\subsection{Equipamentos}

Nos estudos espectrofotométricos foi utilizado o espectrofotômetro de absorção Lambda 20 da Perkin Elmer (Waltham, EUA), e nos estudos de emissão de fluorescência foi utilizado o espectrofluorímetro Fluorolog-3 da Jobin Yvon-SPEX (Longjumeau, França).

Nos estudos de tamanho de partícula, índice de polidispersão e potencial zeta foi utilizado o equipamento Zetasizer (Nano-ZS da Malvern- R.U.), o qual permite realizar medidas não invasivas por "backscatter optics" (NIBS) e determinar partículas no intervalo de $2 \mathrm{~nm}$ a $3 \mu \mathrm{m}$.

O sistema laser utilizado nos ensaios de bioestimulação luminosa foi um diodo-laser Eagle (Quantum Tech, São Carlos-SP, Brasil) com feixe de excitação em 670 nm, trabalhando numa potência máxima $0,67 \mathrm{~W}$ acoplado a um feixe óptico de $1 \mathrm{~cm}$ de comprimento.

As imagens obtidas após análise histológica foram registradas utilizando-se um microscópio óptico modelo Axiovert 40-CFL da Carl Zeiss (Oberkochen, Alemanha), acoplado a uma câmera digital Axio-Cam MRC de alta resolução, com conjunto de objetivas para aumento de 10, 20, 40 e $100 \mathrm{X}$, calibradas para escalas micrométricas (contraste de fase, 
plasdic e emissão de fluorescência). O software AxioVision Release 4.8.2.da Carl Zeiss (Oberkochen, Alemanha) permitiu a quantificação das estruturas presentes nessas imagens.

Nos estudos de expressão das metaloproteases foi utilizado o aparato para zimografia eletroforética vertical, modelo Protean ${ }^{\circledR}$ III da Bio-Rad (Hercules, EUA) com cuba para dois géis alimentada por uma fonte Bio-Rad modelo PowerPac Basic ${ }^{\circledR}$ operando com voltagem máxima de $300 \mathrm{~V}$, corrente de $400 \mathrm{~mA}$ para uma potência máxima de $75 \mathrm{~W}$. As placas espaçadoras utilizadas foram de 1,0 mm para 10 poços.

Para a obtenção e digitalização das imagens dos géis de zimografia foi utilizado o sistema de aquisição de imagens da UVITec Cambridge (R.U.), modelo UVIdoc HD2/20M, com câmera de 1.4 megapixels e câmara ultravioleta. Já a quantificação das imagens foi realizada por meio do software GeneTools da Syngene (Cambridge, R.U.) utilizado no laboratório do Prof. Dr. Adalberto Luiz Rosa do Departamento de Cirurgia, Traumatologia Buco-Maxilo-Facial e Periodontia da Faculdade de Odontologia de Ribeirão Preto - USP.

Utilizaram-se também os seguintes equipamentos de rotina: balança analítica eletrônica da Denver Instruments Company (Bohemia, EUA) modelo A-200 DS, agitador de tubos Phoenix AP-56 (Araraquara - SP, Brasil), ultrassom Branson modelo 2210 da Bransonic ${ }^{\circledR}$ Ultrasonic cleaner (Danbury, EUA), pH-metro de bancada Qualxtron, modelo QX 1500 Plus da Hexis Científica (Indaiatuba-SP, Brasil). 


\subsection{Métodos}

\subsubsection{Preparo do sistema de liberação de fármacos: nanoemulsão}

A nanoemulsão do tipo óleo em água foi preparada empregando-se a técnica de emulsificação espontânea, como descrito por PRIMO,F.L., 2009. Primeiramente preparou-se uma solução aquosa contendo o polímero da classe dos poloxamers. Consecutivamente, foi preparada uma solução orgânica (em acetona) contendo a fosfatidilcolina de soja, sob agitação magnética e aquecimento a $55^{\circ} \mathrm{C}$. A esta fase adicionou-se um volume de óleo Miglyol numa concentração final de 1 a 2,5\%. Após homogeneização, a fase orgânica foi então adicionada lentamente, com auxílio de uma seringa, diretamente à solução aquosa contendo o polímero. A última etapa de preparo consistiu na extração total do solvente orgânico pós-emulsificação, utilizando-se um rotaevaporador com banho a $85^{\circ} \mathrm{C}$ e pressão reduzida para se obter um volume final de $10 \mathrm{~mL}$.

A cloro alumínio ftalocianina (ClAlPc) foi incorporada ao sistema coloidal nanoestruturado diretamente na fase oleosa, sob agitação vigorosa, numa concentração final de $0,05 \mathrm{mg} \mathrm{mL}^{-1}$. Esta fase orgânica foi então adicionada durante o processo de preparo de nanoemulsões, como descrito anteriormente.

\subsubsection{Caracterização físico-química da nanoemulsão contendo ClAlPc}

\subsubsection{Determinação do tamanho das gotículas, índice de polidispersão e potencial Zeta}

Na determinação do tamanho das gotículas, índice de polidispersão e potencial Zeta da nanoemulsão contendo ClAlPc utilizou-se o equipamento Zetasizer modelo Nano ZS90 da Malvern (R.U.), conforme descrito no item 3.2. 
O diâmetro médio das gotículas que formam a nanoemulsão e a distribuição de tamanho (índice de polidispersão - IPd) foram determinados pela análise por espalhamento dinâmico de luz (espectroscopia de correlação de fótons, PCS). As análises foram realizadas em ângulo de varredura de $173^{\circ}$ e após diluição de $30 \mu \mathrm{L}$ da formulação em $3 \mathrm{~mL}$ de água ultrapura. Já o potencial Zeta foi determinado pela mobilidade eletroforética das amostras coloidais. Todas as determinações foram feitas em triplicata a $25^{\circ} \mathrm{C}$ com diluição idêntica à descrita anteriormente. As leituras foram realizadas utilizando-se os conjuntos de cubetas de acrílico padronizadas do próprio equipamento.

\subsubsection{Estudos de estabilidade}

A formulação contendo ClAlPc foi estocada a $4^{\circ} \mathrm{C}$ em frasco de vidro, selado e protegido da luz durante um período de 3 meses. Foram realizadas medidas de diâmetro médio das gotículas, índice de polidispersão e potencial Zeta (item 3.3.2.1) a cada 7 dias durante este período de estocagem, podendo-se avaliar assim a estabilidade da formulação no período de 3 meses. O monitoramento do comportamento termodinâmico é essencial para se validar o método de preparação, além de delinear as condições de caracterização para estudos posteriores.

\subsubsection{Doseamento da ClAlPc na nanoemulsão}

A determinação do conteúdo de ClAlPc na nanoemulsão foi realizada por espectrofotometria de absorção na região do UV-Vis. Os espectros foram determinados no estado estacionário e obtidos utilizando-se cubetas de quartzo com 1,0 cm de caminho óptico. Foi preparada uma solução diluindo $100 \mu \mathrm{L}$ da nanoemulsão contendo o fármaco (solução 
estoque) em $3 \mathrm{~mL}$ de acetonitrila, seguindo o método já validado descrito por SIQUEIRAMOURA et al., 2010.

\subsubsection{Extração de colágeno tipo I}

O colágeno utilizado na preparação dos géis foi proveniente de um material anteriormente obtido, conforme citado em PRIMO, F.L., 2009. O protocolo experimental foi revisado e aprovado pelo Comitê de Pesquisas em Humanos (protocolo 2007.1.487.58.7, Ribeirão Preto, Universidade de São Paulo, Brasil). O colágeno tipo I foi extraído a partir de tendões de caudas de ratos Wistar machos com 10 semanas e com peso aproximado de $300 \mathrm{~g}$. Foram obtidas 10 caudas, as quais foram lavadas e colocadas em banho de álcool. Posteriormente, as caudas foram dessecadas removendo-se a ponta de cada fio de tendão exposto, que foi retirado com auxílio de uma pinça e imediatamente colocado sobre uma placa de Petri contendo água destilada. Todos os tendões removidos foram recolhidos, pesados e colocados em uma solução de ácido acético glacial 5\%. A solução obtida permaneceu em geladeira a $4^{\circ} \mathrm{C}$ por uma semana, sendo agitada diariamente para garantir uma boa extração. Transferiu-se esta solução para garrafas de $250 \mathrm{~mL}$ estéreis, as quais foram centrifugadas por $2 \mathrm{~h}$ a $6.000 \mathrm{rpm}$ em rotor Sorvall SLA 1500 , a $4{ }^{\circ} \mathrm{C}$, para remoção de partículas suspensas. Após esse processo, foram obtidos aproximadamente $1 \mathrm{~L}$ de colágeno, o qual foi armazenado em geladeira a $4^{\circ} \mathrm{C}$ para uso posterior.

\subsubsection{Preparação das biópsias de explants de pele e dos géis de colágeno}

Neste trabalho de pesquisa, utilizou-se como matriz suporte para o cultivo das biópsias explants de pele uma matriz formada por gel de colágeno. A escolha deste tipo de matriz se 
deve ao fato de que o colágeno, além de ser um biopolímero, apresenta a vantagem de estimular a migração e proliferação celular, auxiliando no processo regenerativo. Para o cultivo celular em gel de colágeno, as biópsias de pele humana (explants de pele obtidos durante cirurgia plástica de coxa de doadores saudáveis) foram primeiramente limpas pela remoção da camada de gordura. A pele limpa foi lavada com meio de cultura DMEM na presença de antibióticos e anfotericina B e na ausência de soro fetal bovino. Após a lavagem, as peles foram cortadas em círculos com $4 \mathrm{~mm}$ de diâmetro, utilizando-se um instrumento apropriado chamado punch, e mantidas em placas contendo meio DMEM 20\%, conforme previamente estabelecido por (NAVEAU et al., 2007). A Figura 7 ilustra como é feito o corte das biópsias de pele, porém na situação real a camada de gordura (camada inferior) foi removida.

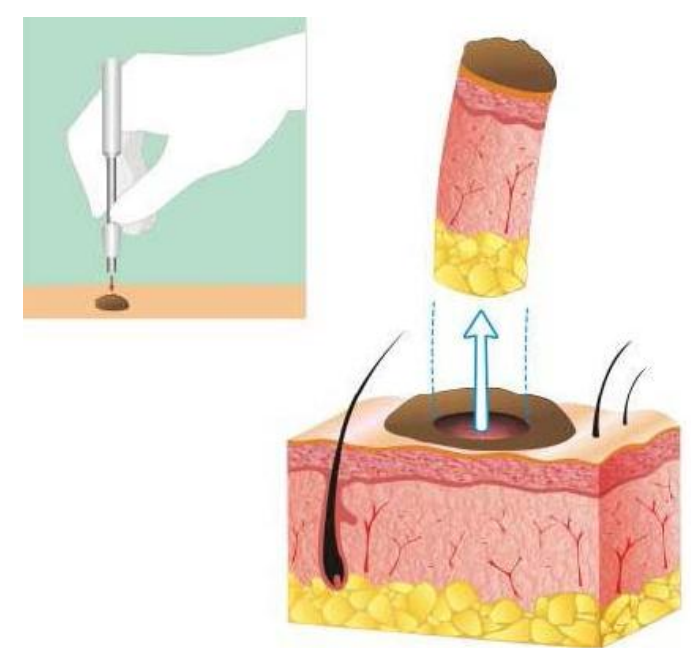

Figura 7. Corte da pele com o instrumento punch evidenciando as suas três camadas: epiderme, derme e hipoderme. Fonte: http://piel-l.org/libreria/item/917

Os géis de colágeno contendo as biópsias de pele foram preparados em placas de Petri de $60 \mathrm{~mm}$, de acordo com a seguinte composição: meio DMEM suplementado com 10\% de soro de fetal bovino, $100 \mathrm{U} / \mathrm{mL}$ de penicilina, $100 \mu \mathrm{g} / \mathrm{mL}$ de estreptomicina e $2,5 \mu \mathrm{g} / \mathrm{mL}$ de anfotericina $\mathrm{B}$, solução de colágeno tipo I e $\mathrm{NaOH} 0,1 \mathrm{M}$ para ajuste de $\mathrm{pH}$ para 7,4. Todo o procedimento foi realizado com um controle rigoroso de temperatura evitando que o processo 
de colagenização se iniciasse antes do tempo desejado. O sistema gel de colágeno associado com a biópsia foi mantido a $37^{\circ} \mathrm{C}$ durante $3 \mathrm{~h}$, a fim de induzir a polimerização do colágeno. Ao todo foram preparadas 54 placas contendo o sistema gel de colágeno/biópsia de pele, as quais foram nomeadas seguindo as condições escolhidas para o estudo, sendo: CT - Controle (somente o gel de colágeno), G1 - Nanoemulsão sem o fármaco, G2 - Nanoemulsão ClAlPc na ausência de estímulo luminoso, G3 - Nanoemulsão ClAlPc + luz $\left(70 \mathrm{~mJ} / \mathrm{cm}^{2}\right)$, G4 Nanoemulsão ClAlPc + luz $\left(140 \mathrm{~mJ} / \mathrm{cm}^{2}\right), \mathbf{G 5}$ - Nanoemulsão ClAlPc + luz $\left(700 \mathrm{~mJ} / \mathrm{cm}^{2}\right)$, G6 - Luz $\left(70 \mathrm{~mJ} / \mathrm{cm}^{2}\right), \mathbf{G 7}-\operatorname{Luz}\left(140 \mathrm{~mJ} / \mathrm{cm}^{2}\right)$ e $\mathbf{G 8}-\operatorname{Luz}\left(700 \mathrm{~mJ} / \mathrm{cm}^{2}\right)$.

A escolha das doses de luz, bem como a concentração do fármaco fotossensibilizante e o tempo de incubação com o fármaco foi feita baseada em trabalhos prévios do grupo (BARBUGLI, P. A., 2010; PRIMO, F. L., 2009; SIMIONI, A. R., 2009). Em trabalho prévio (BARBUGLI, P. A., 2010), o fármaco fotossensibilizante ClAlPc foi encapsulado em vesículas lipossomais. Foi determinada uma faixa de concentração do fármaco, estabelecendo-se a concentração de $0,29 \mu \mathrm{g} \mathrm{mL}^{-1}$ (ou $0,5 \mu \mathrm{M}$ ) como a que não causou a morte celular após $1 \mathrm{~h}$ de incubação com o fármaco $\mathrm{ClAlPc}$ em células metastáticas de melanoma humano. Além disso, no mesmo trabalho foram montados modelos de cultura com fibroblastos dermais em gel de colágeno, os quais foram submetidos a tratamentos com a formulação ClAlPc lipossomal e irradiação com laser nas doses de 70, 140 e $700 \mathrm{~mJ} / \mathrm{cm}^{2}$, seguindo uma sequência de ações pré-estabelecidas 


\subsubsection{Tratamento com a formulação de ftalocianina e irradiação das placas}

Após o período de polimerização, os géis de colágeno foram cobertos com meio DMEM $10 \%$ e as placas mantidas em incubadora a $37^{\circ} \mathrm{C}$, sendo posteriormente o meio trocado para DMEM 3\%, seguindo as condições pré-estabelecidas. Nas placas do grupo G1, o meio adicionado continha $20 \%$ da nanoemulsão sem o fármaco. Somente nas placas pertencentes aos grupos G2, G3, G4 e G5, a concentração de ftalocianina presente no meio foi de 7,5 $\mu \mathrm{M}$. Nas demais, o meio adicionado não continha o fármaco.

O tempo de incorporação do fármaco na incubadora foi de 20 a $40 \mathrm{~min}$, a $37^{\circ} \mathrm{C}$ e fluxo de $5 \%$ de $\mathrm{CO}_{2}$ (condições da incubadora). Em seguida, o meio foi trocado e as biópsias foram irradiadas com laser de diodo (na potência de 0,67 W, comprimento de onda de $670 \mathrm{~nm}$ e feixe óptico de $1 \mathrm{~cm}$ ) nas diferentes doses de energia selecionadas. No final da irradiação, retirou-se o meio de todas as placas e completou-as com $2 \mathrm{~mL}$ de meio DMEM 10\%. Os géis foram mantidos na incubadora, nas mesmas condições anteriores, por diferentes períodos de incubação: a primeira metade foi retirada após 7 dias de tratamento e a segunda após 14 dias. Dessa forma, pode-se observar a influência da TFD na produção e restauração da rede de elastina e colágeno da pele em diferentes períodos de tratamento. As amostras de meio de cultura aliquotadas de cada placa foram congeladas a $-70^{\circ} \mathrm{C}$ e as biópsias recolhidas ficaram mantidas em solução de formaldeído $4 \%$ para fixação. A Figura 8 ilustra as principais etapas desde o preparo dos géis de colágeno contendo as biópsias de pele até a irradiação com laser. 


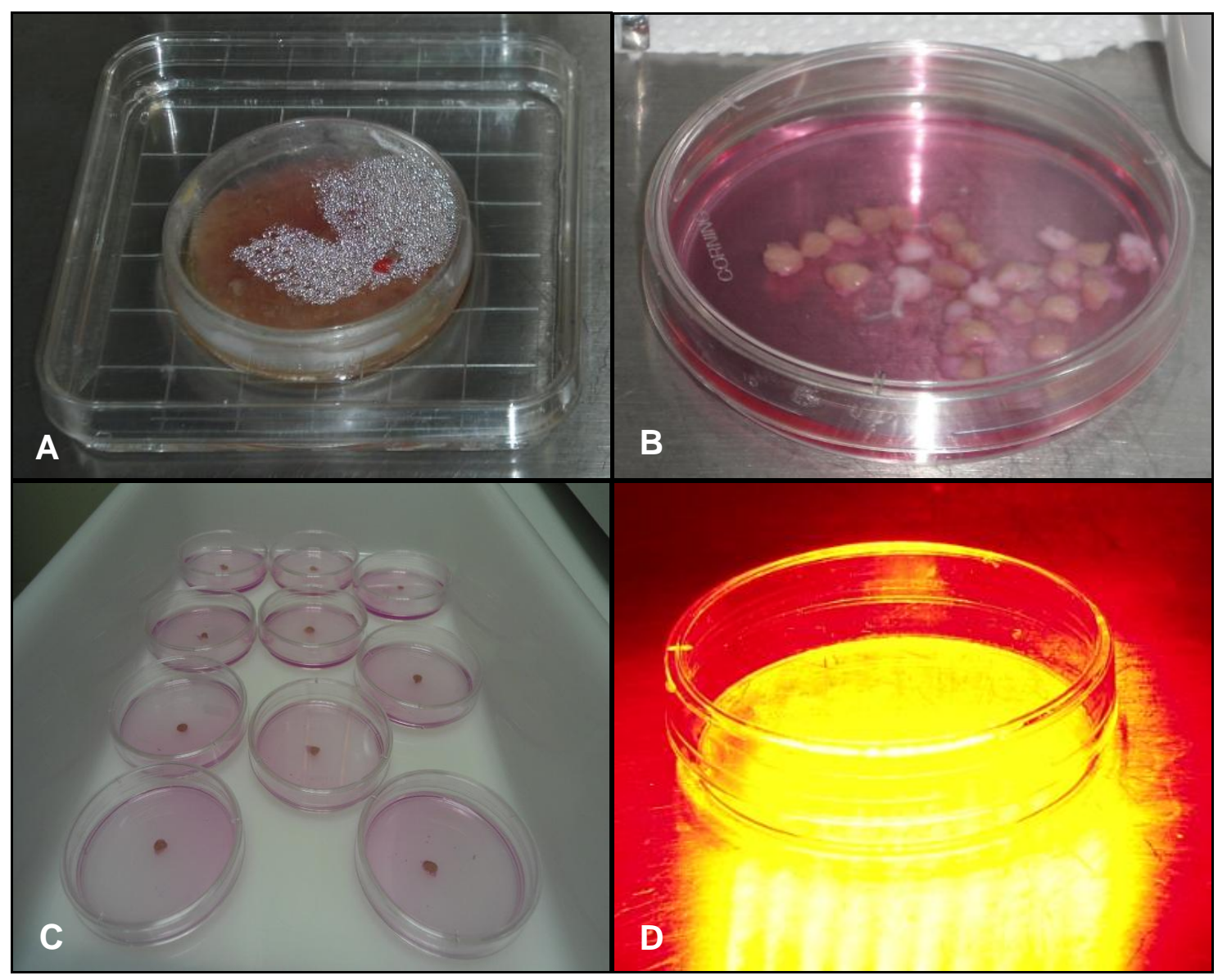

Figura 8. Principais etapas do experimento com biópsias de explants de pele: A) Fragmento de pele humana mantido em meio DMEM para realização do corte das biópsias; B) Biópsias de pele cortadas utilizando o punch e mantidas em meio DMEM; C) Placas de Petri contendo o gel de colágeno e as biópsias de pele; D) Irradição das placas com laser de $670 \mathrm{~nm}$ após tratamento com cloro alumínio ftalocianina.

\subsubsection{Fixação das biópsias e análise histológica}

No final de cada sequência de explants, as biópsias foram fixadas por $24 \mathrm{~h} \mathrm{em}$ formaldeído $4 \%$, considerado como fixador universal. Tal procedimento teve como objetivo preservar a biópsia e facilitar a posterior coloração. As biópsias foram mantidas no refrigerador a $4^{\circ} \mathrm{C}$ até o processo de inclusão em parafina.

A inclusão em parafina tem como objetivo dar sustentação ao tecido mantendo juntas as células e estruturas intercelulares. Ela ocorre em 4 etapas: desidratação, diafanização, 
impregnação da parafina e inclusão. A desidratação deve ser gradual, sendo o álcool etílico o agente mais comumente utilizado neste processo, empregado numa série crescente $(70 \%$ $80 \%-90 \%-100 \%$ ) para se evitar a retração pronunciada do tecido ocasionando lesões estruturais da célula de caráter irreversível. Na etapa de diafanização deve-se trocar o álcool gradualmente por um solvente que solubiliza a parafina, no caso foi utilizado benzeno. Nesta etapa o tecido se encontra translúcido, o que mostra que a etapa de desidratação foi eficiente. Já no processo de impregnação pela parafina, as peças foram colocadas em recipientes de alumínio contendo parafina a $60^{\circ} \mathrm{C}$, sendo necessárias 2 trocas de recipiente até obter uma parafina pura. Finalmente, as biópsias foram incluídas em parafina, formando blocos.

Para a montagem das lâminas, as biópsias foram seccionadas em micrótomo manual. Duas seções de $5 \mu \mathrm{m}$ foram obtidas de cada bloco, sendo posteriormente dispostas em lâminas de vidro e coradas com Orceína (para a rede de elastina) e Picrosirius Red (rede de colágeno). Para cada coloração histológica, as amostras foram submetidas ao processo de desidratação da parafina, passando por banhos sucessivos de tolueno e etanol em concentrações decrescentes. Após este processo as lâminas foram coradas utilizando protocolos clássicos para cada tipo de coloração. Ao final das colorações, a parafina foi hidratada e as lâminas analisadas por microscopia.

Todo este procedimento foi realizado com o auxílio da técnica Vani Maria Alves do Laboratório de Histologia do Departamento de Biologia Celular e Molecular e Bioagentes Patogênicos da Faculdade de Medicina de Ribeirão Preto - USP, com o qual temos colaboração. 


\subsubsection{Doseamento de colágeno e elastina nas de biópsias de explants de pele}

As seções histológicas coradas (54 lâminas para cada coloração) foram analisadas em microscópio óptico da Carl Zeiss (Oberkochen, Alemanha), como descrito anteriormente na sessão 3.2. Para a análise de colágeno, as biópsias também foram visualizadas com luz polarizada, permitindo diferenciar os tipos de colágeno existentes devido à birrefringência dos mesmos.

Para a quantificação de colágeno e elastina foi utilizado o software AxioVision Release 4.8.2 da Carl Zeiss (Oberkochen, Alemanha), acoplado ao microscópio óptico. Este software possibilita a marcação por cor e posterior quantificação das áreas marcadas, conforme a estrutura de interesse, fornecendo parâmetros como "soma da área", "porcentagem de área", entre outros, para cada imagem analisada. Assim, utilizando-se o parâmetro "soma da área" foi possível relacionar e calcular o aumento ou redução percentual da quantidade de colágeno e elastina presente em cada imagem em relação à imagem do controle.

A Figura 9 mostra um exemplo de imagem após a marcação das áreas a serem quantificadas pelo software AxioVision Release 4.8.2.

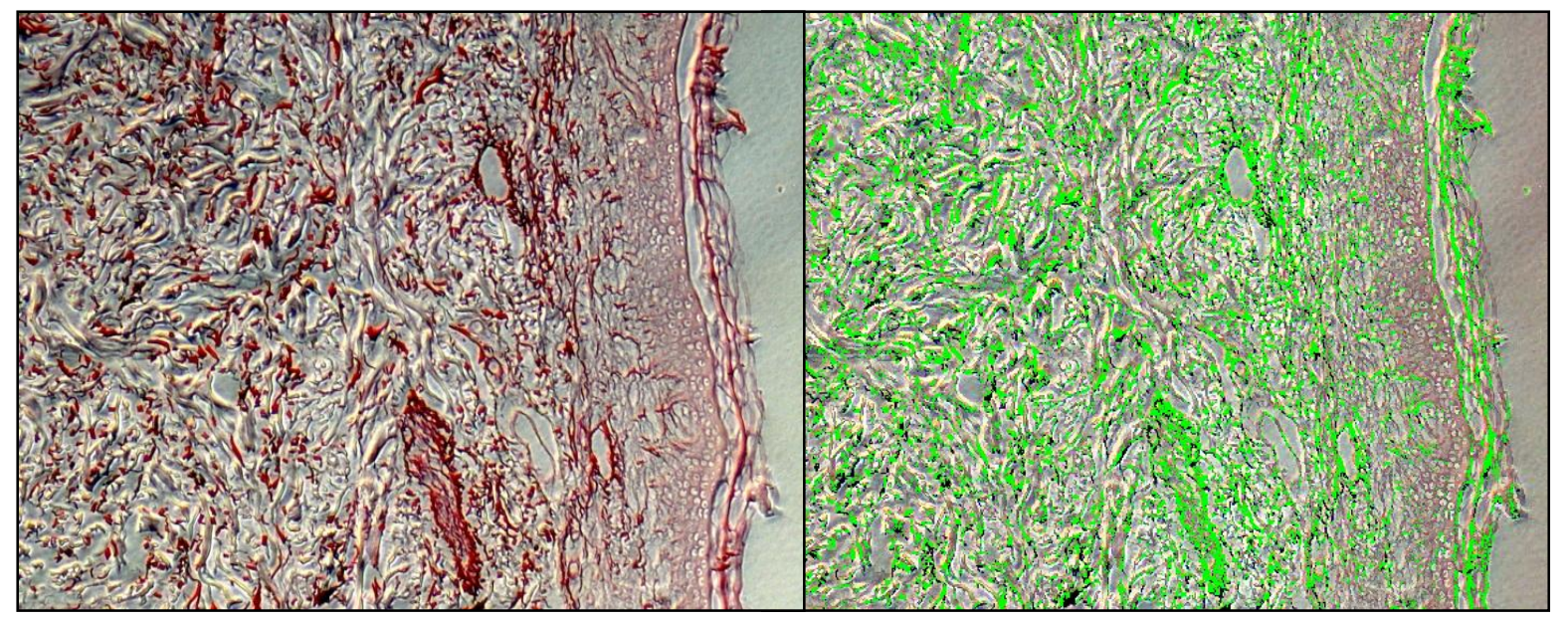

Figura 9. Marcação (verde) da rede de elastina (vermelho) de uma amostra de imagem, utilizando o software AxioVision Release 4.8.2 da Carl Zeiss acoplado ao microscópio óptico. 


\subsubsection{Avaliação da expressão das enzimas MMP-2 e MMP-9 por zimografia}

O estudo da expressão das metaloproteases MMP-2 e MMP-9, presentes no processo de cicatrização, foi realizado pela técnica de zimografia a partir dos meios coletados e aliquotados após os diferentes tempos de tratamento das biópsias de explants de pele (7 e 14 dias).

Foi elaborado um roteiro experimental, de forma que cada gel pudesse conter no mínimo uma amostra de cada condição avaliada no experimento. Assim, sabendo que cada condição foi avaliada em triplicata, foi necessário realizar 3 géis para as amostras tratadas por 7 dias e mais 3 géis para aquelas tratadas durante 14 dias após a irradiação das placas. Os meios recolhidos após o experimento foram nomeados, conforme mostra a Tabela I.

Tabela I. Nomenclatura das amostras de meio de cultura recolhidas após o experimento com biópsias de explants de pele e utilizadas nos estudos por zimografia.

\begin{tabular}{|c|c|c|c|c|c|c|c|}
\hline \multirow{2}{*}{$\frac{\text { Grupo }}{\text { CT }}$} & \multirow{2}{*}{$\begin{array}{c}\text { Condição } \\
\text { Controle }\end{array}$} & \multicolumn{3}{|c|}{ Dia 7} & \multicolumn{3}{|c|}{ Dia 14} \\
\hline & & 28 & 29 & 30 & 82 & 83 & 84 \\
\hline G1 & Formulação vazia* & 31 & 32 & 33 & 85 & 86 & 87 \\
\hline G2 & CIAIPc & 34 & 35 & 36 & 88 & 89 & 90 \\
\hline G3 & ClAIPc + $70 \mathrm{~mJ} / \mathrm{cm}^{2}$ & 37 & 38 & 39 & 91 & 92 & 93 \\
\hline G4 & $\mathrm{ClAlPc}+140 \mathrm{~mJ} / \mathrm{cm}^{2}$ & 40 & 41 & 42 & 94 & 95 & 96 \\
\hline G5 & $\mathrm{ClAIPc}+700 \mathrm{~mJ} / \mathrm{cm}^{2}$ & 43 & 44 & 45 & 97 & 98 & 99 \\
\hline G6 & $70 \mathrm{~mJ} / \mathrm{cm}^{2}$ & 46 & 47 & 48 & 100 & 101 & 102 \\
\hline G7 & $140 \mathrm{~mJ} / \mathrm{cm}^{2}$ & 49 & 50 & 51 & 103 & 104 & 105 \\
\hline G8 & $700 \mathrm{~mJ} / \mathrm{cm}^{2}$ & 52 & 53 & 54 & 106 & 107 & 108 \\
\hline
\end{tabular}

*Formulação que não contém o fármaco. 
Dessa forma, os géis foram elaborados seguindo a ordem proposta na Tabela II.

Tabela II. Ordem das amostras nos géis de zimografia segundo nomenclatura estabelecida

\begin{tabular}{cc|lllllllllll}
\hline \hline Gel & Dia & \multicolumn{10}{|c}{ Ordem das amostras } \\
\hline $\mathbf{1}$ & 7 & Rainbow & HT & 28 & 34 & 37 & 40 & 43 & 46 & 49 & 52 \\
$\mathbf{2}$ & 7 & Rainbow & HT & 29 & 35 & 38 & 41 & 44 & 47 & 50 & 53 \\
$\mathbf{3}$ & 7 & Rainbow & HT & 30 & 36 & 39 & 42 & 45 & 48 & 51 & 54 \\
$\mathbf{4}$ & 14 & Rainbow & HT & 82 & 88 & 91 & 94 & 97 & 100 & 103 & 106 \\
$\mathbf{5}$ & 14 & Rainbow & HT & 83 & 89 & 92 & 95 & 98 & 101 & 104 & 107 \\
$\mathbf{6}$ & 14 & Rainbow & HT & 84 & 90 & 93 & 96 & 99 & 102 & 105 & 108 \\
\hline \hline
\end{tabular}

*Marcador de peso molecular utilizado;

** Linhagem celular HT-1080 (fibrossarcoma humano), utilizada como padrão.

Previamente ao experimento, foram preparadas todas as soluções e tampões utilizados. Inicialmente foi feita a montagem do sistema Bio-rad do tipo Protean III, como descrito na sessão 3.2, dentro das normas apresentadas pelo fabricante. Após montagem do sistema iniciou-se a preparação do gel de corrida, permitindo obter 4 géis. Desta forma, $20 \mathrm{mg}$ de gelatina foram inicialmente dissolvidos em $9,7 \mathrm{~mL}$ de água destilada, em banho de água a $60^{\circ} \mathrm{C}$. A esta mistura foi adicionado (na sequência) tampão Tris $1,5 \mathrm{M} \mathrm{pH} \mathrm{8,8,} \mathrm{SDS} 10 \%$, Acrilamida/bis 40\%, APS $10 \%$ (Persulfato de amônio pré-aliquotado) e N,N,N,N-Tetrametil etileno diamina (TEMED 5\%). Depois de colocar o gel de corrida nas placas suportes (até 1 cm abaixo do nível superior), completou-as com água destilada e iniciou-se o processo de polimerização. Após este processo, preparou-se o gel de aplicação de maneira análoga ao gel de corrida, porém com proporções diferentes de cada solução. Após a remoção da água colocada sobre as placas, foi adicionado o gel de aplicação, seguido imediatamente da 
aplicação dos marcadores de canais de 1,0 mm de largura, contendo 10 aplicadores. O sistema foi deixado polimerizar por mais 15 minutos.

As amostras a serem aplicadas foram preparadas pela mistura de proporções equivalentes de tampão de amostra (SDS 10\%, Tris-HCl pH 6,8 e corante azul de bromofenol $0,1 \%)$ e as amostras de meio isoladas, previamente aliquotadas, e estocadas durante cada experimento. Desta mistura homogeneizada, aplicou-se $5 \mu \mathrm{L}$ por poço em cada gel. Utilizouse uma suspensão de células de fibrossarcoma humano (HT-1080), para produção do meio de cultura utilizado como padrão para as bandas de metaloproteases do tipo MMP-9 e MMP-2, bem como um marcador de peso molecular numa ampla faixa (Rainbow).

Uma solução tampão pH 8,0 contendo Tris, glicina e SDS (tampão de corrida) foi preparada em quantidade apropriada de maneira a cobrir as cubas até a borda superior. Após polimerização completa, o marcador de canal foi retirado e as amostras aplicadas sobre o gel imerso no meio de corrida. Uma vez completo o gel, iniciou-se a eletroforese com aplicação inicial de $70 \mathrm{~V}$ por 30 min seguidos de $90 \mathrm{~V}$ por aproximadamente $2 \mathrm{~h}$. Terminada a eletroforese, os géis passaram por 2 lavagens seguidas de 30 min cada com solução de TritonX 100 2,5\% para eliminar o SDS do gel e depois com água destilada em abundância para remoção de qualquer traço de detergente. Ao final das lavagens, os géis foram incubados a $37^{\circ} \mathrm{C}$ com o tampão de incubação ( $\left.\mathrm{pH} 8,0 ; \mathrm{NaN}_{3} ; \mathrm{CaCl}_{2} 5,0 \mathrm{mmol} / \mathrm{L}\right)$ por $24 \mathrm{~h}$.

Após o período de aproximadamente $24 \mathrm{~h}$, o meio de incubação foi trocado e adicionou-se a solução de coloração (azul de Coomassie R250 a 0,5\%; ácido acético a 10\%; isopropanol a 20\%), seguida do meio de revelação (ácido acético a 10\% e isopropanol a 20\%). Os géis foram deixados por $30 \mathrm{~min}$ em cada meio e finalmente armazenados nas placas contendo água destilada. A Figura 10 representa um esquema de algumas etapas do processo de zimografia, mostrando os equipamentos utilizados. 


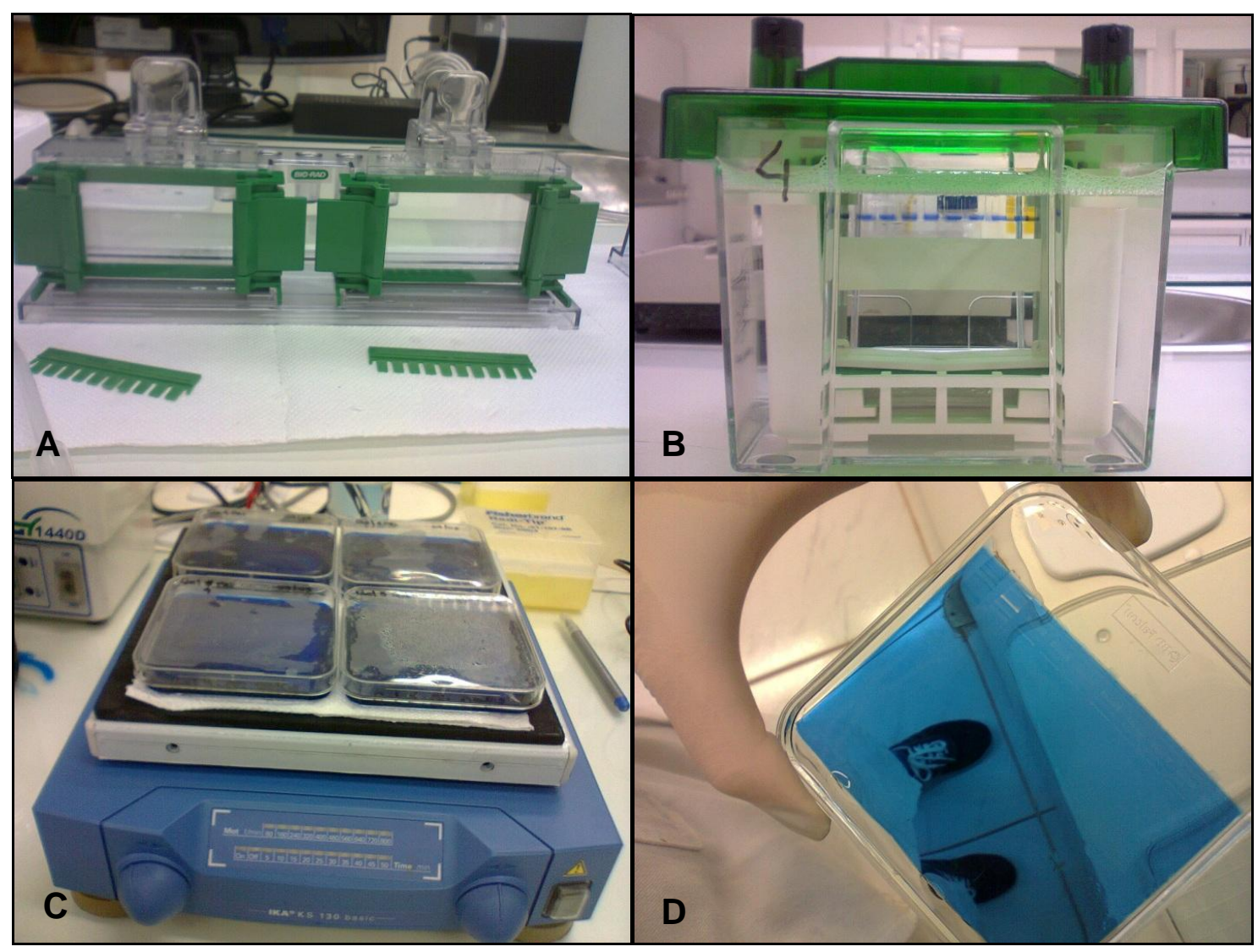

Figura 10. Etapas do processo de zimografia: A) Montagem dos géis; B) Amostras aplicadas no gel inserido na cuba de corrida; C) Revelação dos géis com solução de Azul de Coomassie; D) Gel finalizado.

\subsubsection{Quantificação dos géis de zimografia}

O registro fotográfico das bandas foi realizado utilizando o sistema de aquisição de imagens da UVITec Cambridge, modelo UVIdoc HD2/20M, com câmera de 1.4 megapixels e câmara ultravioleta. Já a quantificação das imagens foi feita através do software GeneTools da Syngene, como descrito no item 3.2.

Para a quantificação das bandas, primeiramente, foi feita uma inversão de pixels da imagem do gel, assim os pontos brancos tornaram-se pretos, o que facilitou a visualização e quantificação da intensidade de cor (Figura 11). Em seguida, foi quantificada a intensidade das bandas referentes aos diferentes grupos em relação à intensidade da banda referente ao 
controle. Deste modo, sabendo-se que os géis foram feitos em triplicata, para cada condição experimental, obteve-se 3 resultados de intensidade de banda para cada grupo analisado. A média aritmética desses resultados foi realizada e aplicou-se o pós-teste Turkey, obtendo assim o aumento na expressão das metaloproteases MMP-2 e MMP-9 após 7 e 14 dias das biópsias de explants de pele submetidas ao tratamento com fármaco fotossensibilizante e irradiação em diferentes doses de luz.

A)

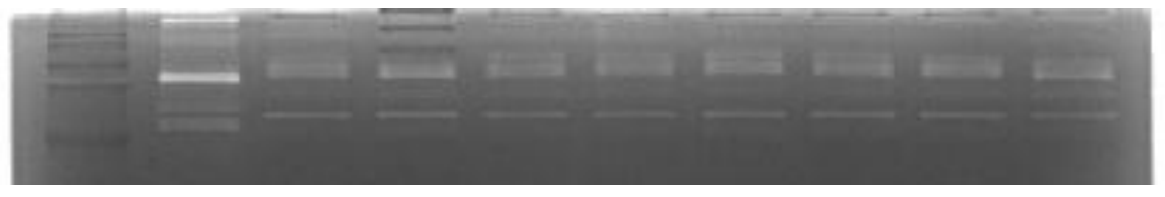

B)

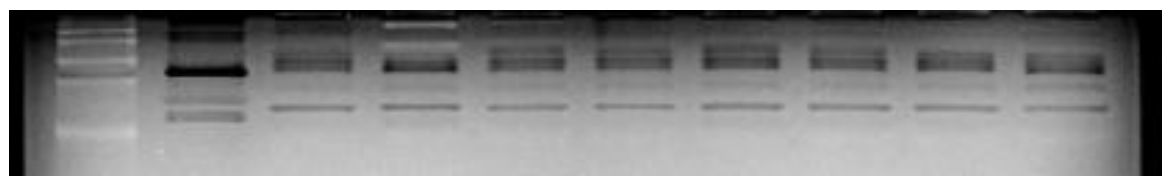

Figura 11. A) Imagem obtida de um gel de zimografia utilizando-se o sistema de aquisição de imagens com câmara ultravioleta; B) Imagem com inversão de pixels.

\subsection{Análise estatística e softwares}

Os valores obtidos experimentalmente foram calculados empregando-se o programa Excel Microsoft 2010 e as análises estatísticas foram realizadas no programa Prism 3.0 através dos testes de análise de variância (One-way Anova), sendo Turkey o pós-teste aplicado. Todos os espectros obtidos foram plotados utilizando-se o software Igor-Pro® Wavemetrics $3.16 \beta 01$ (versão científica). 


\section{Resultados e Discussão}

\subsection{Determinação do tamanho das gotículas, índice de polidispersão e potencial Zeta da nanoemulsão contendo ClAIPc}

As medidas do diâmetro médio das gotículas e do índice de polidispersão, obtidas por espalhamento dinâmico de luz, e do potencial Zeta, como descrito no item 3.3.2.1, estão contidas na Tabela III.

Tabela III. Parâmetros físico-químicos para a nanoemulsão contendo ClAlPc

\begin{tabular}{cccc}
\hline & $\begin{array}{c}\text { Diâmetro } \\
\text { médio das } \\
\text { gotículas }(\mathrm{nm})\end{array}$ & IPd & $\begin{array}{c}\text { Potencial } \\
\text { Zeta } \\
(\mathrm{mV})\end{array}$ \\
\hline $\begin{array}{c}\mathrm{ClAlPc} \\
(0,05 \mathrm{mg} \\
\left.\mathrm{mL}^{-1}\right)\end{array}$ & $200,7 \pm 10,4$ & $0,16 \pm 0,04$ & $-45,4 \pm 6,8$ \\
\hline Os resultados estão expressos em média \pm desvio padrão dos ensaios realizados.
\end{tabular}

O diâmetro médio encontrado para as gotículas que formam a nanoemulsão foi de aproximadamente $200 \mathrm{~nm}$. Há uma discussão que envolve faixas de tamanho de partícula adequadas para determinados sistemas de liberação de fármacos. No caso da nanoemulsão, a faixa de $200 \mathrm{~nm}$ é adequada, já que a via de administração dessa formulação é tópica, não ocasionando problemas como obstrução de vasos sanguíneos, agregação das partículas, entre outros.

O índice de polidispersão (IPd) é um indicativo da distribuição de tamanho de uma formulação. Como é possível observar na Tabela III, a formulação apresentou um IPd abaixo 
de 0,5 , confirmando a capacidade do método de preparo de nanoemulsões em produzir formulações homogêneas (SIQUEIRA-MOURA, 2011).

O potencial Zeta apresentou um valor médio de $-45,4 \mathrm{mV}$. Este valor demonstrou um potencial superficial predominantemente negativo, resultado do balanço das cargas superficiais. Sabe-se que valores muito positivos ou muito negativos de potencial Zeta (geralmente maiores que $+30 \mathrm{mV}$ ou menores que $-30 \mathrm{mV}$ ) são indicadores de sistemas termodinamicamente estáveis, pois quanto mais cargas somente positivas ou somente negativas estiverem na superfície das partículas que compõem o sistema, maior é a repulsão entre elas, ou seja, mais dispersas elas se encontram no sistema, evitando assim a formação de agregados, ou aglomerados, que promovem a desestabilização desse sistema. Dessa forma, o valor médio de $-45,4 \mathrm{mV}$ encontrado para o potencial Zeta está adequado para uma formulação estável, e consequentemente para o seu posterior uso.

\subsection{Estudo de estabilidade termodinâmica da nanoemulsão contendo ClAIPc}

A estabilidade termodinâmica é um fator chave no desenvolvimento de um sistema de liberação de fármacos. O monitoramento da estabilidade físico-química da formulação foi investigado avaliando-se o tamanho das gotículas, potencial Zeta e índice de polidispersão da formulação durante 3 meses, com estocagem a $4^{\circ} \mathrm{C}$. A Figura 12 apresenta as medidas de tamanho das gotículas, índice de polidispersão e potencial Zeta, mostrando o perfil obtido. 


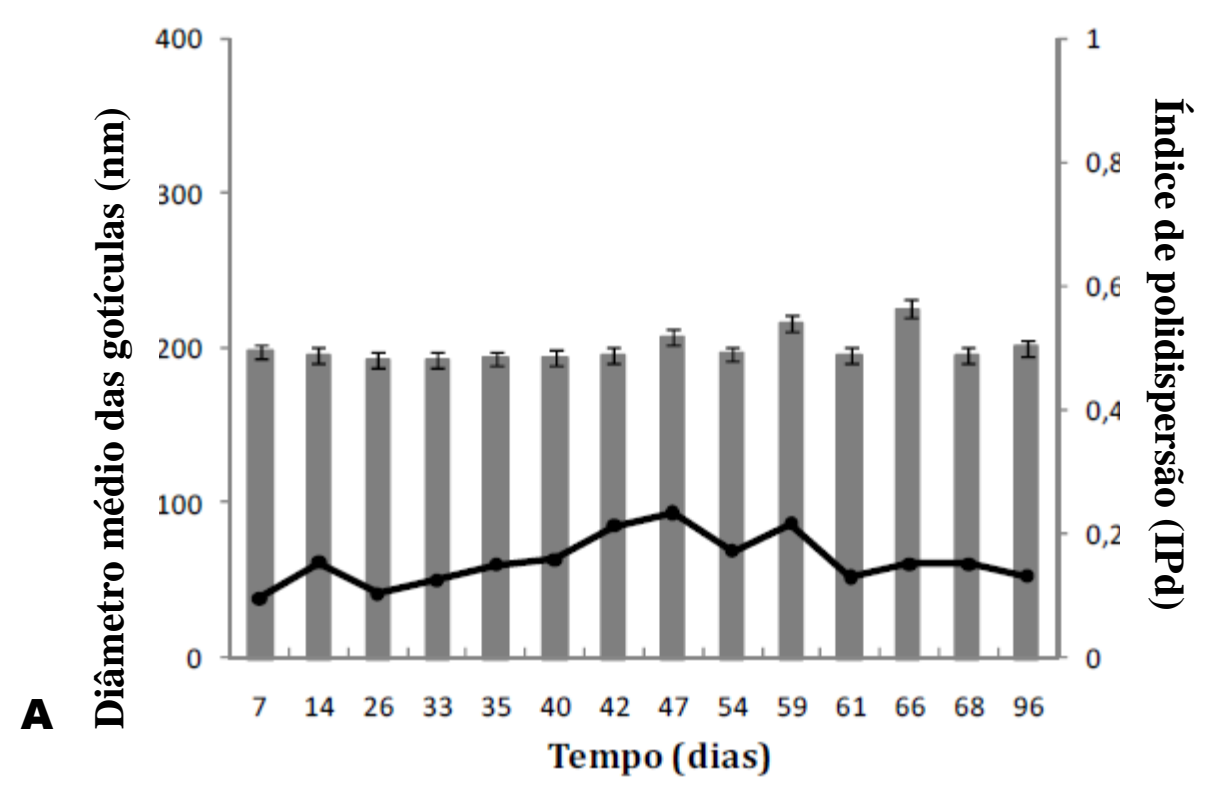

Tempo (dias)

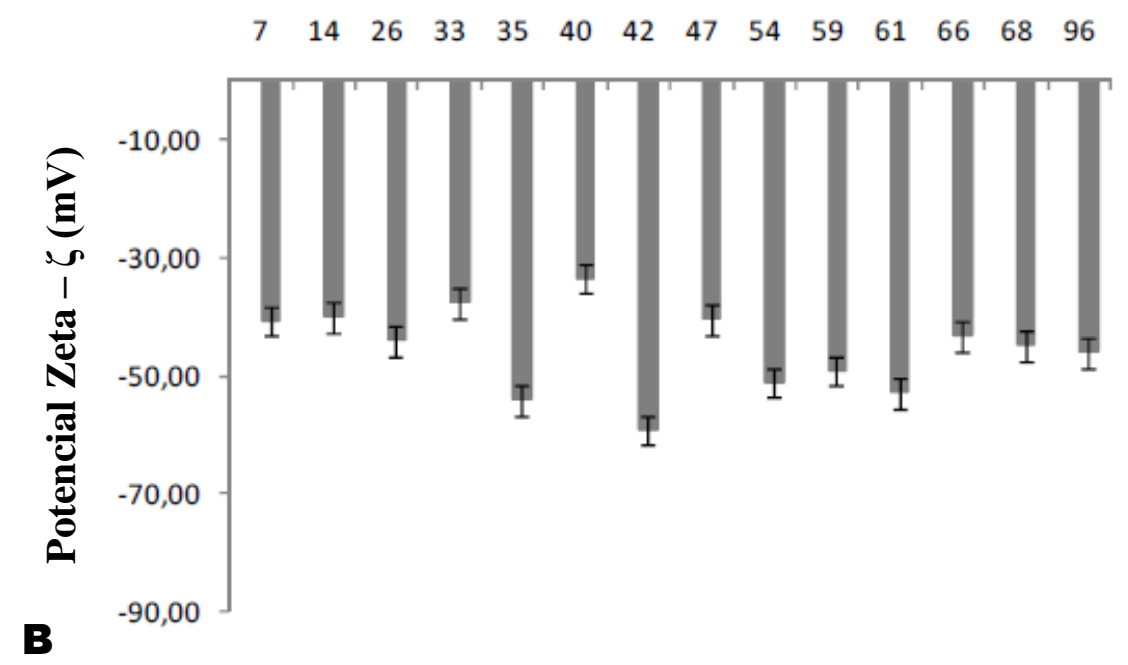

Figura 12. Estudo de estabilidade físico-química monitorando-se o tamanho médio das gotículas, o índice de polidispersão (A) e o potencial Zeta (B) em função do tempo para a nanoemulsão contendo ClAlPc. Os resultados são expressos como média \pm desvio padrão.

Os resultados demonstraram que o sistema de liberação contendo o fármaco ClAlPc apresentou uma estabilidade termodinâmica apropriada, com tamanho médio das gotículas de 200 nm, como mostra a Tabela III. O índice de polidispersão não apresentou grandes variações durante o tempo avaliado, o que condiz com sistemas homogêneos monodispersos. O mesmo ocorreu para o potencial Zeta, o que mostra que o sistema é estável durante o 
período avaliado, do ponto de vista que não houve variação significativa nas cargas superficiais das gotículas.

\subsection{Doseamento da ClAIPc na nanoemulsão}

O doseamento da ClAlPc na nanoemulsão foi realizado seguindo um método validado pelo trabalho do grupo descrito por SIQUEIRA-MOURA et al., 2010, através da determinação dos espectros de absorção na região do UV-Vis e de fluorescência da ClAlPc, como descrito no item 3.3.2.3.

As Figuras 13 A e C apresentam os espectros de absorção e de fluorescência da ClAlPc, respectivamente. O espectro de absorção de ftalocianinas é composto por duas principais bandas, as quais se encontram na região ultravioleta $(300-350 \mathrm{~nm})$, conhecida como Banda-B ou Soret, e na região do visível $(600$ - $700 \mathrm{~nm})$, conhecida como banda-Q (SIQUEIRA-MOURA et al., 2010). Ambas as bandas estão associadas às transições $\pi$ - $\pi^{*}$ correspondentes a diversos modos vibracionais do anel. Fatores que influenciam a posição dessas bandas para as diferentes ftalocianinas são o átomo central, o estado de oxidação do metal, spin, substituintes do anel, entre outros. O espectro de absorção da ClAlPc mostrado na Figura 13 A apresenta as típicas bandas Soret e banda-Q, características de metaloftalocianinas, com máximo de absorção em $670 \mathrm{~nm}$.

O espectro de fluorescência, obtido de SIQUEIRA-MOURA et al., 2010 e mostrado na Figura 13 C, demonstrou uma alta intensidade de fluorescência, com comprimento de onda de excitação em $615 \mathrm{~nm}$, e emissão em $674 \mathrm{~nm}$, como descrito na literatura (NUNES , SGUILLA e TEDESCO, 2004; TEDESCO , ROTTA e LUNARDI, 2003). 

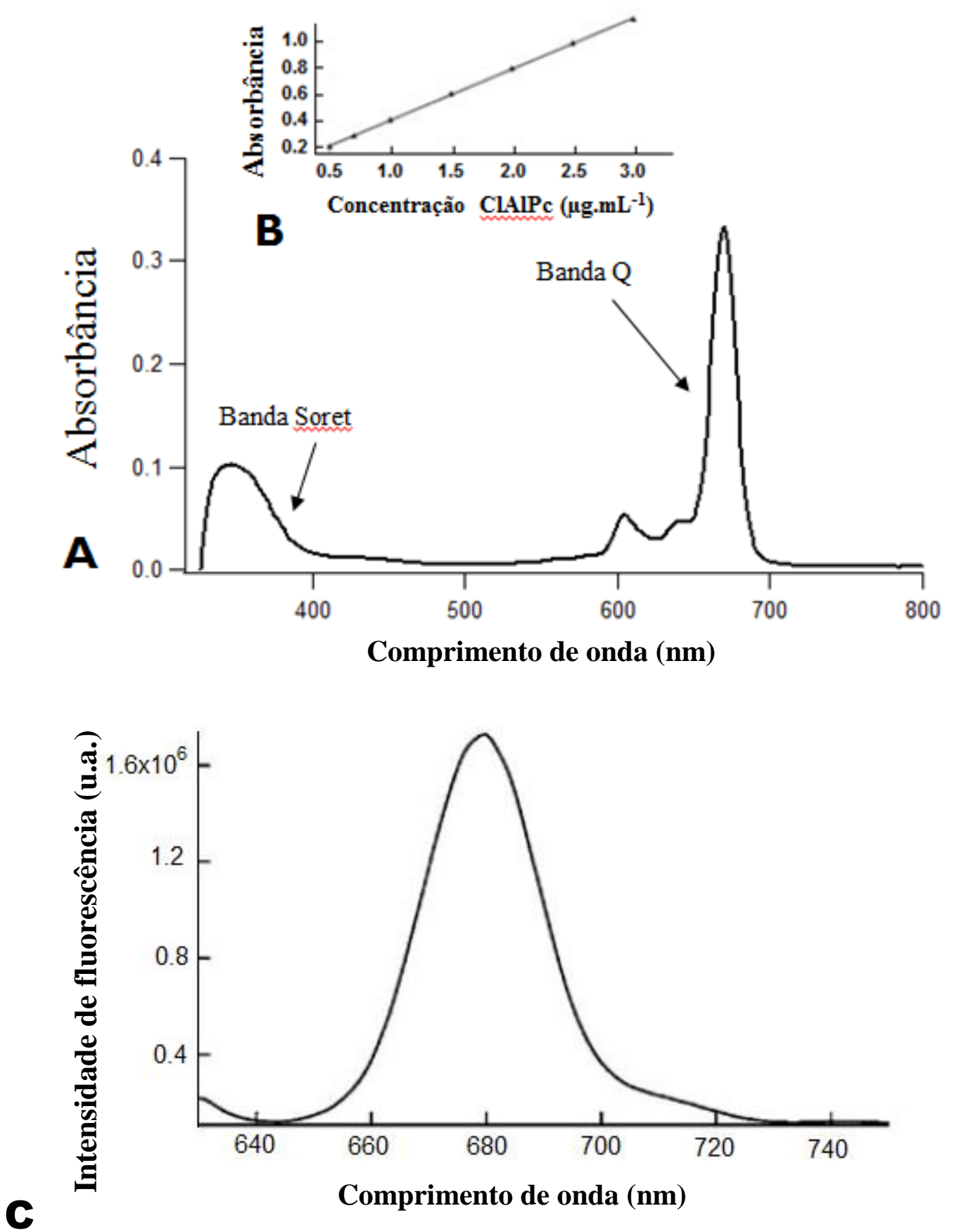

Figura 13. (A) Espectro de absorção na região do UV-Vis da solução de ClAlPc em acetonitrila, (B) Curva de calibração da ClAlPc em acetonitrila, Absorbância $=0.3829$ X [ClAlPc, concentração em $\mu \mathrm{g} \mathrm{mL}^{-1}$ ] + $0.0126(\mathrm{R}=0,9992)$ (SIQUEIRA-MOURA et al., 2010) e (C) Espectro de fluorescência da solução de ClAlPc em acetonitrila com excitação em 615 nm (SIQUEIRA-MOURA et al., 2010). 
O cálculo da quantidade de ClAlPc presente na formulação foi realizado utilizando-se uma curva de calibração para este fármaco, Figura 13 B, obtida exatamente nas mesmas condições e equipamentos os quais foi obtido o espectro de absorção da ftalocianina, como mostrado em SIQUEIRA-MOURA et al., 2010. Os cálculos apontaram uma concentração final de aproximadamente $25 \mu \mathrm{g} \mathrm{mL} \mathrm{m}^{-1}$ de cloro alumínio ftalocianina na solução estoque, os quais condizem com o fator de diluição de $50 \%$ da concentração de ftalocianina que foi adicionada durante o preparo da formulação, que se deve à diluição da fase orgânica, que contém o fármaco, pela fase aquosa no processo de emulsificação.

\subsection{Análise histológica}

A pele consiste de um número de camadas com funções distintas e propriedades ópticas distintas. Quando luz branca incide sobre a pele, ela penetra pelas camadas superficiais e um pouco é absorvida, porém a maior parte é reemitida e pode ser registrada por uma câmera (CLARIDGE et al., 2003).

O procedimento mais usado no estudo de tecidos é a preparação de cortes histológicos que podem ser estudados com a ajuda de um microscópio, como é o caso do procedimento escolhido para a análise das biópsias de explants de pele. No microscópio de luz (também chamado de microscópio óptico) a imagem foi examinada pela passagem de um feixe de luz transmitido através do corte. Considerando que tecidos e órgãos são normalmente espessos demais para permitir a passagem de um feixe de luz, eles foram seccionados a fim de se obter cortes delgados. Para isso, o tecido foi imerso numa solução fixadora, formaldeído a 4\%, para imobilizar as proteínas. Em seguida, água foi removida do tecido através de banhos com álcool, o tecido foi posteriormente diafanizado com solvente orgânico. O tecido foi então incluído em meio firme, parafina, para se obter cortes finos por meio de um instrumento 
chamado micrótomo. Os cortes foram corados para permitir que se observassem os detalhes dos tecidos. Desta maneira, é possível estudar essas estruturas por longos períodos sob diversas condições fisiológicas ou experimentais (JUNQUEIRA e CARNEIRO, 2004)

\subsubsection{Análise para elastina}

As imagens obtidas após as análises das lâminas contendo as biópsias de pele póscoloração, como descrito no item 3.3.7, foram agrupadas segundo o tipo de estrutura a ser analisada. A Figura 14 apresenta a imagem obtida da amostra sem tratamento (controle) corada com Orceína, com aumento de 10x. Através da Figura 14 é possível observar as estruturas da pele, sendo a primeira camada distinguível a epiderme e logo após a derme.

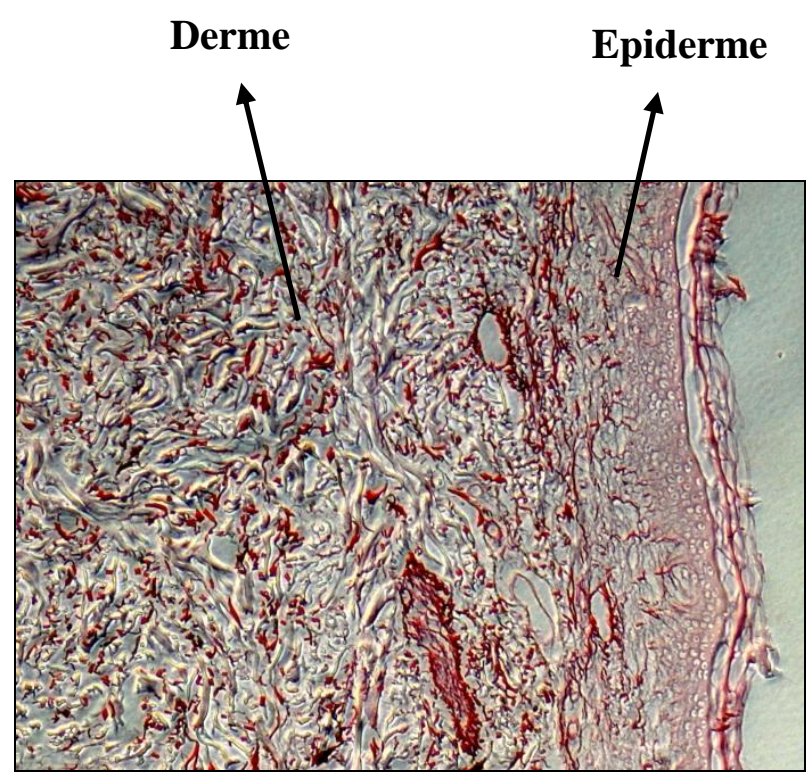

Figura 14. Análise histológica da biópsia de explant de pele sem tratamento (controle) e corada com Orceína, evidenciando as camadas da pele: epiderme e derme. 
A Orceína é um corante ácido com baixa solubilidade em água e principalmente solúvel em etanol. Esse corante é tipicamente utilizado por histologistas e sua coloração evidencia as redes de elastina presentes na derme. A Figura 15 apresenta a fórmula estrutural da Orceína.<smiles></smiles>

Figura 15. Molécula de Orceína

Fonte: http://commons.wikimedia.org/wiki/File:Orcein.png

A elastina é formada após a polimerização de múltiplas moléculas precursoras tropoelastina, sintetizadas por fibroblastos dérmicos, secretadas e depois polimerizadas na elastina insolúvel. A elastina madura insolúvel, formada no corpo humano quase que exclusivamente durante os períodos de gestação e infância, é metabolicamente inerte e o elemento mais duradouro da matriz extracelular (GOLINSKI et al., 2011; GUNDIAH , RATCLIFFE e PRUITT, 2007; MITTS et al., 2010).

Assim como para a amostra sem tratamento, foram obtidas imagens de todas as amostras de pele obtidas após o experimento, variando-se o tipo de tratamento (com fármaco fotossensibilizante e luz ou somente com luz), a dosagem de luz $\left(70,140\right.$ e $\left.700 \mathrm{~mJ} / \mathrm{cm}^{2}\right)$ e o período de tratamento (7 e 14 dias). As imagens mais relevantes estão mostradas nas Figuras 16 e 17 , porém em todas as imagens obtidas foram observadas as redes de elastina presentes na derme, algumas em maior quantidade e mais intensidade do que outras, dependendo do tipo de tratamento realizado. A fim de quantificar essa diferença na intensidade das fibras elásticas foi realizada uma análise quantitativa delimitando as áreas onde predominavam as fibras elásticas, conforme descrito no item 3.3.7. As Figuras 16 e 17 apresentam essa análise 
quantitativa percentual das áreas onde estão presentes as fibras elásticas, para dois períodos de tratamento distintos: 7 e 14 dias. Buscando um melhor entendimento, as figuras foram agrupadas de acordo com o tipo de tratamento. Em ambas as figuras estão evidenciadas as imagens das amostras cujos resultados foram mais relevantes, a fim de confirmar a análise quantitativa.

A Figura 16 apresenta uma comparação entre os resultados das amostras que receberam tratamento somente com luz, em diferentes doses. A análise histomorfológica apontou um aumento na rede de elastina das amostras analisadas após 14 dias de tratamento, o que não foi verificado após 7 dias de tratamento, sendo o grupo irradiado com luz na dose de $70 \mathrm{~mJ} / \mathrm{cm}^{2}(\mathrm{G} 6)$ o que apresentou melhores resultados.

A Figura 17 mostra uma comparação entre os grupos que receberam tratamento com o fármaco fotossensibilizante e luz, em diferentes doses. Assim como na Figura 16, observa-se na Figura 17 que as amostras analisadas após 14 dias do tratamento apresentaram melhores resultados, notando-se um aumento da rede de elastina em relação ao controle (amostra sem tratamento), como pode ser visualizado. Dentre os grupos comparados, o que apresentou a melhor combinação foi o grupo tratado com a cloro alumínio ftalocianina e irradiado com a dose $140 \mathrm{~mJ} / \mathrm{cm}^{2}$ (G4), após 14 dias de tratamento. Observou-se que doses maiores de irradiação $\left(\mathrm{ClAlPc}+700 \mathrm{~mJ} / \mathrm{cm}^{2}\right)$ provocaram a degradação da rede de elastina, como evidenciado pelas imagens de microscopia das biópsias de pele. 

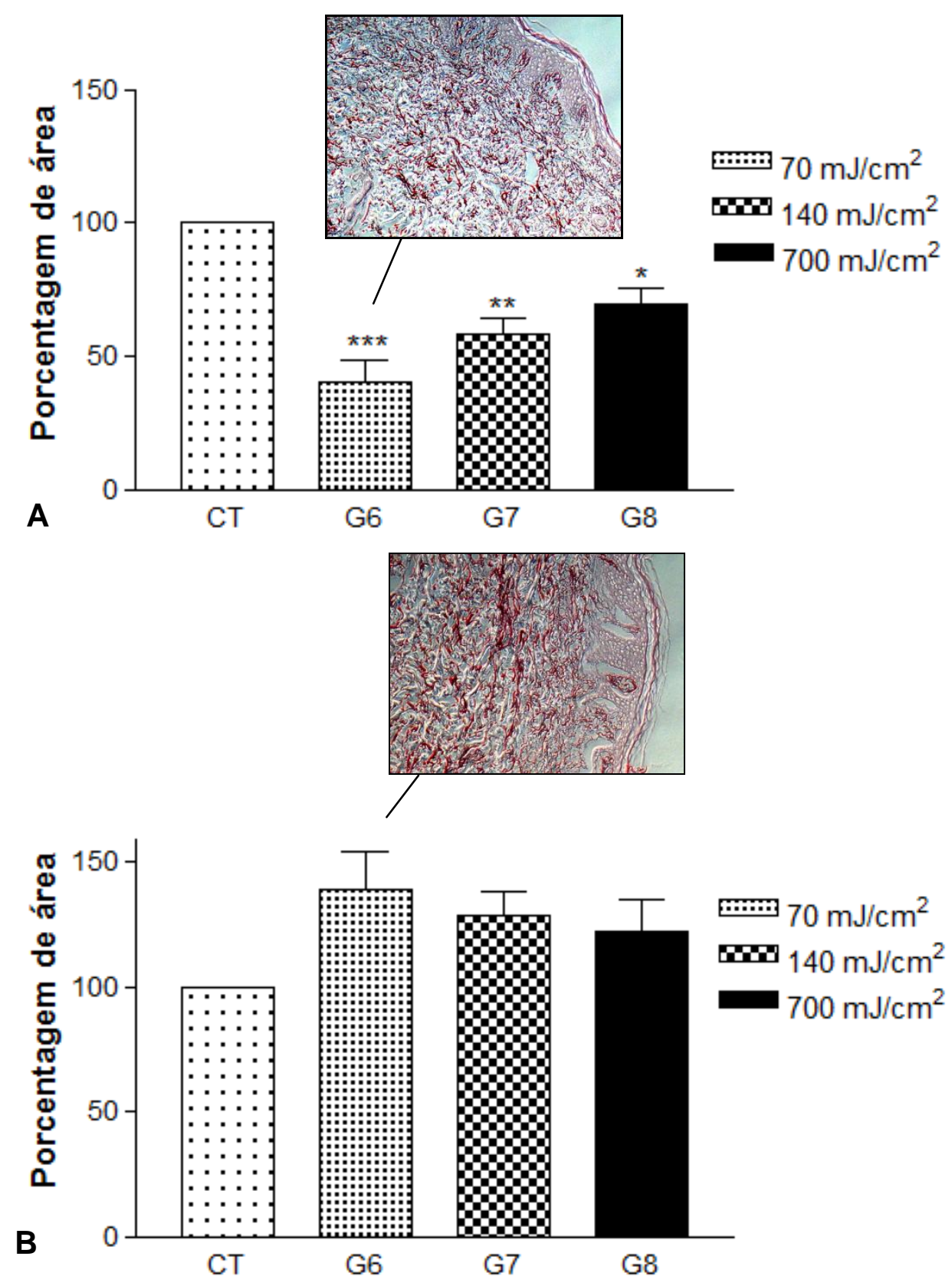

Figura 16. Comparação entre as porcentagens de área de elastina das biópsias de pele irradiadas por laser de diodo $(670 \mathrm{~nm})$ em diferentes doses de 70,140 e $700 \mathrm{~mJ} / \mathrm{cm}^{2}$ e incubadas por diferentes períodos: A) 7 dias; B) 14 dias. Os resultados são expressos como média \pm desvio padrão, sendo $* * *(\mathrm{P}<0,001), * *(\mathrm{P}<0,01)$ e $*(\mathrm{P}<0,05)$ estatisticamente significativos. 

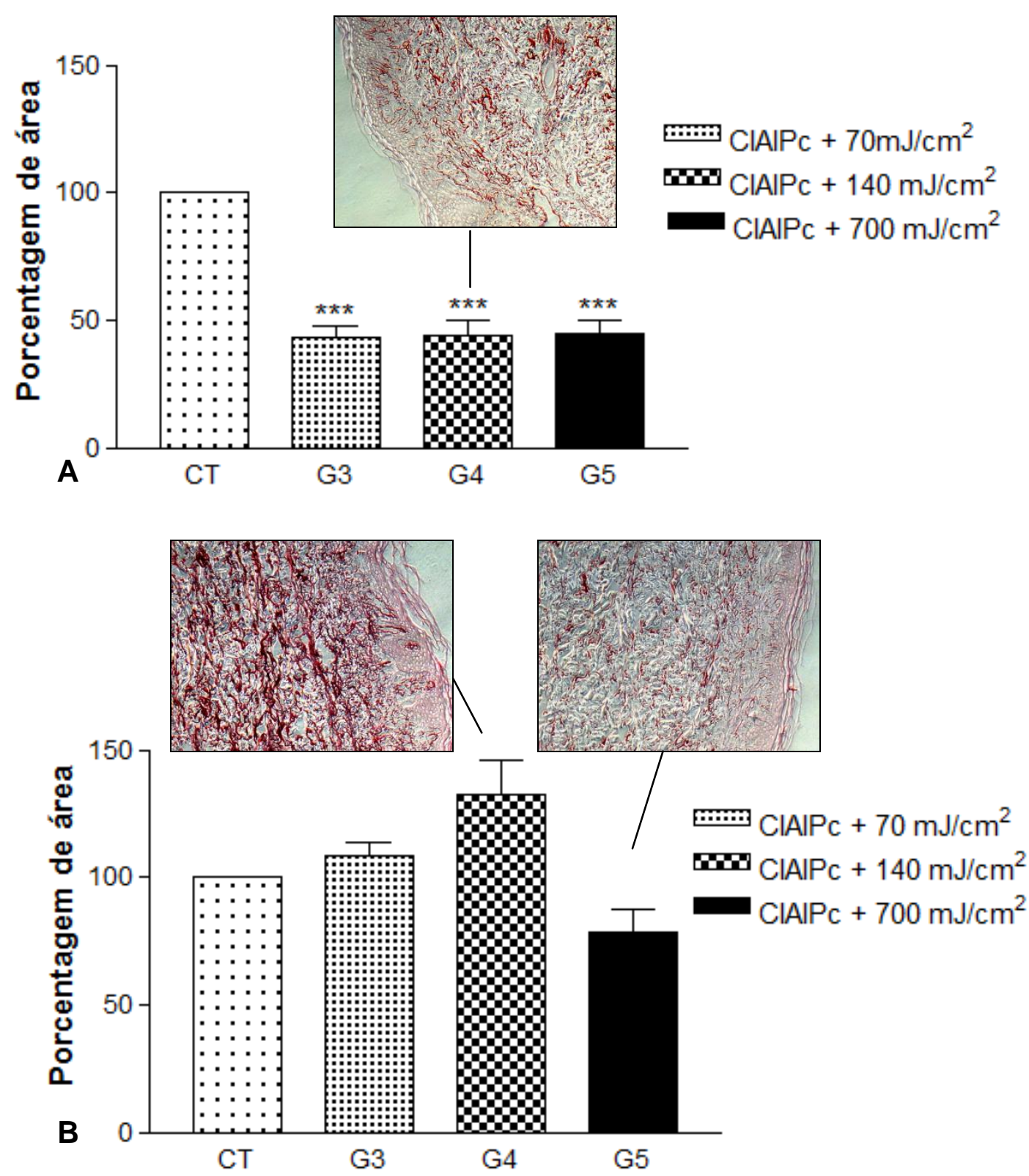

Figura 17. Comparação entre as porcentagens de área de elastina das biópsias de pele tratadas com a nanoemulsão contendo ClAlPc, irradiadas por laser de diodo $(670 \mathrm{~nm})$ em diferentes doses de 70, 140 e $700 \mathrm{~mJ} / \mathrm{cm}^{2}$ e incubadas por diferentes períodos: A) 7 dias; B) 14 dias. Os resultados são expressos como média \pm desvio padrão, sendo *** $(\mathrm{P}<0,001)$ estatisticamente significativos. 


\subsubsection{Análise para colágeno tipo I e tipo III}

As fibras colágenas clássicas são as fibras mais numerosas no tecido conjuntivo. No estado fresco estas fibras têm cor branca, conferindo esta cor aos tecidos nos quais predominam. Estas fibras são birrefringentes, pois são constituídas por moléculas alongadas arranjadas paralelamente umas às outras. Alguns corantes ácidos compostos por moléculas alongadas, como o Picrosirius Red, são capazes de se ligar paralelamente a moléculas de colágeno intensificando consideravelmente a sua birrefringência normal, produzindo uma cor amarela forte. Devido a esta propriedade, o Picrosirius Red é usado como um método específico para a detecção do colágeno, como foi o caso da metodologia escolhida para este trabalho (JUNQUEIRA e CARNEIRO, 2004). A coloração por Picrosirius Red é um método histoquímico. Sendo um ânion forte, é capaz de reagir e tingir o colágeno, por meio do seu grupamento sulfônico ácido com o grupamento básico presente na molécula do colágeno (SIMIONI, 2009). A Figura 18 apresenta a fórmula estrutural do Picrosirius Red, comercialmente conhecido como Direct Red 80 ou simplesmente Sirius Red.

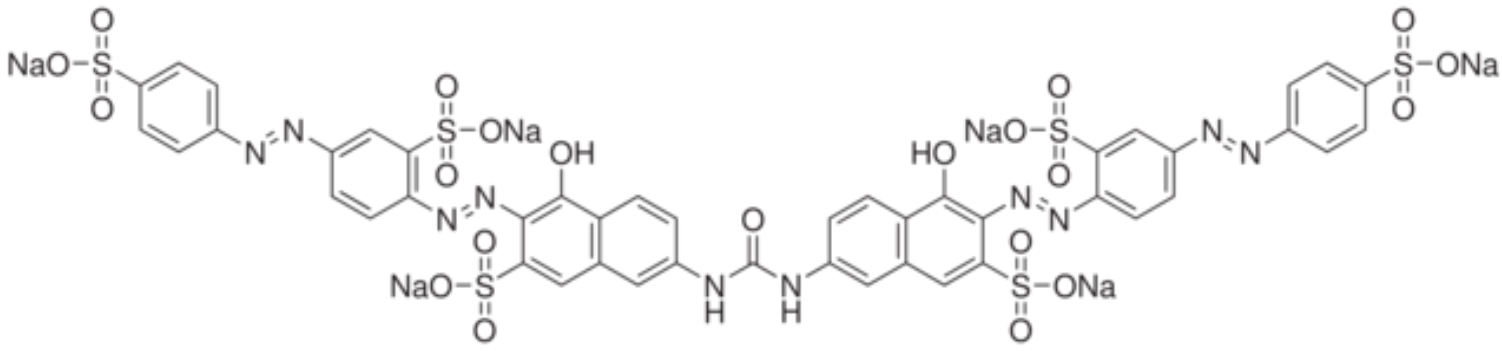

Figura 18. Molécula Direct Red 80 (Sirius Red, Picrosirius Red) Fonte: http://www.sigmaaldrich.com

A análise histomorfológica das biópsias coradas por Picrosirius Red mostrou as redes de colágeno presentes na derme, principalmente composta por colágeno do tipo I. O colágeno tipo I é o mais comum; aparece nos tendões, na cartilagem fibrosa, no tecido conjuntivo frouxo comum, no tecido conjuntivo denso (onde é predominante sobre os outros tipos), 
sempre formando fibras e feixes nos ossos, tendões e pele (SIMIONI, A. R., 2009). O colágeno tipo I é definido como colágeno antigo ou maduro, já o colágeno tipo III é definido como colágeno novo ou imaturo (DAMS et al., 2011).

Existem muitas classes estruturais de colágeno na matriz extracelular, incluindo fibrilas, redes e domínios de colágeno transmembrana. Fibrilas de colágeno tipo I em tendões são de aproximadamente $1 \mathrm{~cm}$ de comprimento e até $500 \mathrm{~nm}$ de diâmetro. A tripla hélice no colágeno do tipo I é menor do que $2 \mathrm{~nm}$ de diâmetro e $300 \mathrm{~nm}$ de comprimento. Uma característica das fibrilas de colágeno tipo I é a sua periodicidade na estrutura, sendo repetidas unidades ( $\mathrm{D}=67 \mathrm{~nm}$ ), como mostra a Figura 19 (SHOULDERS e RAINES, 2009).

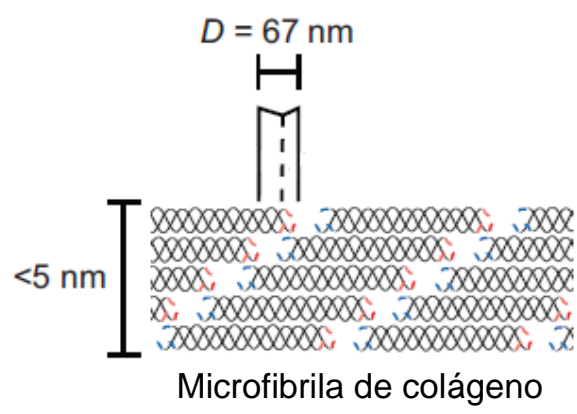

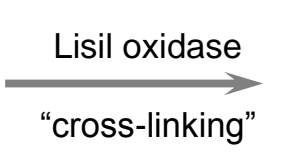

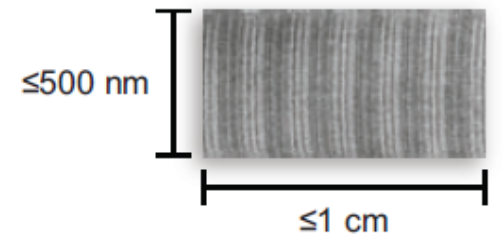

fibra de colágeno

Figura 19. Rota biosintética para formação de fibras de colágeno tipo I, principal componente estrutural da pele (adaptado de SHOULDERS e RAINES, 2009).

A Figura 20 ilustra as imagens obtidas por microscopia de campo claro (objetiva de 20x) das biópsias de pele coradas por Picrosirius Red. As imagens estão organizadas em dois grupos, um relacionado às amostras tratadas por 7 dias e outro às amostras tratadas por 14 dias. De acordo com a Figura 20 é possível verificar as divergências quanto à quantidade de fibras colágenas, bem como à intensidade dessas fibras, para cada amostra analisada. Alguns grupos foram destacados por apresentarem maior quantidade de colágeno, como é mostrado na Figura 20G, análise do grupo irradiado por $700 \mathrm{~mJ} / \mathrm{cm}^{2}$ de luz e tratado por 7 dias, e na Figura 20J, a qual aponta o grupo que recebeu tratamento com o fármaco fotossensibilizante e luz na dose de $140 \mathrm{~mJ} / \mathrm{cm}^{2}$ de luz e tratado por 14 dias. 


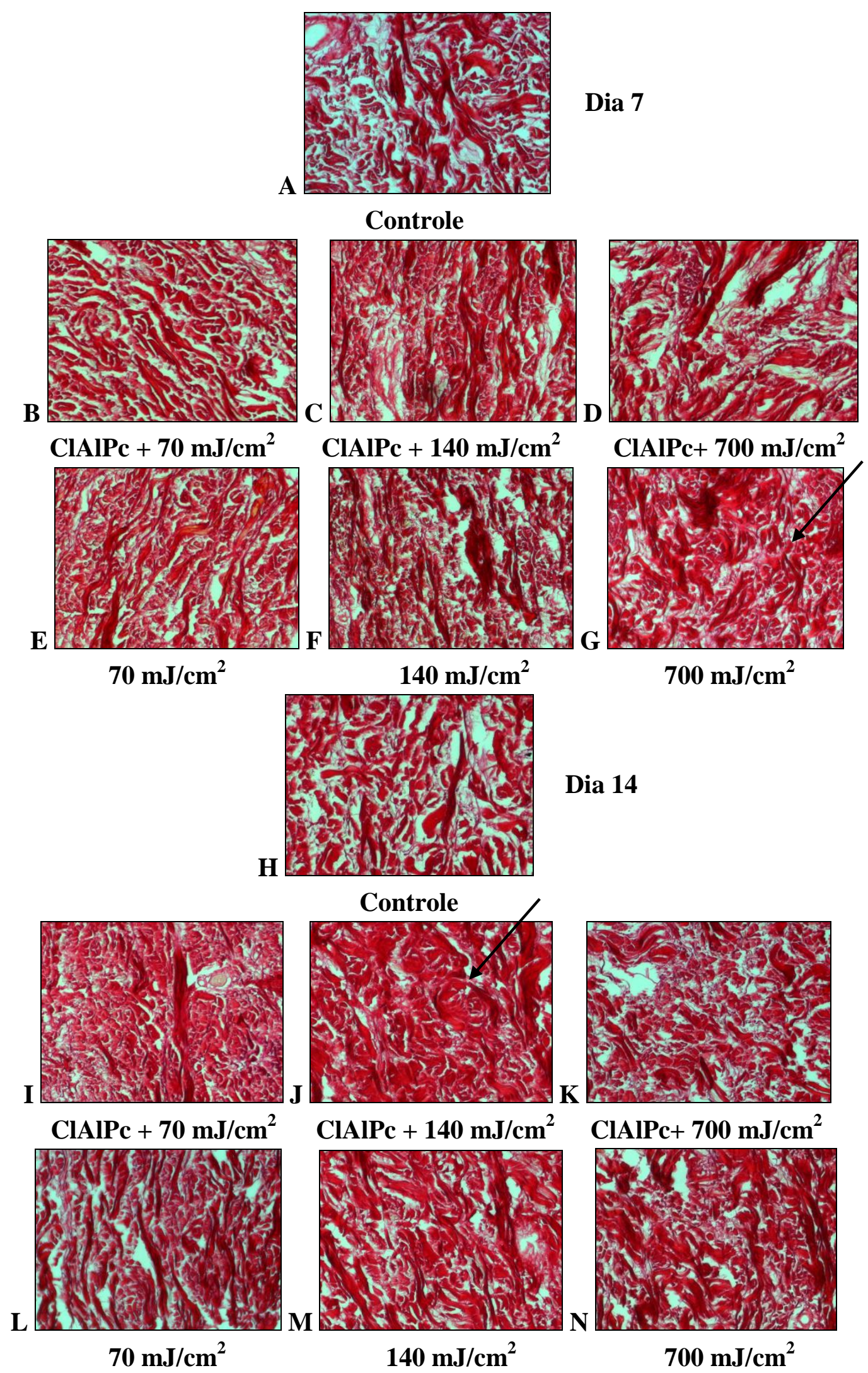

Figura 20. Análise histológica das biópsias de pele tratadas com ClAlPc, irradiadas por laser de diodo $(670 \mathrm{~nm})$ em diferentes doses, coradas por Picrosirius Red e visualizadas por microscopia de campo claro (objetiva de 20x). A primeira sessão apresenta as amostras tratadas por 7 dias e a segunda apresenta as amostras tratadas por 14 dias após a irradiação. 
Pode-se identificar na Figura 20 a densa rede de colágeno formada por fibras entrelaçadas, dispostas em feixes que não apresentam orientação fixa. Este tipo de tecido conjuntivo é classificado como não-modelado. As fibras muito finas de colágeno que caracterizam o tecido de granulação irão evoluir nesta fase para alcançar o diâmetro equivalente às fibras recuperadas, presentes em uma derme intacta, enquanto que os espaços inter-fibrilares irão diminuir. Este aumento do diâmetro das fibras está relacionado diretamente à resistência final dos tecidos neo formados frente às forças de tração. Apesar da pequena diferença na intensidade de coloração das lâminas, pode-se afirmar que a aplicação da TFD evita que a rede de colágeno sofra degradação, fator de suma importância para que ocorra o processo de cicatrização (SIMIONI, A. R., 2009).

Assim como na análise para elastina, inicialmente descrita no item 4.4.1, também foi realizada uma análise quantitativa das áreas correspondentes ao colágeno tipo I, como descrito no item 3.3.7. As Figuras 21 e 22 apresentam a análise quantitativa percentual das áreas onde estão presentes as redes de colágeno tipo I. A Figura 21 apresenta uma comparação entre as amostras que receberam tratamento somente com luz, em diferentes doses. 


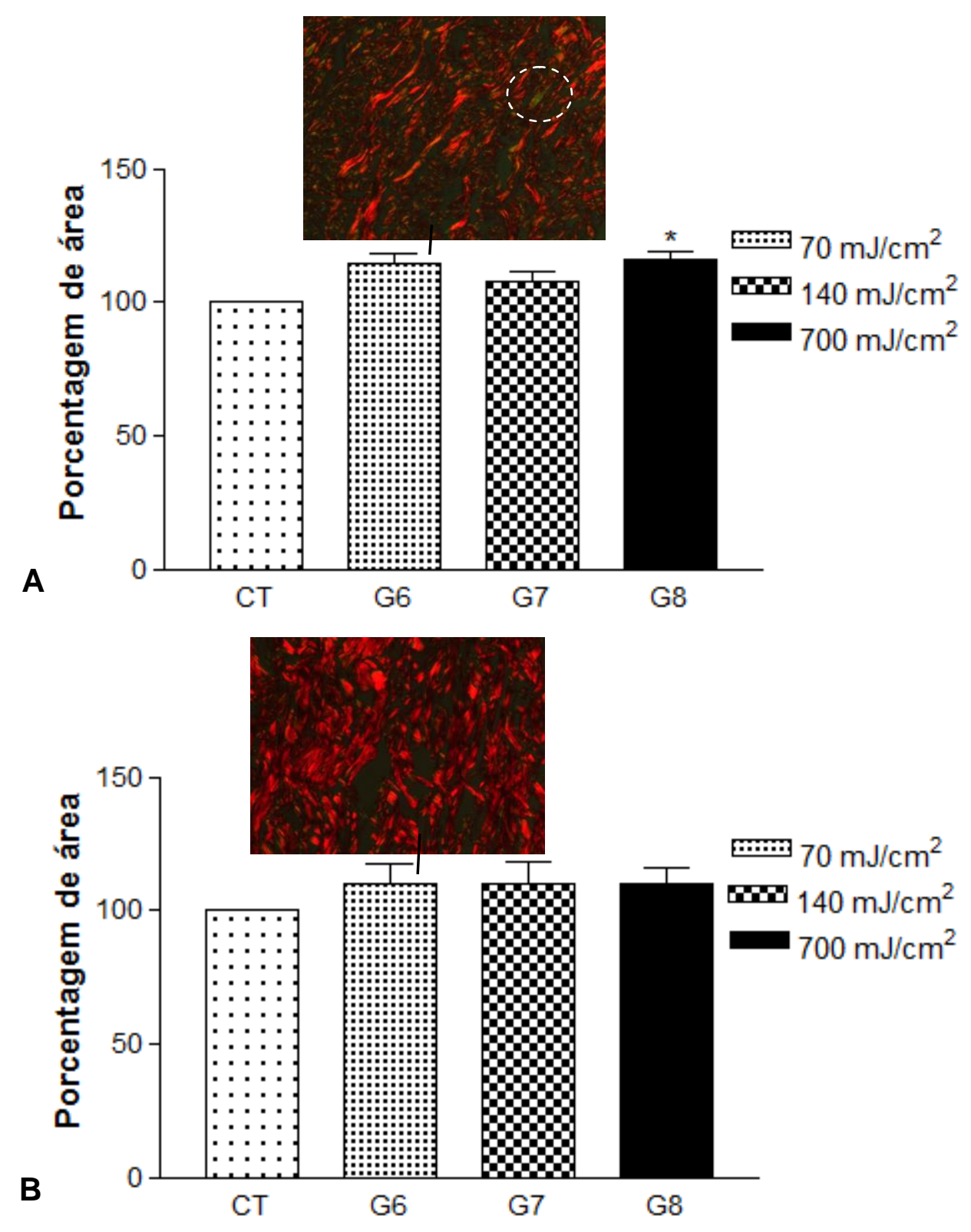

Figura 21. Comparação entre as porcentagens de área de colágeno tipo I das biópsias de pele irradiadas por laser de diodo $(670 \mathrm{~nm})$ em diferentes doses de 70,140 e $700 \mathrm{~mJ} / \mathrm{cm}^{2}$ e incubadas por diferentes períodos: A) 7 dias; B) 14 dias. Os resultados são expressos como média \pm desvio padrão, sendo * $(\mathrm{P}<0,05)$ estatisticamente significativo. 
A Figura 22 mostra uma comparação entre as amostras que receberam tratamento com o fármaco fotossensibilizante e luz, em diferentes doses.

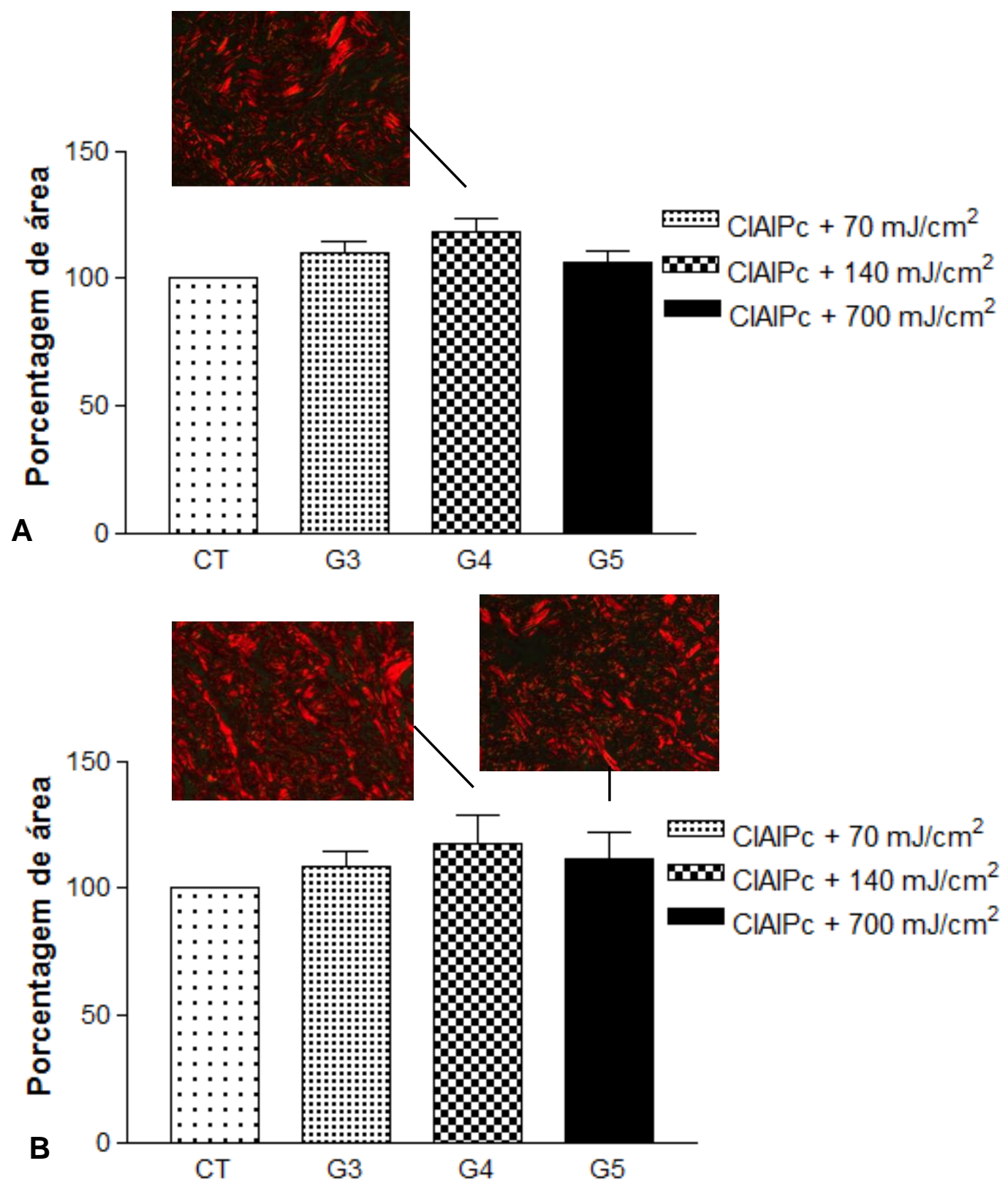

Figura 22. Comparação entre as porcentagens de área de colágeno tipo I das biópsias de pele tratadas com ClAlPc, irradiadas por laser de diodo $(670 \mathrm{~nm})$ em diferentes doses de 70, $140 \mathrm{e}$ $700 \mathrm{~mJ} / \mathrm{cm}^{2}$ e incubadas por diferentes períodos: A) 7 dias; B) 14 dias. Os resultados são expressos como média \pm desvio padrão. 
A diferença das porcentagens para cada grupo é mais evidente observando-se a Figura 23, a qual mostra uma comparação somente entre a diferença na porcentagem de área em relação ao controle para cada grupo analisado.
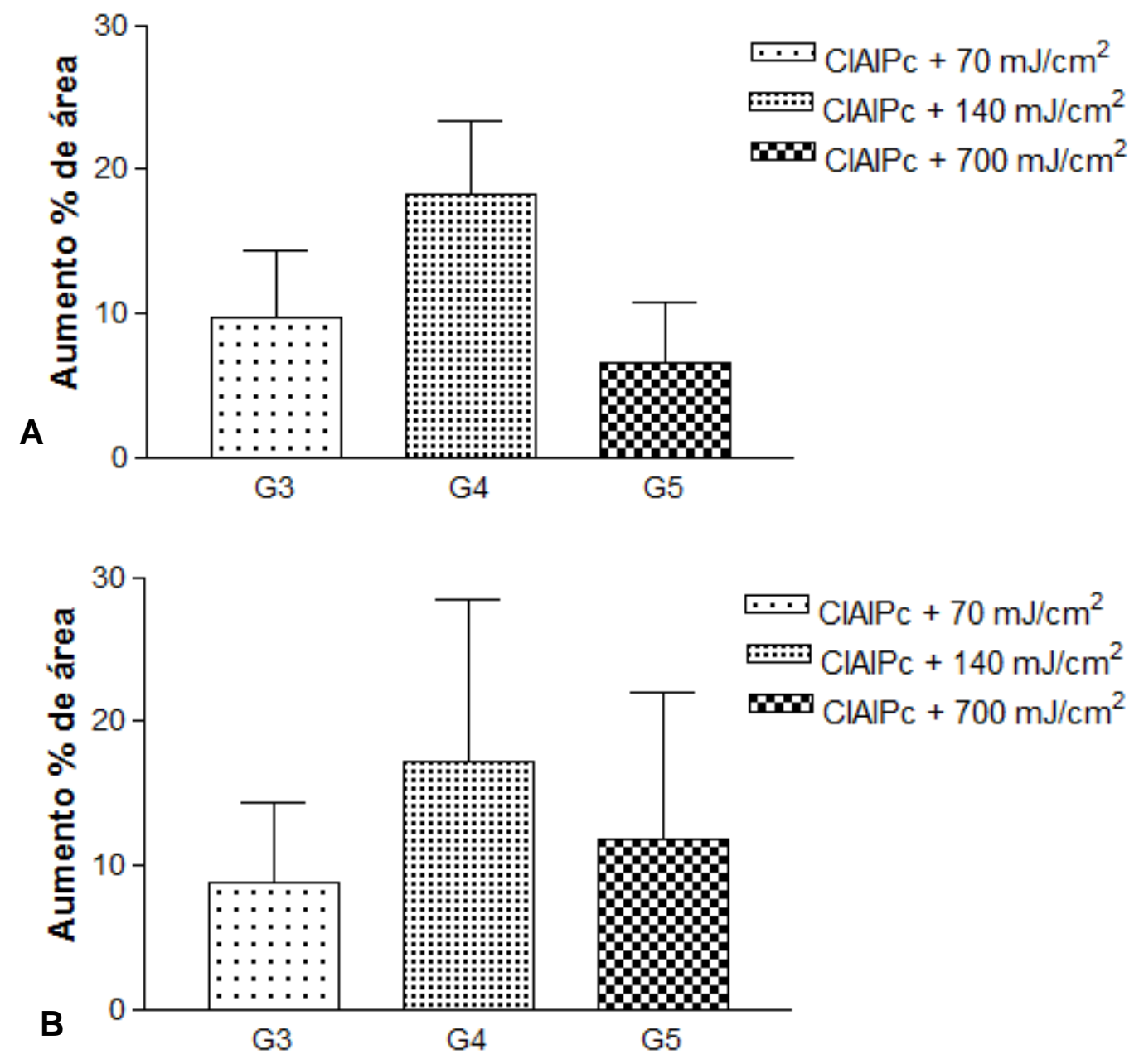

Figura 23. Comparação entre o aumento da porcentagem de área de colágeno tipo I em relação ao controle, sendo G3, G4 e G5 as amostras tratadas com a cloro alumínio ftalocianina e irradiadas com as respectivas doses 70,140 e $700 \mathrm{~mJ} / \mathrm{cm}^{2}$. A) 7 dias; B) 14 dias. Os resultados são expressos como média \pm desvio padrão.

De acordo com a análise quantitativa apresentada na Figura 21, dos grupos comparados o que apresentou maior efeito sobre o aumento da rede de colágeno, estatisticamente significativo, foi o grupo G8, que corresponde às amostras irradiadas por luz 
na dose de $700 \mathrm{~mJ} / \mathrm{cm}^{2}$ tratadas por 7 dias. Esse efeito pode ser melhor visualizado na Figura 18 G. Já para o período de 14 dias não se observou diferença significativa entre os grupos, porém houve um aumento em relação ao controle.

Constatou-se pela análise quantitativa apresentada nas Figuras 22 e 23 que não houve diferença significativa nos resultados das amostras referentes aos diferentes tempos de tratamento testados, porém em ambas as situações o grupo que se destacou foi o G4, correspondente às amostras tratadas com o fármaco fotossensibilizante e irradiadas com luz na dose de $140 \mathrm{~mJ} / \mathrm{cm}^{2}$. A diferença na quantidade de colágeno tipo I presente nas amostras deste grupo é evidente, como pode ser visto na Figura 20J.

Dessa forma, com relação à produção de colágeno tipo I, dentre os grupos analisados as combinações que exerceram maior estímulo foram a do grupo G8 (com 7 dias de tratamento) e G4 (com 14 dias de tratamento), que correspondem, respectivamente, à dose de $700 \mathrm{~mJ} / \mathrm{cm}^{2}$ e à combinação ClAlPc $+140 \mathrm{~mJ} / \mathrm{cm}^{2}$.

Além da microscopia de campo claro, as lâminas coradas por Picrosirius Red também foram visualizadas por luz polarizada, sendo possível observar não só o colágeno tipo I (refringência avermelhada), mas também o colágeno tipo III (reticulina), o qual se apresenta formado por fibras finas, pouco compactadas, corando do amarelo-esverdeado ao verde.

Quando raios de luz passam através de um filtro polarizador (como um filtro Polaroid), eles saem vibrando em uma só direção. Um segundo filtro colocado com seu eixo principal perpendicular ao primeiro bloqueará a passagem de luz. Se, porém, um tecido que tiver estruturas formadas por átomos e moléculas com um alto grau de orientação (como celulose, colágeno, cristais, microtúbulos e microfilamentos) for colocado entre os dois filtros, a estrutura molecular repetitiva e orientada modifica o plano de vibração da luz que emerge do primeiro filtro, fazendo com que essas estruturas apareçam luminosas contra um fundo 
escuro após passarem pelo segundo filtro. A capacidade que estruturas têm de girar o plano de vibração da luz polarizada é chamada de birrefringência (JUNQUEIRA e CARNEIRO, 2004).

As imagens obtidas utilizando-se luz polarizada apareceram nas Figuras 21 e 22, evidenciando a formação de colágeno tipo III em alguns grupos, principalmente os que receberam doses mais baixas de luz $\left(70 \mathrm{~mJ} / \mathrm{cm}^{2}\right.$; observar marcação na Figura 21). Dessa forma, embora houvesse a predominância de fibras vermelhas e mais longas de colágeno, observou-se também a produção de colágeno novo, acelerando assim a deposição de colágeno e auxiliando no processo regenerativo da pele.

Como o colágeno é a maior proteína estrutural e compõe de 70 a $80 \%$ do peso seco da pele, a modulação do metabolismo do colágeno na pele por irradiação terapêutica tem muita importância clínica. O colágeno, sintetizado por fibroblastos, compreende $80-85 \%$ de colágeno tipo I e 10-15\% de colágeno tipo III (RIEKKI et al., 2000).

Com base na análise histomorfológica das biópsias de pele, numa discussão geral sobre o tratamento mais efetivo para estimular tanto elastina quanto colágeno realizado neste trabalho, comparou-se todos os resultados apresentados. Este estudo mostrou que as biópsias analisadas após 14 dias do tratamento apresentaram uma maior intensidade, tanto nas redes de colágeno quanto nas de elastina, cujo efeito é mais pronunciado nas amostras que receberam tratamento combinado de fármaco fotossensibilizante e luz na dose de $140 \mathrm{~mJ} / \mathrm{cm}^{2}$. Após a aplicação de doses maiores de irradiação $\left(700 \mathrm{~mJ} / \mathrm{cm}^{2}\right)$ observou-se uma degradação das fibras colágenas e de elastina comparada com a dose intermediária.

Portanto, o modelo de cultivo de biópsias de explants em gel de colágeno permitiu avaliar o efeito de um estímulo externo, no caso a TFD, diretamente sobre a formação e degradação da rede de elastina e de colágeno da pele por análise histológica clássica, possibilitando analisar o comportamento de componentes celulares importantes, antes e 
depois do tratamento com luz, auxiliando no processo cicatricial de feridas e outras doenças cutâneas.

Até o momento existem poucos trabalhos na literatura relatando a aplicação da TFD na cicatrização de feridas. Os poucos existentes relatam a utilização de fármacos fotossensibilizantes de primeira geração, como é o caso do ALA e da hematoporfirina, utilizando ratos como modelos animais nos estudos in vivo (JAYASREE et al., 2011; PEPLOW , CHUNG e BAXTER, 2012). Os estudos em humanos já relatados consistem da aplicação da TFD no tratamento da acne, manchas na pele e no fotorejuvenescimento (BISSONNETTE, 2011, SZEIMIES et al., 2012). Dessa forma, é difícil comparar os resultados obtidos neste trabalho com resultados já existentes na literatura, por consistir de um fármaco de segunda geração, no caso a cloro alumínio ftalocianina, que possui propriedades fotoquímicas e fotofísicas mais favoráveis para a utilização da TFD e também por utilizar uma matriz complexa, como as biópsias de explants de pele. Além disso, as diferentes fontes de luz possíveis de serem utilizadas na TFD fazem com que uma ampla variedade de parâmetros como irradiância, comprimento de onda e doses de luz sejam estabelecidos de modo a maximizar os efeitos do estímulo luminoso.

No entanto, alguns resultados envolvendo o tratamento de feridas em ratos utilizando ALA como o agente fotossensibilizante e laser de He-Ne mostraram que o completo fechamento das feridas provocadas nos ratos ocorreu após 14 dias do tratamento, podendo variar até 19 dias (SZEIMIES et al., 2012). Dessa forma, os resultados apresentados neste trabalho foram condizentes com o esperado, mostrando que 14 dias após o tratamento das biópsias de explants de pele com a nanoemulsão contendo ClAlPc e irradiação com laser de diodo foram adequados para evidenciar a produção de colágeno e elastina, caracterizando o processo de remodelação que ocorre durante o processo cicatricial. 


\subsection{Avaliação da expressão das enzimas MMP-2 e MMP-9 por zimografia}

A expressão das proteínas MMP-2 e MMP-9 foi detectada por zimografia de gelatina. Uma vez que gelatinases são proteases secretadas (DAMODHARAN , GANESAN e RADHAKRISHNAN, 2011), o sobrenadante do meio de cultura das biópsias de pele foi recolhido para a análise. Foram analisados os meios de cultura recolhidos após 7 e 14 dias do tratamento das biópsias de explants de pele utilizando a nanoemulsão contendo o fármaco fotossensibilizante, irradiadas por diferentes doses de luz e cultivadas em gel de colágeno. São apresentados três conjuntos de dados (Figuras 24, 25 e 26), respectivos às amostras que receberam diferentes tempos de tratamento, que representam os ensaios realizados em triplicata para cada condição estabelecida no experimento.

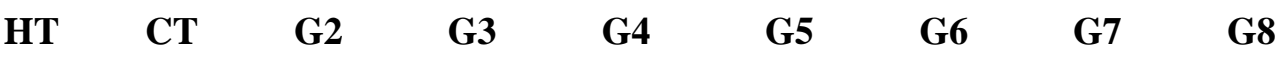

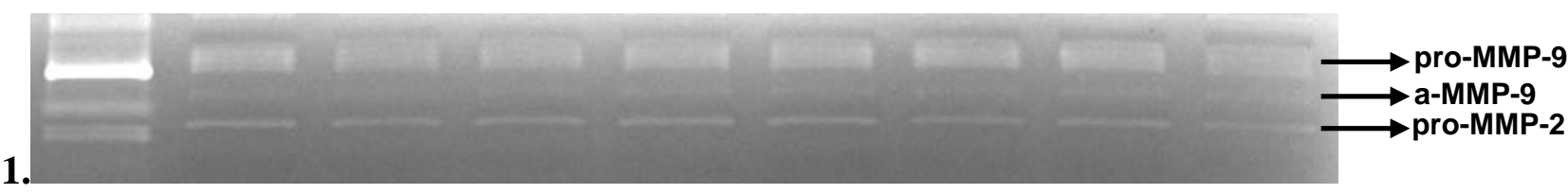
HT CT
G2
G3
G4
G5
G6
G7
G8

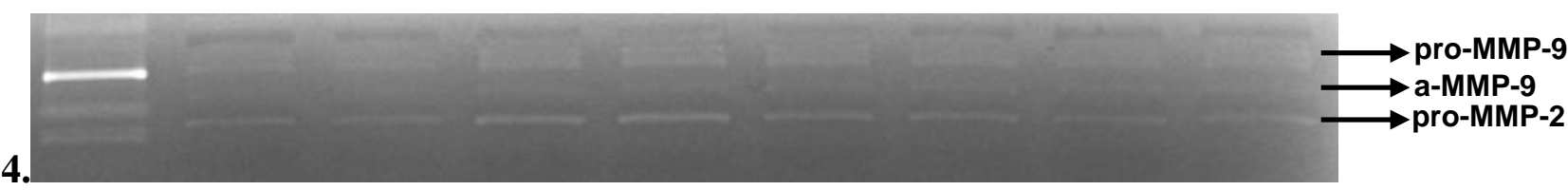

Figura 24. Conjunto dos géis 1 e 4 de zimografia, respectivos às amostras tratadas por 7 e 14 dias. 


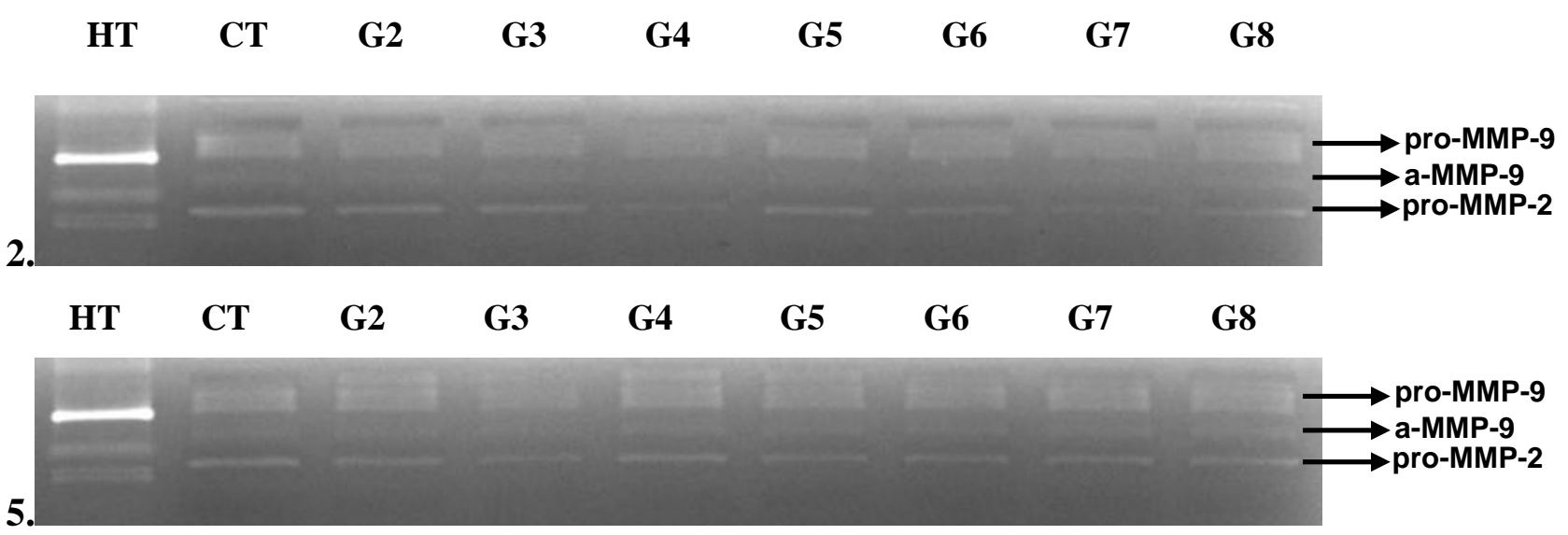

Figura 25. Conjunto dos géis 2 e 5 de zimografia, respectivos às amostras tratadas por 7 e 14 dias.

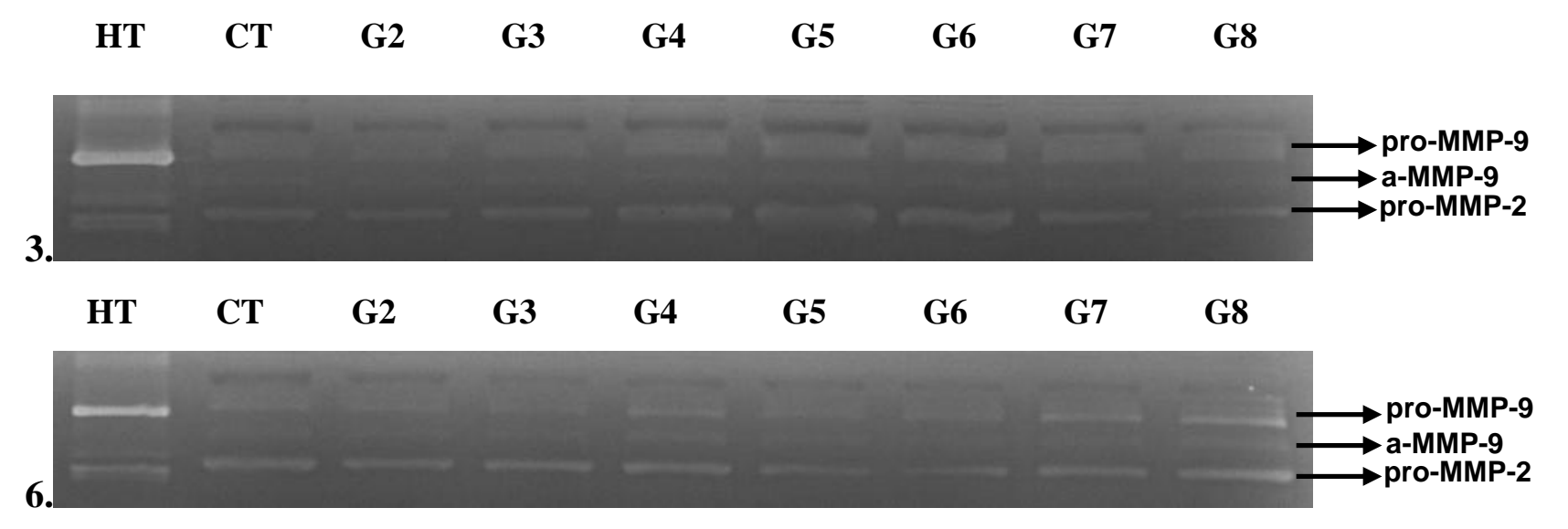

Figura 26. Conjunto dos géis 3 e 6 de zimografia, respectivos às amostras tratadas por 7 e 14 dias.

De acordo com os resultados apresentados nas Figuras 24, 25 e 26, não se observou diferença entre os géis que representam o mesmo período de tratamento, o que mostra que houve reprodutibilidade tanto no preparo das amostras para os ensaios de zimografia quanto na parte experimental envolvendo as biópsias de pele.

Comparando-se a intensidade das bandas referentes às amostras com aquelas referentes ao meio isolado da linhagem HT-1080 (linhagem celular utilizada como padrão para expressão de MMP-2 e MMP-9) (CHAKRABARTI et al., 2006), foi observado em todos os géis a presença das bandas pertencentes à pró-gelatinase A - MMP-2-p e à forma pró- 
gelatinase B - MMP-9-p, além de uma banda fraca atribuída à forma ativa da gelatinase B MMP-9- $a$. Contudo, comparando-se os géis realizados em dias diferentes de tratamento, notou-se uma maior intensidade das bandas nos grupos cujas amostras foram recolhidas no $14^{\circ}$ dia de tratamento em relação àquelas recolhidas no $7^{\circ}$ dia de tratamento. Estas observações condizem com os resultados da análise histológica (item 4.4), o qual demonstrou um aumento da produção de colágeno e elastina nas biópsias de pele, visto somente após 14 dias, como é mostrado nas Figuras 16, 17 e 20.

As bandas referentes aos diferentes grupos em cada gel (Figuras 24, 25 e 26) foram quantificadas conforme descrito no item 3.3.9. Os resultados são apresentados em porcentagem de expressão de MMP-9 e MMP-2 em relação ao controle e aparecem nas Figuras 27 e 28 . Este tratamento dos dados permite identificar as bandas e quantificar a intensidade de cor de cada uma em relação à banda referente ao controle (amostra sem tratamento), fornecendo os resultados em porcentagem.

Quanto à expressão das metaloproteases do tipo MMP-9, para o mesmo período de análise, foi indicada uma atividade gelatinolítica característica com uma banda atribuída à forma pró-gelatinase B e outra banda, de menor intensidade, atribuída à forma ativa da gelatinase B. A quantificação dessas bandas, Figura 27, mostrou que durante o período inicial não houve diferença significativa, quanto à expressão de MMP-9, entre o tratamento com fármaco fotossensibilizante e irradiação com diferentes doses de luz e o tratamento aplicando somente luz, nas mesmas doses. Por outro lado, para o período de 14 dias essa diferença foi mais evidente, sendo que o grupo que foi tratado com a nanoemulsão de ClAlPc e irradiado com luz na dose de $140 \mathrm{~mJ} / \mathrm{cm}^{2}$ (G4) apresentou resultados que indicaram uma maior expressão de MMP-9 em relação ao controle. Esta análise se mostrou condizente com a análise histológica, a qual indicou essa condição de tratamento a mais apropriada, uma vez que estimulou tanto a produção de elastina quanto a de colágeno (Figuras 16, 17 e 20). 

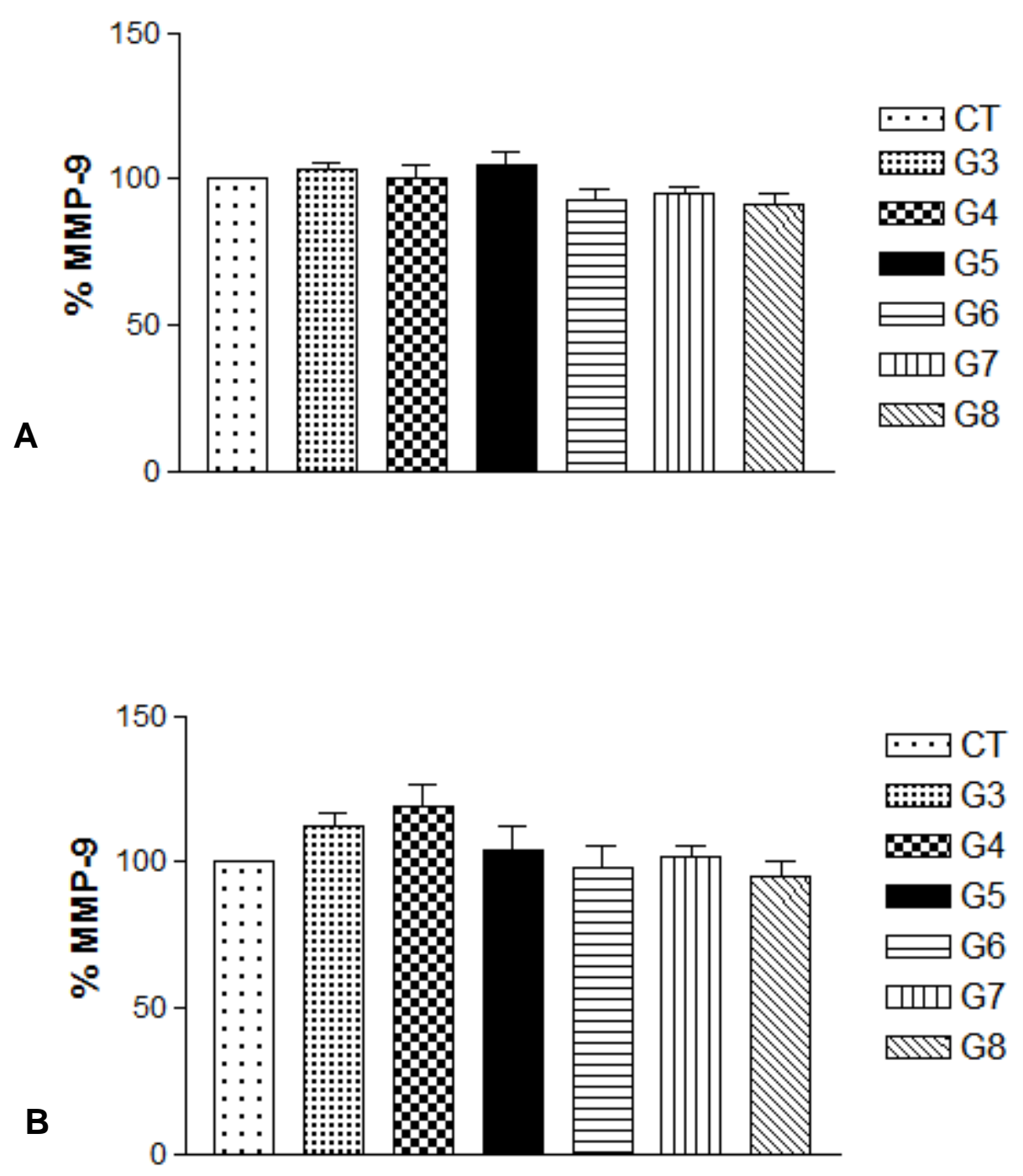

Figura 27. Atividade gelatinolítica detectada por zimografia dos meios de cultura coletados após experimento com biópsias de explants de pele cultivadas em gel de colágeno, expressa em porcentagem de expressão de MMP-9 em relação à amostra do controle. A) 7 dias; B) 14 dias. Os resultados são expressos como média \pm desvio padrão.

A gelatinase B (MMP-9) é uma típica MMP, importante para a migração de diferentes tipos celulares, como leucócitos e células tumorais, devido à sua habilidade de degradar membranas basais e componentes da matriz extracelular, como colágeno e elastina. A gelatinase B promove a migração de novos leucócitos formados a partir da medula óssea até 
os vasos sanguíneos, e então dos vasos sanguíneos até os locais de infecção nos tecidos (VAN DEN STEEN et al., 2001).

A expressão de MMP-9 é normalmente constante durante toda a fase de remodelagem do tecido. Além disso, a expressão de MMP-9 está diretamente relacionada ao processo de migração celular durante o processo de morfogênese e organogênese (LELONGT et al., 1997), remodelagem da matriz extracelular (EL FAHIME et al., 2000), e cicatrização de feridas (CLARK, 1993). Igualmente, a MMP-9 tem sido considerada uma metaloprotease eficiente durante o processo de criação e desenvolvimento de rede fibrilar, associada à produção da rede de elastina particularmente pela presença de fibrilina do tipo I (COULOMB et al., 1983).

Quanto à expressão de MMP-2, foi evidenciada na análise dos géis de zimografia uma maior expressão das metaloproteases do tipo MMP-2 do que do tipo MMP-9, visto pela maior intensidade daquelas bandas em relação a estas. Foi observada somente a banda referente à forma pró da gelatinase A, tornando-se evidente a ausência da sua forma ativa. Por meio da quantificação dessas bandas (Figura 28), observou-se que mesmo no período inicial de 7 dias foi possível evidenciar alguns grupos, como é o caso das amostras tratadas com o fármaco fotossensibilizante e luz na dose de $140 \mathrm{~mJ} / \mathrm{cm}^{2}$ (G4), além do grupo que recebeu tratamento somente com luz na dose de $700 \mathrm{~mJ} / \mathrm{cm}^{2}$ (G8), destacando-se o primeiro. Entretanto, para as amostras analisadas mais tardiamente $\left(14^{\circ}\right.$ dia) não foi observado um aumento evidente na expressão de MMP-2 em relação às amostras analisadas após 7 dias, sendo o G8 o grupo que apresentou melhores resultados. 

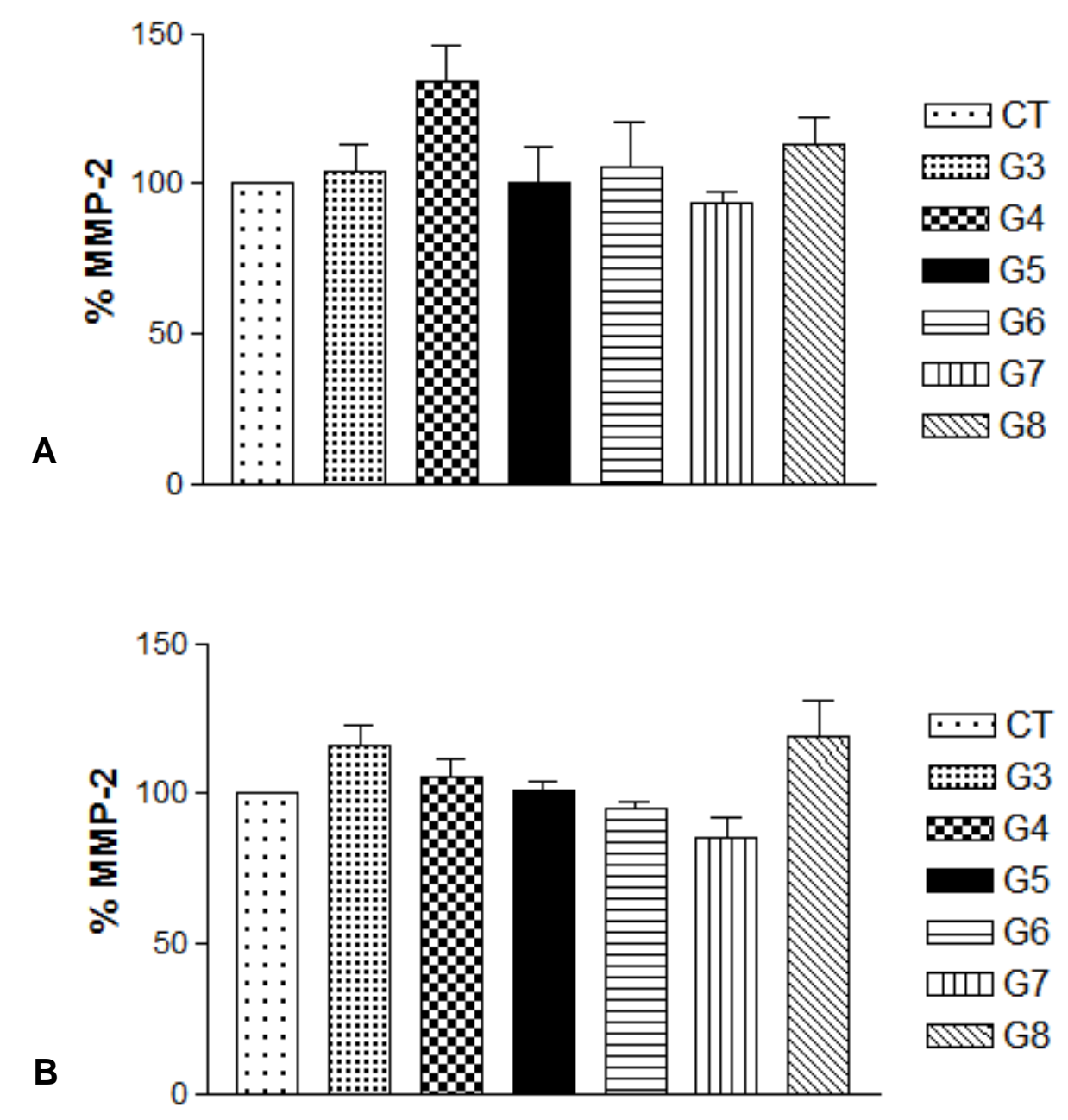

Figura 28. Atividade gelatinolítica detectada por zimografia dos meios de cultura coletados após experimento com biópsias de explants de pele cultivadas em gel de colágeno, expressa em porcentagem de expressão de MMP-2 em relação à amostra do controle. A) 7 dias; B) 14 dias. Os resultados são a média \pm desvio padrão.

De forma análoga ao descrito para a MMP-9, a expressão da MMP-2 na matriz extracelular e no meio de cultura é observada após a fase de remodelagem da látice de colágeno. Trabalhos prévios demonstraram que os fibroblastos dermais apresentam um crescimento da expressão das formas MMP-2 entre o $1^{\circ}$ e $21^{\circ}$ dia de desenvolvimento (CHAUSSAIN-MILLER et al., 2002).

Uma vez que as enzimas que degradam a matriz extracelular são sintetizadas por células, existe um controle importante quanto à produção dessas enzimas, que é a latência. As 
enzimas são sintetizadas como pró-enzimas, que são inativas até serem ativadas por (auto)proteólise. Esse tipo de mecanismo dá início a uma cascata de eventos na qual cada enzima é ativada por outra que a precede e ao mesmo tempo ativa a enzima que a sucede. Assim, a conversão da pró-gelatinase B para a sua forma ativa é catalisada pela MMP-3, enzima que a precede, ou pela gelatinase A (MMP-2) (VAN DEN STEEN et al., 2001), como é mostrado na Figura 29.
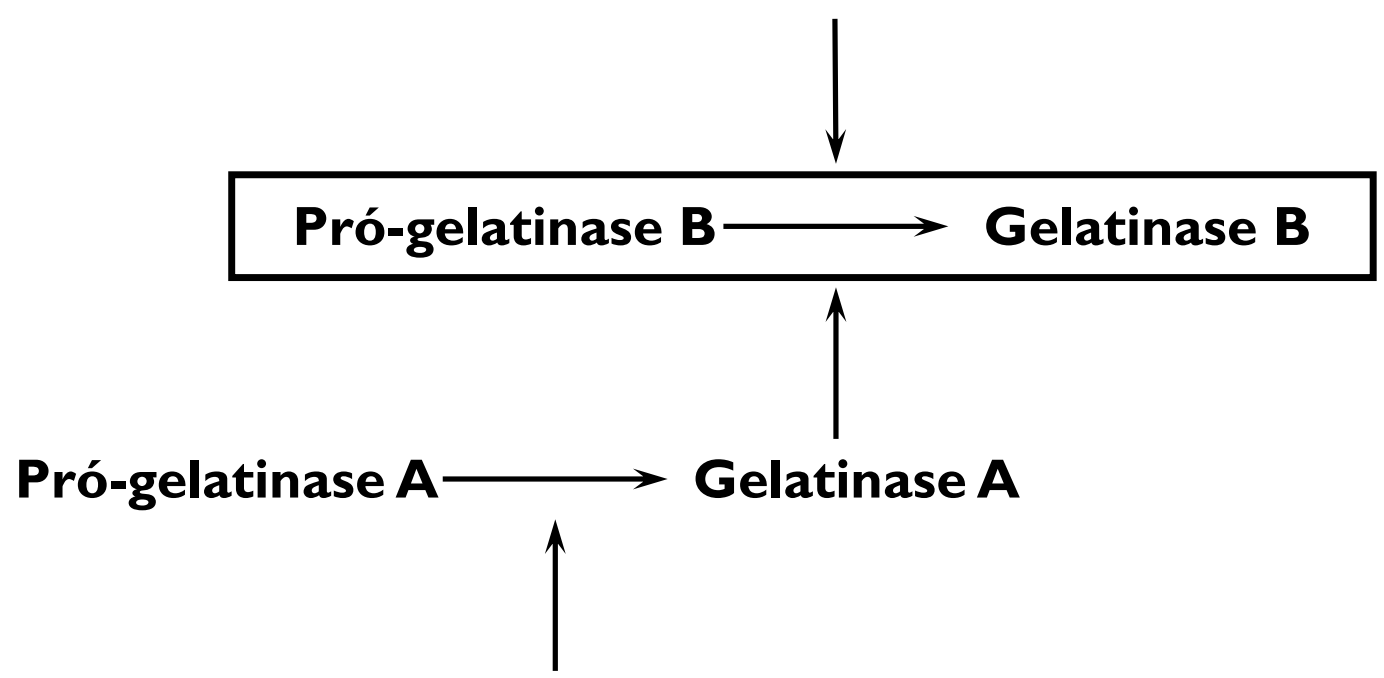

Figura 29. Parte da cascata proteolítica mostrando a ativação da pró-gelatinase $B$ em gelatinase B (Adaptado de VAN DEN STEEN et al., 2001).

A ativação das MMPs, passando da sua forma latente para a forma ativa, é alcançada pela saída do grupamento amino terminal dos resíduos de cisteína, cujo processo impõe latência por um mecanismo conhecido como mudança de cisteína. Assim como a ativação, a glicosilação é uma importante modificação pós-translacional das enzimas na cascata proteolítica. As gelatinases também possuem um domínio composto por três unidades repetidas de fibronectina, inserido entre o sítio ativo e o domínio com ligação de zinco, como mostrado nas Figuras 30 e 31. Cada repetição de fibronectina contém uma parte hidrofófica para ligação com gelatina, a qual constitui um sítio que permite ligação com substratos colagenosos (VAN DEN STEEN et al., 2001). 


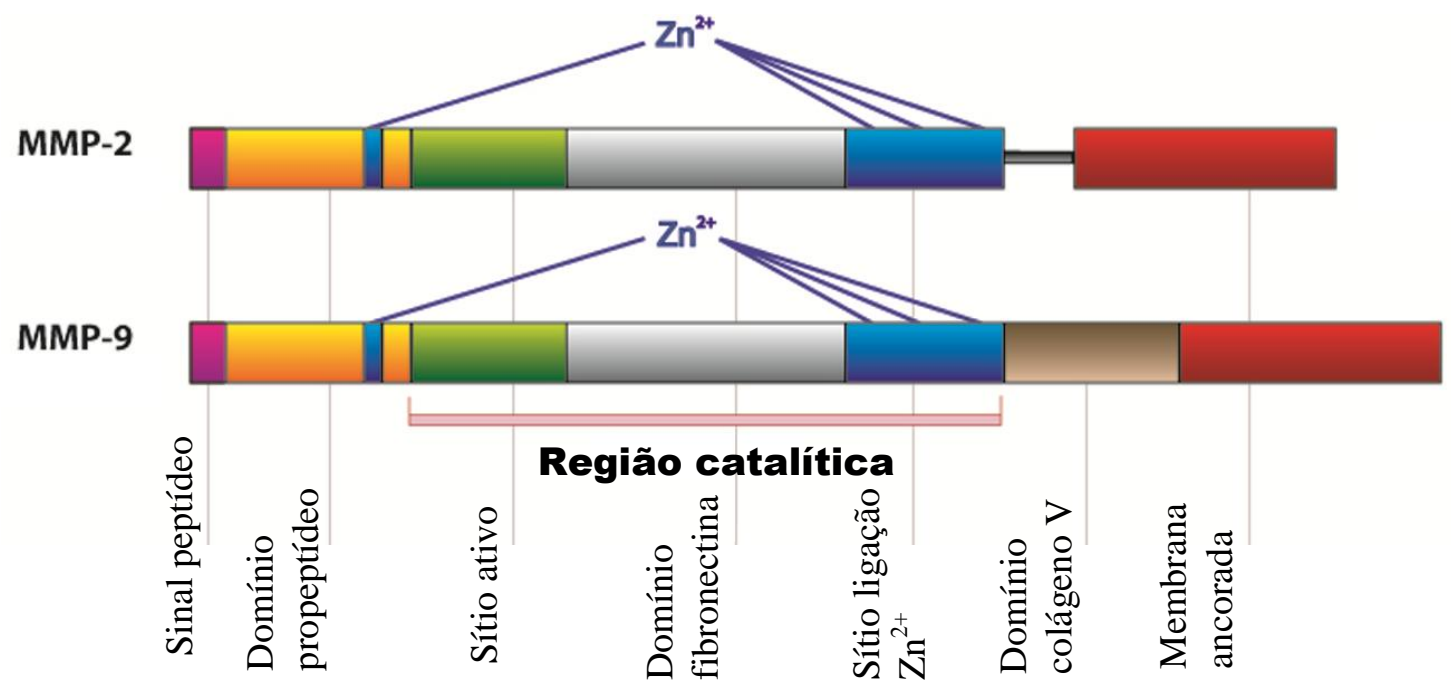

Figura 30. Estrutura esquemática da MMP-2 e da MMP-9, evidenciando os principais domínios e a região catalítica. Fonte: http://arthritis-research.com/content/10/6/229/figure/F1

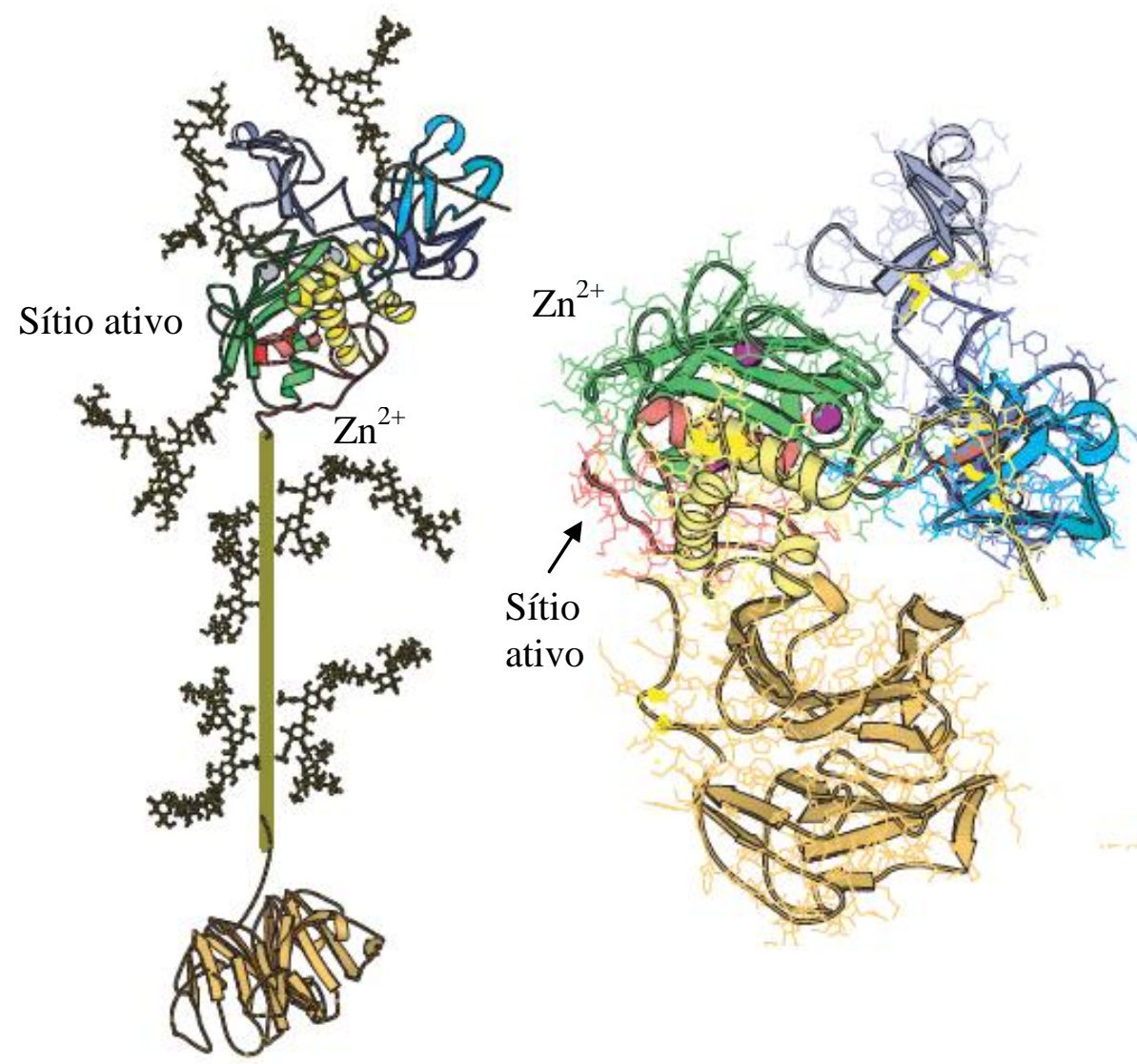

Figura 31. Gelatinases A e B (MMP-2 e MMP-9, respectivamente), mostrando alguns dos seus domínios (Adaptado de VAN DEN STEEN et al., 2001) 
Nelson e Melendez (NELSON e MELENDEZ, 2004) demonstraram que a expressão e ativação das MMPs são reguladas via processos oxidativos a partir de reações do tipo redox envolvendo espécies reativas de oxigênio (EROs) em organismos aeróbicos via mecanismos mitocondriais e de modulação celular. A radiação monocromática e os mecanismos fotodinâmicos alteram a concentração intra/intercelular de EROs, afetando o metabolismo eletrofisiológico mitocondrial, o que pode levar a aceleração da transcrição e expressão de MMPs além de outras biomoléculas presentes na matriz extracelular. O processo de peroxidação também atua diretamente na ativação do sítio Zn/cisteína, presente nas moléculas de MMPs, favorecendo a clivagem autocatalítca para liberação da forma ativa das metaloproteases (PRIMO, F. L., 2009).

Um estudo (SZEIMIES et al., 2012) demonstrou que espécies reativas de oxigênio geradas após a irradiação por luz UV dão início ao aumento da transcrição de metaloproteinases da matriz por um complexo mecanismo de sinalização, diminuindo a expressão dos genes procolágeno-I e procolágeno-III e culminando na redução da geração da matriz dermal.

Alguns processos fisiológicos, como o envelhecimento e o processo cicatricial, podem ser avaliados relacionando a síntese de colágeno com os níveis de expressão de MMPs. A deficiência de colágeno devida ao envelhecimento natural pode derivar da sua síntese reduzida com aumento da degradação e concomitante elevação da expressão de MMP. A irradiação ultravioleta induz a síntese de MMP na pele humana in vivo, e a destruição de colágeno mediada por MMP leva em conta, em grande parte, o dano provocado no tecido conectivo que ocorre no fotoenvelhecimento (SHIN et al., 2005). Isso sugere que não somente a síntese de proteína na matriz extracelular, mas também a degradação da MEC é elevada nas peles irradiadas (RIEKKI et al., 2000). 


\section{Conclusões}

A nanoemulsão de cloro alumínio ftalocianina apresentou características adequadas para a sua utilização nos estudos com pele humana, tais como boa estabilidade termodinâmica, tamanho médio de gotículas nanométrico e homogeneidade, além de possuir parâmetros importantes já conhecidos, como baixa agregação das moléculas em ambiente fisiológico e absorção máxima em 670 nm, a qual coincide com a região espectral da "janela óptica" do tecido. Partindo deste ponto, foi estipulado um roteiro experimental permitindo avaliar três diferentes doses de luz, sendo elas 70, 140 e $700 \mathrm{~mJ} / \mathrm{cm}^{2}$, e suas ações combinadas com o fármaco fotossensibilizante em biópsias de explants de pele após diferentes tempos de tratamento.

As análises histomorfológicas das biópsias coradas por Orceína e Picrosirius Red mostraram a forma do tecido epitelial, delimitando estruturas como a derme e a epiderme, sendo possível avaliar os principais componentes da matriz extracelular, como colágeno e elastina. A quantificação desses componentes nas biópsias de pele submetidas ao tratamento por diferentes doses de luz mostrou que a dose intermediária testada $\left(140 \mathrm{~mJ} / \mathrm{cm}^{2}\right)$ foi a mais apropriada, após 14 dias de tratamento, combinada com a ação do fármaco fotossensibilizante ClAlPc, provocando um efeito bioestimulador. Doses mais elevadas de luz provocaram a degradação das redes de colágeno e elastina, cujo efeito era esperado, considerando que altas concentrações de EROs provocam um efeito inibitório na síntese de fibroblastos dermais, reduzindo assim a síntese de colágeno e elastina.

Os estudos de zimografia mostraram a atividade gelatinolítica das enzimas Gelatinase A (MMP-2) e Gelatinase B (MMP-9), principais metaloproteases participantes do processo cicatricial de feridas. Os níveis de expressão de MMP-2 e MMP-9 condizem com os resultados obtidos após a análise histomorfológica, apontando um maior nível de expressão 
para o grupo que recebeu o tratamento combinado com o fármaco fotossensibilizante e luz na dose de $140 \mathrm{~mJ} / \mathrm{cm}^{2}$, após 14 dias de tratamento. Com estes estudos, pôde-se demonstrar que a expressão das MMPs foi afetada pela ação do fármaco fotossensibilizante e pela irradiação luminosa visível na faixa de energia utilizada. Assim, o modelo de biópsias de explants de pele não só pode ser usado como uma ferramenta útil para investigar mais profundamente os mecanismos de expressão e inibição durante as diferentes fases do processo de cicatrização, como também indica que a proposta de utilizar os princípios usualmente descritos para a Terapia Fotodinâmica é perfeitamente factível e pode, dentro das condições ideais, auxiliar no processo de cicatrização de feridas e outras doenças cutâneas. 


\section{Referências Bibliográficas}

AGOSTINIS, P.; BERG, K.; CENGEL, K. A.; FOSTER, T. H.; GIROTTI, A. W.; GOLLNICK, S. O.; HAHN, S. M.; HAMBLIN, M. R.; JUZENIENE, A.; KESSEL, D.; KORBELIK, M.; MOAN, J.; MROZ, P.; NOWIS, D.; PIETTE, J.; WILSON, B. C.; GOLAB, J. Photodynamic Therapy of Cancer: An Update, Ca-A Cancer Journal for Clinicians, v. 61, p. 250-281, 2011.

AGREN, M. S. Gelatinase Activity During Wound-Healing, British Journal of Dermatology, v. 131, p. 634-640, 1994.

AHMAD, S.; BEARELLY, S.; STINNETT, S. S.; COONEY, M. J.; FEKRAT, S. Photodynamic therapy for predominantly hemorrhagic lesions in neovascular age-related macular degeneration, American Journal of Ophthalmology, v. 145, p. 1052-1057, 2008.

ALEXANDRATOU, E.; YOVA, D.; HANDRIS, P.; KLETSAS, D.; LOUKAS, S. Human fibroblast alterations induced by low power laser irradiation at the single cell level using confocal microscopy, Photochemical \& Photobiological Sciences, v. 1, p. 547-552, 2002.

AUKHIL, I. Biology of wound healing, Periodontology 2000, v. 22, p. 44-50, 2000.

BALBINO, C. A.; PEREIRA, L. M.; CURI, R. Mecanismos envolvidos na cicatrização: uma revisão, Revista Brasileira de Ciências Farmacêuticas, Revista Brasileira de Ciências Farmacêuticas, v. 41, p. 27-51, 2005.

BARBUGLI, P. A. Estudo dos efeitos da terapia fotodinâmica na progressão tumoral e em modelos celulares tridimensionais. Tese de Doutorado - Faculdade de Ciências Farmacêuticas de Ribeirão Preto - USP, Ribeirão Preto - SP, 2010.

BECHET, D.; COULEAUD, P.; FROCHOT, C.; VIRIOT, M. L.; GUILLEMIN, F.; BARBERI-HEYOB, M. Nanoparticles as vehicles for delivery of photodynamic therapy agents, Trends in Biotechnology, v. 26, p. 612-621, 2008.

BISSONNETTE, R. Treatment of acne with photodynamic therapy, Giornale Italiano di Dermatologia e Venereologia, v. 146, p. 445-456, 2011.

BODE, W.; MASKOS, K. Structural basis of the matrix metalloproteinases and their physiological inhibitors, the tissue inhibitors of metalloproteinases, Biological Chemistry, v. 384, p. 863-872, 2003.

BULLEN, E. C.; LONGAKER, M. T.; UPDIKE, D. L.; BENTON, R.; LADIN, D.; HOU, Z. Z.; HOWARD, E. W. Tissue Inhibitor of Metalloproteinases-1 Is Decreases and Activated Gelatinases Are Increased in Chronic Wounds, Journal of Investigative Dermatology, v. 104, p. 236-240, 1995.

CASTANO, A. P.; DEMIDOVA, T. M.; HAMBLIN, M. R. Mechanisms in photodynamic therapy: part one - photosensitizers, photochemistry and cellular localization, Photodiagnosis and Photodynamic Therapy, v. 1, p. 279-293, 2004. 
CHAKRABARTI, J.; MITRA, A.; BANERJI, A.; CHATTERJEE, A. Culture of human fibrosarcoma HT-1080 cells in presence of fibronectin activates MMP-2, Journal of Environmental Pathology Toxicology and Oncology, v. 25, p. 667-677, 2006.

CHATTERJEE, D. K.; FONG, L. S.; ZHANG, Y. Nanoparticles in photodynamic therapy: An emerging paradigm, Advanced Drug Delivery Reviews, v. 60, p. 1627-1637, 2008.

CHAUSSAIN-MILLER, C.; SEPTIER, D.; BONNEFOIX, M.; LECOLLE, S.; LEBRETONDECOSTER, C.; COULOMB, B.; PELLAT, B.; GODEAU, G. Human dermal and gingival fibroblasts in a three-dimensional culture: a comparative study on matrix remodeling, Clinical Oral Investigation, v. 6, p. 39-50, 2002.

CHEN, H. B.; KHEMTONG, C.; YANG, X. L.; CHANG, X. L.; GAO, J. M. Nanonization strategies for poorly water-soluble drugs, Drug Discovery Today, v. 16, p. 354-360, 2011.

CHEN, J.; GAN, Q.; LI, S. Y.; GONG, F. B.; WANG, Q.; YANG, Z. P.; WANG, S. Q.; XU, H. J.; MA, J. S.; YANG, G. Q. The effects of central metals and peripheral substituents on the photophysical properties and optical limiting performance of phthalocyanines with axial chloride ligand, Journal of Photochemistry and Photobiology A-Chemistry, v. 207, p. 5865, 2009.

CLARIDGE, E.; COTTON, S.; HALL, P.; MONCRIEFF, M. From colour to tissue histology: Physics-based interpretation of images of pigmented skin lesions, Medical Image Analysis, v. 7, p. 489-502, 2003.

CLARK, R. A. F. Biology of Dermal Wound Repair, Dermatologic Clinics, v. 11, p. 647666, 1993.

COLIC, M. M.; VIDOJKOVIC, N.; JOVANOVIC, M.; LAZOVIC, G. The use of polarized light in aesthetic surgery, Aesthetic Plastic Surgery, v. 28, p. 324-327, 2004.

COULOMB, B.; DUBERTRET, L. Skin cell culture and wound healing, Wound Repair and Regeneration, v. 10, p. 109-112, 2002.

COULOMB, B.; DUBERTRET, L.; BELL, E.; MERRILL, C.; FOSSE, M.;

BRETONGORIUS, J.; PROST, C.; TOURAINE, R. Endogenous Peroxidases in Normal Human Dermis - A Marker of Fibroblast Differentiation, Journal of Investigative

Dermatology, v. 81, p. 75-78, 1983.

COUSSENS, L. M.; FINGLETON, B.; MATRISIAN, L. M. Cancer therapy - Matrix metalloproteinase inhibitors and cancer: Trials and tribulations, Science, v. 295, p. 23872392, 2002.

DAMODHARAN, U.; GANESAN, R.; RADHAKRISHNAN, U. C. Expression of MMP2 and MMP9 (Gelatinases A and B) in Human Colon Cancer Cells, Applied Biochemistry and Biotechnology, v. 165, p. 1245-1252, 2011.

DAMS, S. D.; LIEFDE-VAN BEEST, M.; NUIJS, A. M.; OOMENS, C. W. J.; BAAIJENS, F. P. T. Heat shocks enhance procollagen type I and III expression in fibroblasts in ex vivo human skin, Skin Research and Technology, v. 17, p. 167-180, 2011. 
DOUGHERTY, T. J. Photodynamic Therapy (Pdt) of Malignant-Tumors, Crc Critical Reviews in Oncology/Hematology, v. 2, p. 83-116, 1984.

DOUGHERTY, T. J.; GRINDEY, G. B.; FIEL, R.; WEISHAUPT, K. R.; BOYLE, D. G. Photoradiation Therapy .2. Cure of Animal Tumors with Hematoporphyrin and Light, Journal of the National Cancer Institute, v. 55, p. 115-121, 1975.

EL FAHIME, E.; TORRENTE, Y.; CARON, N. J.; BRESOLIN, M. D.; TREMBLAY, J. P. In vivo migration of transplanted myoblasts requires matrix metalloproteinase activity, Experimental Cell Research, v. 258, p. 279-287, 2000.

FALQUEIRO, A. M. Nanocápsulas contendo selol e fluído magnético: preparação, caracterização e avaliação da atividade antitumoral in vitro. Dissertação de Mestrado Faculdade de Ciências Farmacêuticas de Ribeirão Preto - USP, Ribeirão Preto - SP, 2011.

FERREIRA, D. M. Estudos de sistemas nanocarreadores para o ácido 5- aminolevulínico (5-ALA) e seu éster derivado (8- ALA) aplicados na Eletroquimioterapia e Terapia Fotodinâmica contra câncer de pele. Tese de Doutorado - Faculdade de Ciências Farmacêuticas de Ribeirão Preto - USP, Ribeirão Preto, 2012.

GARCIA, V. G.; DE LIMA, M. A.; OKAMOTO, T.; MILANEZI, L. A.; GUALBERTO, E. C.; FERNANDES, L. A.; DE ALMEIDA, J. M.; THEODORO, L. H. Effect of photodynamic therapy on the healing of cutaneous third-degree-burn: histological study in rats, Lasers in Medical Science, v. 25, p. 221-228, 2010.

GOLINSKI, P. A.; GROGER, S.; HERRMANN, J. M.; BERND, A.; MEYLE, J. Oral mucosa model based on a collagen-elastin matrix, Journal of Periodontal Research, v. 46, p. 704-711, 2011.

GOMES, A. J. Obtenção, caracterização e avalaliação de micropartículas de PLGA contendo indocianina e bacterioclorofila-a como sistemas de liberação de fármacos na terapia fotodinâmica. Tese de Doutorado - Faculdade de Filosofia, Ciências e Letras de Ribeirão Preto - SP, Ribeirão Preto - SP, 2003.

GRIESHABER, S. E.; FARRAN, A. J. E.; BAI, S.; KIICK, K. L.; JIA, X. Q. Tuning the Properties of Elastin Mimetic Hybrid Copolymers via a Modular Polymerization Method, Biomacromolecules, v. 13, p. 1774-1786, 2012.

GUNDIAH, N.; RATCLIFFE, M. B.; PRUITT, L. A. Determination of strain energy function for arterial elastin: Experiments using histology and mechanical tests, Journal of Biomechanics, v. 40, p. 586-594, 2007.

GUNGORMUS, M.; AKYOL, U. K. Effect of Biostimulation on Wound Healing in Diabetic Rats, Photomedicine and Laser Surgery, v. 27, p. 607-610, 2009.

HAMIDI, M.; AZADI, A.; RAFIEI, P. Hydrogel nanoparticles in drug delivery, Advanced Drug Delivery Reviews, v. 60, p. 1638-1649, 2008.

HU, W. P.; WANG, J. J.; YU, C. L.; LAN, C. C. E.; CHEN, G. S.; YU, H. S. Helium-neon laser irradiation stimulates cell proliferation through photostimulatory effects in mitochondria, Journal of Investigative Dermatology, v. 127, p. 2048-2057, 2007. 
HUGHES, G. A. Nanostructure-mediated drug delivery, Dm Disease-A-Month, v. 51, p. 342-361, 2005.

JAYASREE, R. S.; GUPTA, A. K.; RATHINAM, K.; MOHANAN, P. V.; MOHANTY, M. The influence of photodynamic therapy on the wound healing process in rats, Journal of Biomaterials Applications, v. 15, p. 176-186, 2001.

JENNING, V.; SCHAFER-KORTING, M.; GOHLA, S. Vitamin A-loaded solid lipid nanoparticles for topical use drug release properties, Journal of Controlled Release, v. 66, p. 115-126, 2000.

JUNQUEIRA, L. C.; CARNEIRO, J. Histologia Básica 10 ed., Ed. Guanabara Koogan, 2004.

KARU, T. I. Molecular mechanism of the therapeutic effect of low-intensity laser radiation, Laser in the Life Sciences, v. 2, p. 53-74, 1988.

KARU, T. I.; KOLYAKOV, S. F. Exact action spectra for cellular responses relevant to phototherapy, Photomedicine and Laser Surgery, v. 23, p. 355-361, 2005.

KIRILOV, P.; LUKYANOVA, L.; FRANCESCHI-MESSANT, S.; PERIER, V.; PEREZ, E.; RICO-LATTES, I. A new type of colloidal dispersions based on nanoparticles of gelled oil, Colloids and Surfaces A-Physicochemical and Engineering Aspects, v. 328, p. 1-7, 2008.

KONAN, Y. N.; GURNY, R.; ALLEMANN, E. State of the art in the delivery of photosensitizers for photodynamic therapy, Journal of Photochemistry and Photobiology BBiology, v. 66, p. 89-106, 2002.

LAVI, R.; SHAINBERG, A.; FRIEDMANN, H.; SHNEYVAYS, V.; RICKOVER, O.; EICHLER, M.; KAPLAN, D.; LUBART, R. Low energy visible light induces reactive oxygen species generation and stimulates an increase of intracellular calcium concentration in cardiac cells, Journal of Biological Chemistry, v. 278, p. 40917-40922, 2003.

LELONGT, B.; TRUGNAN, G.; MURPHY, G.; RONCO, P. M. Matrix metalloproteinases MMP2 and MMP9 are produced in early stages of kidney morphogenesis but only MMP9 is required for renal organogenesis in vitro, Journal of Cell Biology, v. 136, p. 1363-1373, 1997.

LENAERTS, V.; LABIB, A.; CHOUINARD, F.; ROUSSEAU, J.; ALI, H.; VANLIER, J. Nanocapsules with A Reduced Liver Uptake - Targeting of Phthalocyanines to Emt-6 Mouse Mammary-Tumor In-Vivo, European Journal of Pharmaceutics and Biopharmaceutics, v. 41, p. 38-43, 1995.

LIPSON, R. L.; BALDES, E. J.; OLSEN, A. M. Use of A Derivative of Hematoporphyrin in Tumor Detection, Journal of the National Cancer Institute, v. 26, p. 1-\&, 1961.

LUBART, R.; EICHLER, M.; LAVI, R.; FRIEDMAN, H.; SHAINBERG, A. Low-energy laser irradiation promotes cellular redox activity, Photomedicine and Laser Surgery, v. 23, p. 3-9, 2005. 
LUNARDI, C. N.; ROTTA, J. C. G.; TEDESCO, A. C. Synthesis, photophysical and photobiological study of synergic photosensitizer: Zinc-phthalocyanine with $\mathrm{Ca} 2+$ chelating agent, Current Organic Chemistry, v. 11, p. 647-654, 2007.

MACAROFF, P. P.; PRIMO, F. L.; DE AZEVEDO, R. B.; LACAVA, Z. G. M.; MORAIS, P. C.; TEDESCO, A. C. Synthesis and characterization of a magnetic nanoemulsion as a promising candidate for cancer treatment, Ieee Transactions on Magnetics, v. 42, p. 35963598, 2006.

MCCAWLEY, L. J.; MATRISIAN, L. M. Matrix metalloproteinases: they're not just for matrix anymore!, Current Opinion in Cell Biology, v. 13, p. 534-540, 2001.

MESTER, E.; SPIRY, T.; SZENDE, B.; TOTA, J. G. Effect of Laser Rays on Wound Healing, American Journal of Surgery, v. 122, p. 532-\&, 1971.

MITTS, T. F.; BUNDA, S.; WANG, Y. T.; HINEK, A. Aldosterone and Mineralocorticoid Receptor Antagonists Modulate Elastin and Collagen Deposition in Human Skin, Journal of Investigative Dermatology, v. 130, p. 2396-2406, 2010.

MOULIN, V.; AUGER, F. A.; GARREL, D.; GERMAIN, L. Role of wound healing myofibroblasts on re-epithelialization of human skin, Burns, v. 26, p. 3-12, 2000.

NAVEAU, A.; REINALD, N.; FOURNIER, B.; DURAND, E.; LAFONT, A.; COULOMB, B.; GOGLY, B. Gingival fibroblasts inhibit MMP-1 and MMP-3 activities in an Ex-vivo artery model, Connective Tissue Research, v. 48, p. 300-308, 2007.

NELSON, K. K.; MELENDEZ, J. A. Mitochondrial redox control of matrix metalloproteinases, Free Radical Biology and Medicine, v. 37, p. 768-784, 2004.

NUNES, S. M. T. Uso Potencial de LDE e Microesferas de Albumina como sistemas liberadores de ftalocianinas e clorinas ativas na Terapia Fotodinâmica de neoplasias. Dissertação de Mestrado - Faculdade de Filosofia, Ciências e Letras de Ribeirão Preto -USP, Ribeirão Preto - SP, 2000.

NUNES, S. M. T. A potencialidade do uso de diferentes sistemas de liberação de fármacos na Terapia Fotodinâmica: Preparação e estudos Fotofísicos. Tese de Doutorado - Faculdade de Filosofia, Ciências e Letras de Ribeirão Preto -USP, Ribeirão Preto - SP, 2003.

NUNES, S. M. T.; SGUILLA, F. S.; TEDESCO, A. C. Photophysical studies of zinc phthalocyanine and chloroaluminum phthalocyanine incorporated into liposomes in the presence of additives, Brazilian Journal of Medical and Biological Research, v. 37, p. 273 284, 2004.

ODLAND, G.; ROSS, R. Human Wound Repair .1. Epidermal Regeneration, Journal of Cell Biology, v. 39, p. 135-\&, 1968.

OLIVEIRA, A. G.; SCARPA.M.V.; CORREA, M. A.; CERA, L. F. R.; FORMARIZ, T. P. Microemulsões: estrutura e aplicações como sistema de liberação de fármacos, Química Nova, v. 27, p. 131-138, 2003. 
OLIVEIRA, D. M.; MACAROFF, P. P.; RIBEIRO, K. F.; LACAVA, Z. G. M.; AZEVEDO, R. B.; LIMA, E. C. D.; MORAIS, P. C.; TEDESCO, A. C. Studies of zinc phthalocyanine/magnetic fluid complex as a bifunctional agent for cancer treatment, Journal of Magnetism and Magnetic Materials, v. 289, p. 476-479, 2005.

PAGANO, M. Application of electrophoresis and related methods, such as western blotting and zymography to the study of some proteins and enzymes, Analytica Chimica Acta, v. 383, p. 119-125, 1999.

PAL, G.; DUTTA, A.; MITRA, K.; GRACE, M. S.; AMAT, A.; ROMANCZYK, T. B.; WU, X. J.; CHAKRABARTI, K.; ANDERS, J.; GORMAN, E.; WAYNANT, R. W.; TATA, D. B. Effect of low intensity laser interaction with human skin fibroblast cells using fiber-optic nano-probes, Journal of Photochemistry and Photobiology B-Biology, v. 86, p. 252-261, 2007.

PARK, J. H.; MOON, Y. H.; BANG, I. S.; KIM, Y. C.; KIM, S. A.; AHN, S. G.; YOON, J. H. Antimicrobial effect of photodynamic therapy using a highly pure chlorin e6, Lasers in Medical Science, v. 25, p. 705-710, 2010.

PASZKO, E.; EHRHARDT, C.; SENGE, M. O.; KELLEHER, D. P.; REYNOLDS, J. V. Nanodrug applications in photodynamic therapy, Photodiagnosis and Photodynamic Therapy, v. 8, p. 14-29, 2011.

PATRI, A. K.; MAJOROS, I. J.; BAKER, J. R. Dendritic polymer macromolecular carriers for drug delivery, Current Opinion in Chemical Biology, v. 6, p. 466-471, 2002.

PAZOS, M. D. C.; NADER, H. B. Effect of photodynamic therapy on the extracellular matrix and associated components, Brazilian Journal of Medical and Biological Research, v. 40, p. 1025-1035, 2007.

PEPLOW, P. V.; CHUNG, T. Y.; BAXTER, G. D. Photodynamic Modulation of Wound Healing: A Review of Human and Animal Studies, Photomedicine and Laser Surgery, v. 30, p. 118-148, 2012.

PRIMO, F. L. Processos fotodinâmicos para bioestimulação tecidual em modelo in vitro de pele humana empregando-se laser de baixa potência e cloro alumínio ftalocianina em nanoemulsão. Tese de Doutorado - Faculdade de Ciências Farmacêuticas de Ribeirão Preto USP, Ribeirão Preto - SP, 2009.

PRIMO, F. L.; REIS, M. B. D.; PORCIONATTO, M. A.; TEDESCO, A. C. In Vitro Evaluation of Chloroaluminum Phthalocyanine Nanoemulsion and Low-Level Laser Therapy on Human Skin Dermal Equivalents and Bone Marrow Mesenchymal Stem Cells, Current Medicinal Chemistry, v. 18, p. 3376-3381, 2011.

PRIMO, F. L.; RODRIGUES, M. M. A.; SIMIONI, A. R.; BENTLEY, M. V. L. B.; MORAIS, P. C.; TEDESCO, A. C. In vitro studies of cutaneous retention of magnetic nanoemulsion loaded with zinc phthalocyanine for synergic use in skin cancer treatment, Journal of Magnetism and Magnetic Materials, v. 320, p. E211-E214, 2008. 
PRIMO, F. L.; SIQUEIRA-MOURA, M. P.; SIMIONI, A. R.; PETI, A. P. F.; TEDESCO, A. C. Preparation, characterization and citotoxicity assays of chloroaluminum phthalocyanine photosensitizer drug loaded in PLGA-nanocapsules, Drugs of the Future, v. 32, p. 74, 2007.

RIEKKI, R.; JUKKOLA, A.; SASSI, M. L.; HOYHTYA, M.; KALLIOINEN, M.; RISTELI, J.; OIKARINEN, A. Modulation of skin collagen metabolism by irradiation: collagen synthesis is increased in irradiated human skin, British Journal of Dermatology, v. 142, p. 874-880, 2000.

ROCHA, J. C. T. Terapia Laser, cicatrização tecidual e angiogenese, $\boldsymbol{R B P S}$, v. 17, p. 44-48, 2004.

SARIKAYA, M.; TAMERLER, C.; JEN, A. K. Y.; SCHULTEN, K.; BANEYX, F. Molecular biomimetics: nanotechnology through biology, Nature Materials, v. 2, p. 577 $585,2003$.

SHARWANI, A.; JERJES, W.; HOPPER, C.; LEWIS, M. P.; EL-MAAYTAH, M.; KHALIL, H. S. M.; MACROBERT, A. J.; UPILE, T.; SALIH, V. Photodynamic therapy downregulates the invasion promoting factors in human oral cancer, Archives of Oral Biology, v. 51, p. 1104-1111, 2006.

SHIM, J.; KANG, H. S.; PARK, W. S.; HAN, S. H.; KIM, J.; CHANG, I. S. Transdermal delivery of mixnoxidil with block copolymer nanoparticles, Journal of Controlled Release, v. 97, p. 477-484, 2004.

SHIN, M. H.; RHIE, G. E.; PARK, C. H.; KIM, K. H.; CHO, K. H.; EUN, H. C.; CHUNG, J. $\mathrm{H}$. Modulation of collagen metabolism by the topical application of dehydroepiandrosterone to human skin, Journal of Investigative Dermatology, v. 124, p. 315-323, 2005.

SHOULDERS, M. D.; RAINES, R. T. Collagen Structure and Stability, Annual Review of Biochemistry, v. 78, p. 929-958, 2009.

SILVA, A. R. A.; SIMIONI, A. R.; TEDESCO, A. C. Photophysical and Complexation Studies of Chloro-Aluminum Phthalocyanine with Beta-Cyclodextrin and HydroxypropylBeta-Cyclodextrin, Journal of Nanoscience and Nanotechnology, v. 11, p. 4046-4055, 2011.

SIMIONI, A. R. Estudos de silício-naftaloftalocianina como agente potencialmente ativo na terapia fotodinâmica de neoplasias cutâneas e sistêmicas. Tese de Doutorado Faculdade de Filosofia, Ciências e Letras de Ribeirão Preto - USP, Ribeirão Preto - SP, 2009.

SIMIONI, A. R.; COULOMB, B.; COUTY, L.; TEDESCO, A. C. Photodynamic Therapy Preserves Elastic Network from Degradation in An Ex Vivo Human Skin Model, Wound Repair and Regeneration, v. 17, p. A80, 2009.

SIPOS, P.; GYORY, H.; HAGYMASI, K.; ONDREJKA, P.; BLAZOVICS, A. Special wound healing methods used in ancient Egypt and the mythological background, World Journal of Surgery, v. 28, p. 211-216, 2004. 
SIQUEIRA-MOURA, M. P. Nanocarreadores contendo ftalocianina de cloroalumínio: desenvolvimento, caracterização físico-química e avaliação in vitro da fotocitotoxicidade em melanoma. Tese de Doutorado - Faculdade de Ciências Farmacêuticas de Ribeirão Preto USP, Ribeirão Preto - SP, 2011.

SIQUEIRA-MOURA, M. P.; PRIMO, F. L.; PETI, A. P. F.; TEDESCO, A. C. Validated spectrophotometric and spectrofluorimetric methods for determination of chloroaluminum phthalocyanine in nanocarriers, Pharmazie, v. 65, p. 9-14, 2010.

SITNIK, T. M.; HENDERSON, B. W. The effect of fluence rate on tumor and normal tissue responses to photodynamic therapy, Photochemistry and Photobiology, v. 67, p. 462-466, 1998.

SOBOLEV, A. S.; JANS, D. A.; ROSENKRANZ, A. A. Targeted intracellular delivery of photosensitizers, Progress in Biophysics \& Molecular Biology, v. 73, p. 51-90, 2000.

SOPPIMATH, K. S.; AMINABHAVI, T. M.; KULKARNI, A. R.; RUDZINSKI, W. E. Biodegradable polymeric nanoparticles as drug delivery devices, Journal of Controlled Release, v. 70, p. 1-20, 2001.

SOUSSAN, E.; CASSEL, S.; BLANZAT, M.; RICO-LATTES, I. Drug Delivery by Soft Matter: Matrix and Vesicular Carriers, Angewandte Chemie-International Edition, v. 48, p. 274-288, 2009.

STERNLICHT, M. D.; WERB, Z. How matrix metalloproteinases regulate cell behavior, Annual Review of Cell and Developmental Biology, v. 17, p. 463-516, 2001.

SZEIMIES, R. M.; TOREZAN, L.; NIWA, A.; VALENTE, N.; UNGER, P.; KOHL, E.; SCHREML, S.; BABILAS, P.; KARRER, S.; FESTA-NETO, C. Clinical, histopathological and immunohistochemical assessment of human skin field cancerization before and after photodynamic therapy, British Journal of Dermatology, v. 167, p. 150-159, 2012.

TAMIETTI, B. F. P.; MACHADO, A. H. A.; MAFTOUM-COSTA, M.; DA SILVA, N. S.; TEDESCO, A. C.; PACHECO-SOARES, C. Analysis of mitochondrial activity related to cell death after PDT with AlPCS4, Photomedicine and Laser Surgery, v. 25, p. 175-179, 2007.

TEDESCO, A. C.; ROTTA, J. C. G.; LUNARDI, C. N. Synthesis, photophysical and photochemical aspects of phthalocyanines for photodynamic therapy, Current Organic Chemistry, v. 7, p. 187-196, 2003.

TRAUNER, K. B.; HASAN, T. Photodynamic treatment of rheumatoid and inflammatory arthritis, Photochemistry and Photobiology, v. 64, p. 740-750, 1996.

VALENTI, D. M. Z.; SILVA, J.; TEODORO, W. R.; VELOSA, A. P.; MELLO, S. B. V. Effect of topical clay application on the synthesis of collagen in skin: an experimental study, Clinical and Experimental Dermatology, v. 37, p. 164-168, 2012.

VAN DEN STEEN, P. E.; OPDENAKKER, G.; WORMALD, M. R.; DWEK, R. A.; RUDD, P. M. Matrix remodelling enzymes, the protease cascade and glycosylation, Biochimica et Biophysica Acta-General Subjects, v. 1528, p. 61-73, 2001. 
YANIK, H.; AYDIN, D.; DURMUS, M.; AHSEN, V. Peripheral and non-peripheral tetrasubstituted aluminium, gallium and indium phthalocyanines: Synthesis, photophysics and photochemistry, Journal of Photochemistry and Photobiology A-Chemistry, v. 206, p. 1826, 2009.

ZANCANELA, D. C.; PRIMO, F. L.; ROSA, A. L.; CIANCAGLINI, P.; TEDESCO, A. C. The Effect of Photosensitizer Drugs and Light Stimulation on Osteoblast Growth, Photomedicine and Laser Surgery, v. 29, p. 699-705, 2011.

ZHANG, Y. O.; SONG, S. P.; FONG, C. C.; TSANG, C. H.; YANG, Z.; YANG, M. S. CDNA microarray analysis of gene expression profiles in human fibroblast cells irradiated with red light, Journal of Investigative Dermatology, v. 120, p. 849-857, 2003. 